Prepared in cooperation with the Michigan Department of Environmental Quality

\title{
Temporal Trends in Water-Quality Constituent Concentrations and Annual Loads of Chemical Constituents in Michigan Watersheds, 1998-2013
}

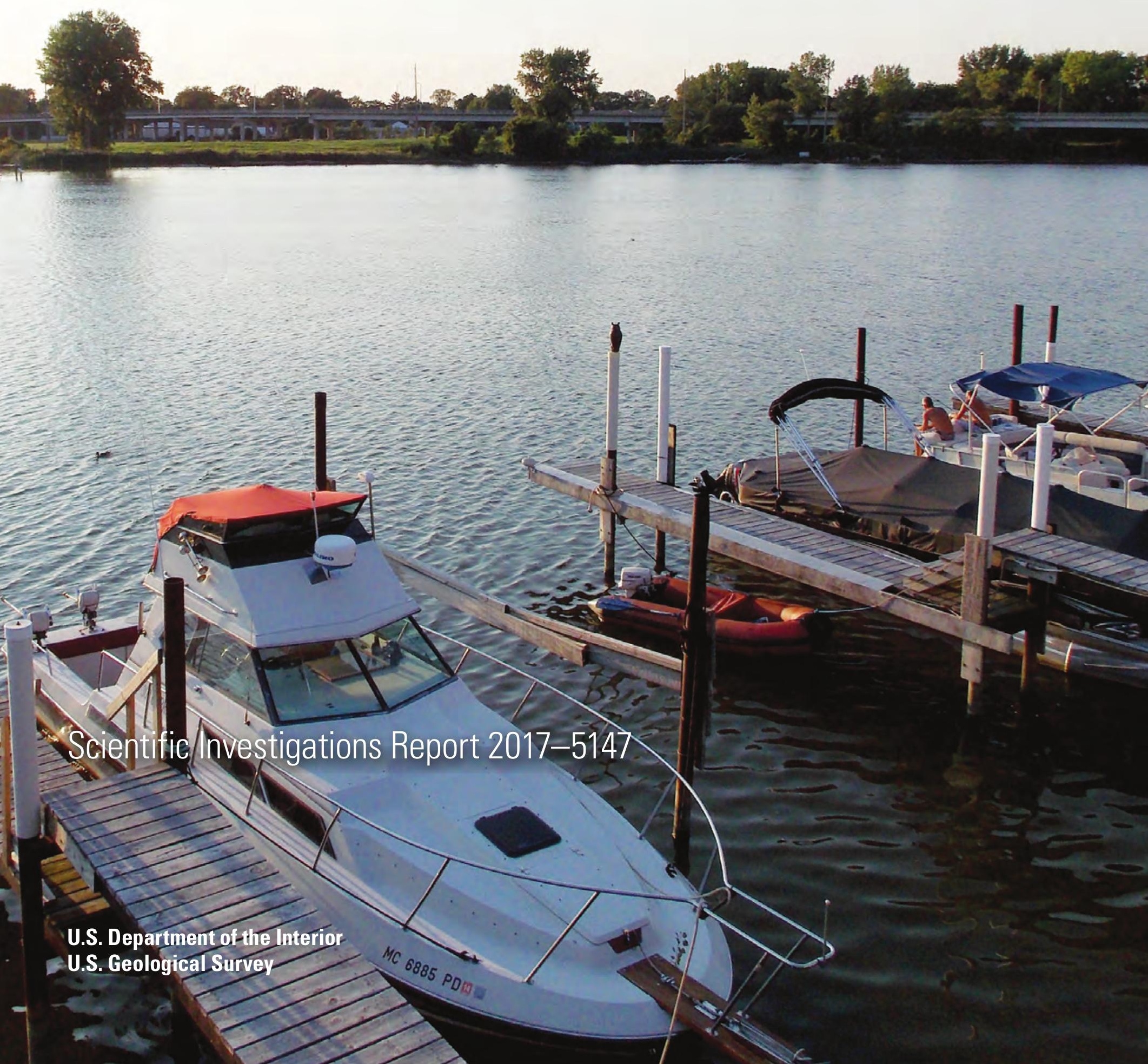


Cover. Saginaw River near Bay City upstream from U.S. Geological Survey station 04157065. Photograph by Aaron Toth. 


\section{Temporal Trends in Water-Quality Constituent Concentrations and Annual Loads of Chemical Constituents in Michigan Watersheds, 1998-2013}

By Christopher J. Hoard, Lisa Reynolds Fogarty, and Joseph W. Duris

Prepared in cooperation with the Michigan Department of Environmental Quality

Scientific Investigations Report 2017-5147 


\title{
U.S. Department of the Interior \\ RYAN K. ZINKE, Secretary
}

\section{U.S. Geological Survey William H. Werkheiser, Deputy Director exercising the authority of the Director}

\author{
U.S. Geological Survey, Reston, Virginia: 2018
}

For more information on the USGS - the Federal source for science about the Earth, its natural and living resources, natural hazards, and the environment-visit https://www.usgs.gov or call 1-888-ASK-USGS.

For an overview of USGS information products, including maps, imagery, and publications, visit https://store.usgs.gov.

Any use of trade, firm, or product names is for descriptive purposes only and does not imply endorsement by the U.S. Government.

Although this information product, for the most part, is in the public domain, it also may contain copyrighted materials as noted in the text. Permission to reproduce copyrighted items must be secured from the copyright owner.

Suggested citation:

Hoard, C.J., Fogarty, L.R., and Duris, J.W., 2018, Temporal trends in water-quality constituent concentrations and annual loads of chemical constituents in Michigan watersheds, 1998-2013: U.S. Geological Survey Scientific Investigations Report 2017-5147, 79 p., https://doi.org/10.3133/sir20175147.

ISSN 2328-031X (print)

ISSN 2328-0328 (online) 


\section{Contents}

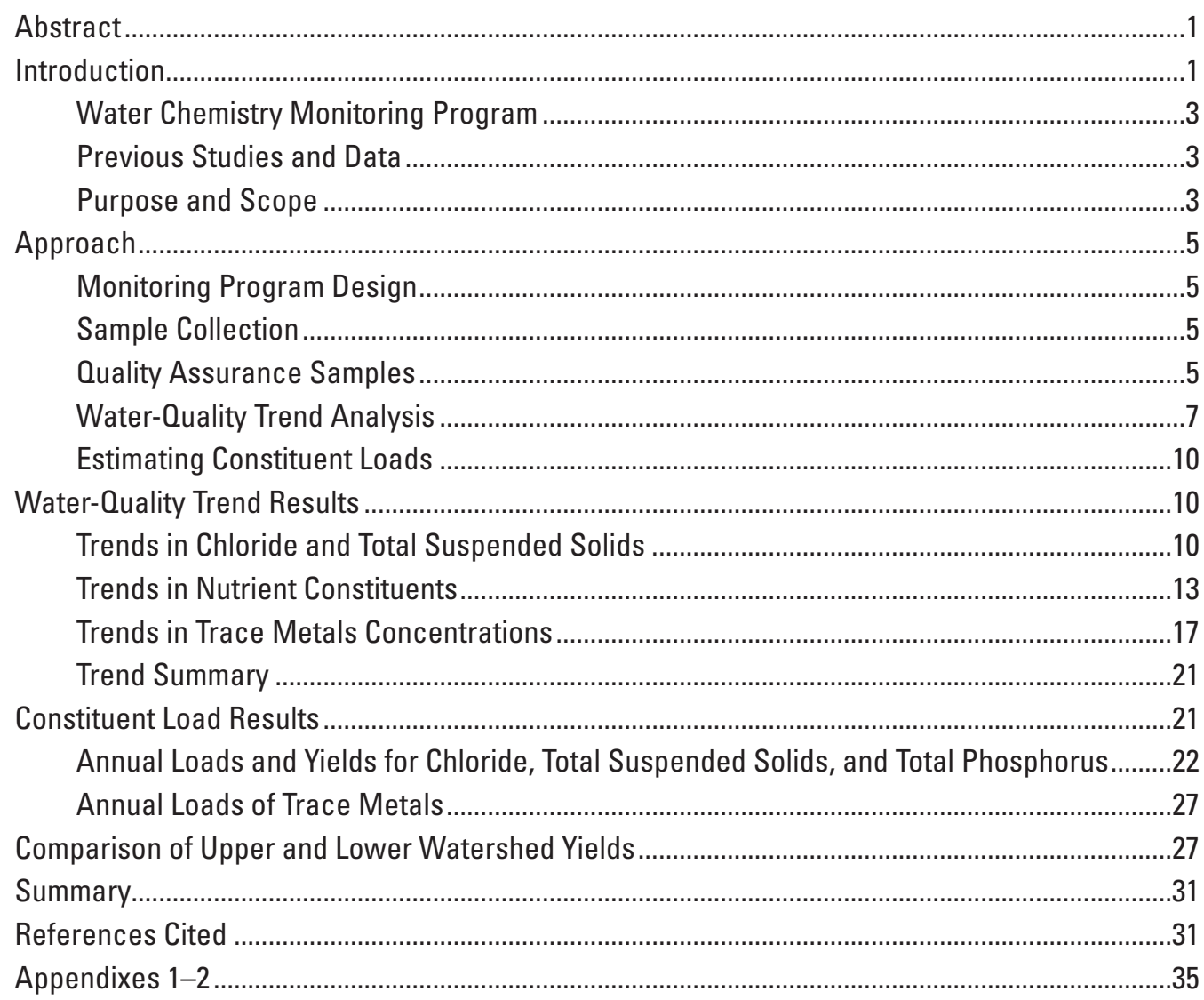

\section{Figures}

1. Map showing Michigan watersheds and associated land cover studied as part of the Michigan Water Chemistry Monitoring Program ...................................................2

2. Maps showing trend results for chloride, total suspended solids, total phosphorus, and orthophosphate by Michigan watershed..

3. Maps showing trend results for ammonia, nitrate, nitrite, and total Kjeldahl nitrogen by Michigan watershed

4. Maps showing trend results for chromium, copper, lead, and mercury by Michigan watershed

5. Graph showing number of upward and downward trends at Michigan stream stations

6. Graphs showing annual total phosphorus loads and yields for six intensively monitored rivers, 2002-13. 
7. Graphs showing annual total suspended solids and yields for six intensively monitored rivers, 2002-13..

8. Graphs showing annual chloride loads and yields for six intensively monitored rivers, 2002-13.

9 Graph showing annual average streamflow for six intensively monitored rivers, 2002-13

10. Graph showing comparison of chloride, total suspended solids, and total phosphorus

yields for lower and upper watershed sampling locations...

\section{Tables}

1. Stations sampled as part of the Michigan Water Chemistry Monitoring Program ...........4

2. Michigan Water Chemistry Monitoring Program distribution of samples over time by station, 1998-2013.

3. Summary of quality control field blank samples collected for the Water Chemistry Monitoring Program.

4. Summary of quality control replicate samples for the Water Chemistry Monitoring Program.

5 U.S. Geological Survey station information and years for which annual loads were produced

6. U.S. Geological Survey stations used in the Water Chemistry Monitoring Program load computation

7. Composite summary of constituent concentration data collected for the Water Chemistry Monitoring Program 1998-2013.

8 Trend results for chloride and total suspended solids at Michigan stream stations, 1999-2013

9. Trend results for select nutrient constituents at Michigan stream stations, 1999-2013

10. Trend results for trace metal constituents at Michigan stream stations, 1999-2013

11. Water Chemistry Monitoring Program load and yield summary statistics for chloride, total suspended solids, and total phosphorus at intensively monitored stations, 2002-13.

12. Water Chemistry Monitoring Program load and yield summary statistics for cooper, chromium, lead, and mercury at intensively monitored stations, 2002-13

\section{Appendix Tables}

1. Summary of data collected at select Michigan Water-Chemistry Monitoring Program stream sites, 1999-2013.

2. Loads for Water Chemistry Monitoring Program by site, constituent, and year. 


\section{Conversion Factors}

International System of Units to U.S. customary units

\begin{tabular}{lcl}
\hline & Bultiply & To obtain \\
\hline meter $(\mathrm{m})$ & Length & foot $(\mathrm{ft})$ \\
\hline & 3.281 & \\
\hline square kilometer $\left(\mathrm{km}^{2}\right)$ & Area & square mile $\left(\mathrm{mi}^{2}\right)$ \\
\hline & 0.3861 & \\
\hline liter $(\mathrm{L})$ & Volume & ounce, fluid $(\mathrm{fl} . \mathrm{oz})$ \\
liter $(\mathrm{L})$ & 33.81402 & pint (pt) \\
liter $(\mathrm{L})$ & 2.113 & quart (qt) \\
liter $(\mathrm{L})$ & 1.057 & gallon (gal) \\
\hline & 0.2642 & \\
\hline cubic meter per second $\left(\mathrm{m}^{3} / \mathrm{s}\right)$ & Flow rate & cubic foot per second $\left(\mathrm{ft}{ }^{3} / \mathrm{s}\right)$ \\
\hline
\end{tabular}

Temperature in degrees Celsius $\left({ }^{\circ} \mathrm{C}\right)$ may be converted to degrees Fahrenheit $\left({ }^{\circ} \mathrm{F}\right)$ as follows:

$$
{ }^{\circ} \mathrm{F}=\left(1.8 \times{ }^{\circ} \mathrm{C}\right)+32 .
$$

U.S. customary units to International System of Units

\begin{tabular}{lcl}
\hline & Multiply & By obtain \\
\hline foot $(\mathrm{ft})$ & Length & meter $(\mathrm{m})$ \\
\hline & 0.3048 & \\
\hline square mile $\left(\mathrm{mi}^{2}\right)$ & Area & square kilometer $\left(\mathrm{km}^{2}\right)$ \\
\hline & 2.590 & \\
\hline ounce, fluid $(\mathrm{fl} . \mathrm{oz})$ & Volume & liter $(\mathrm{L})$ \\
pint $(\mathrm{pt})$ & 0.02957 & liter $(\mathrm{L})$ \\
quart (qt) & 0.4732 & liter $(\mathrm{L})$ \\
gallon (gal) & 0.9464 & liter $(\mathrm{L})$ \\
\hline & 3.785 & \\
\hline cubic foot per second $\left(\mathrm{ft}{ }^{3} / \mathrm{s}\right)$ & Flow rate & cubic meter per second $\left(\mathrm{m}{ }^{3} / \mathrm{s}\right)$ \\
\hline
\end{tabular}

Temperature in degrees Fahrenheit $\left({ }^{\circ} \mathrm{F}\right)$ may be converted to degrees Celsius $\left({ }^{\circ} \mathrm{C}\right)$ as follows:

$$
{ }^{\circ} \mathrm{C}=\left({ }^{\circ} \mathrm{F}-32\right) / 1.8 \text {. }
$$




\title{
Supplemental Information
}

Concentrations of chemical constituents in water are given in either milligrams per liter $(\mathrm{mg} / \mathrm{L})$, micrograms per liter $(\mu \mathrm{g} / \mathrm{L})$, or nanograms per liter (ng/L).

\section{Abbreviations}

\author{
MDEO Michigan Department of Environmental Quality \\ TKN total Kjeldahl nitrogen \\ TSS total suspended solids \\ USGS U.S. Geological Survey \\ WCMP Water Chemistry Monitoring Program
}




\title{
Temporal Trends in Water-Quality Constituent Concentrations and Annual Loads of Chemical Constituents in Michigan Watersheds, 1998-2013
}

\author{
By Christopher J. Hoard, Lisa R. Fogarty, and Joseph W. Duris
}

\section{Abstract}

In 1998, the Michigan Department of Environmental Quality and the U.S. Geological Survey began the Water Chemistry Monitoring Program for select streams in the State of Michigan. Objectives of this program were to provide assistance with (1) statewide water-quality assessments, (2) the National Pollutant Discharge Elimination System permitting process, and (3) water-resource management decisions. As part of this program, water-quality data collected from 1998 to 2013 were analyzed to identify potential trends for select constituents that were sampled. Sixteen water-quality constituents were analyzed at 32 stations throughout Michigan. Trend analysis on the various water-quality data was done using either the uncensored Seasonal Kendall test or through Tobit regression. In total, 79 trends were detected in the constituents analyzed for 32 river stations sampled for the study period -53 downward trends and 26 upward trends were detected. The most prevalent trend detected throughout the State was for ammonia, with 11 downward trends and 1 upward trend estimated.

In addition to trends, constituent loads were estimated for 31 stations from 2002 to 2013 for stations that were sampled 12 times per year. Loads were computed using the Autobeale load computation program, which used the Beale ratio estimator approach to estimate an annual load. Constituent loads were the largest in large watershed streams with the highest annual flows such as the Saginaw and Grand Rivers. Likewise, constituent loads were the smallest in smaller tributaries that were sampled as part of this program such as the Boardman and Thunder Bay Rivers.

\section{Introduction}

The surface water in Michigan and the surrounding Great Lakes is an important ecological, recreational, and economical resource. Michigan has 36,350 miles of rivers and streams that drain 62 major watersheds to the Great Lakes. The importance of these waters to the State of Michigan and Great Lakes was acknowledged in 1998, with the passage of the Clean Michigan Initiative by the citizens of Michigan. This initiative authorized \$675 million in State bonds to finance environmental and natural resources protection programs.

Beginning in 1998, the U.S. Geological Survey (USGS)

Michigan Water Science Center, in cooperation with the Michigan Department of Environmental Quality (MDEQ), collected samples for water quality from tributaries throughout Michigan (fig. 1) as part of the MDEQ Water Chemistry Monitoring Program (WCMP). Supported by the Clean Michigan Initiative, this long-term monitoring program was designed to assess the quality of Michigan rivers and streams that drain to the Great Lakes and to determine if the chemical characteristics of surface waters of the State are changing with time.

The WCMP used a two-phase approach. Initially, the WCMP helped to establish baseline water quality for rivers and streams. Once baseline water quality was established, continued monitoring allowed for the assessment of trends of water-quality constituents. This type of monitoring program can help identify the need for remediation or changes in management practices and also help determine the effects that changes to prior water or land-management practices have had on water quality. Changes in water quality of a river or stream can be the result of several factors; for example, land-use change, population growth, water use, and climate change.

As part of the WCMP, sampling for determination of constituent loads followed the same two-phase sampling approach as was used to identify trends. The product of a constituent concentration and the volume of water during a defined period of time is referred to as the load of the constituent. Constituent loads are often estimated on an annual or monthly basis and are important when determining the potential impact constituents may have on the environment. Understanding constituent loads is important when evaluating the potential ecological and biological impacts to receiving waters and, ultimately, to the Great Lakes. For example, an intense focus has been on understanding the total load of phosphorus to Lake Erie (not shown), which has had harmful algal blooms of increasing frequency, magnitude, and duration since the middle 1990s (International Joint Commission, 2014). The total load of phosphorus to Lake Erie has been identified as one of the 


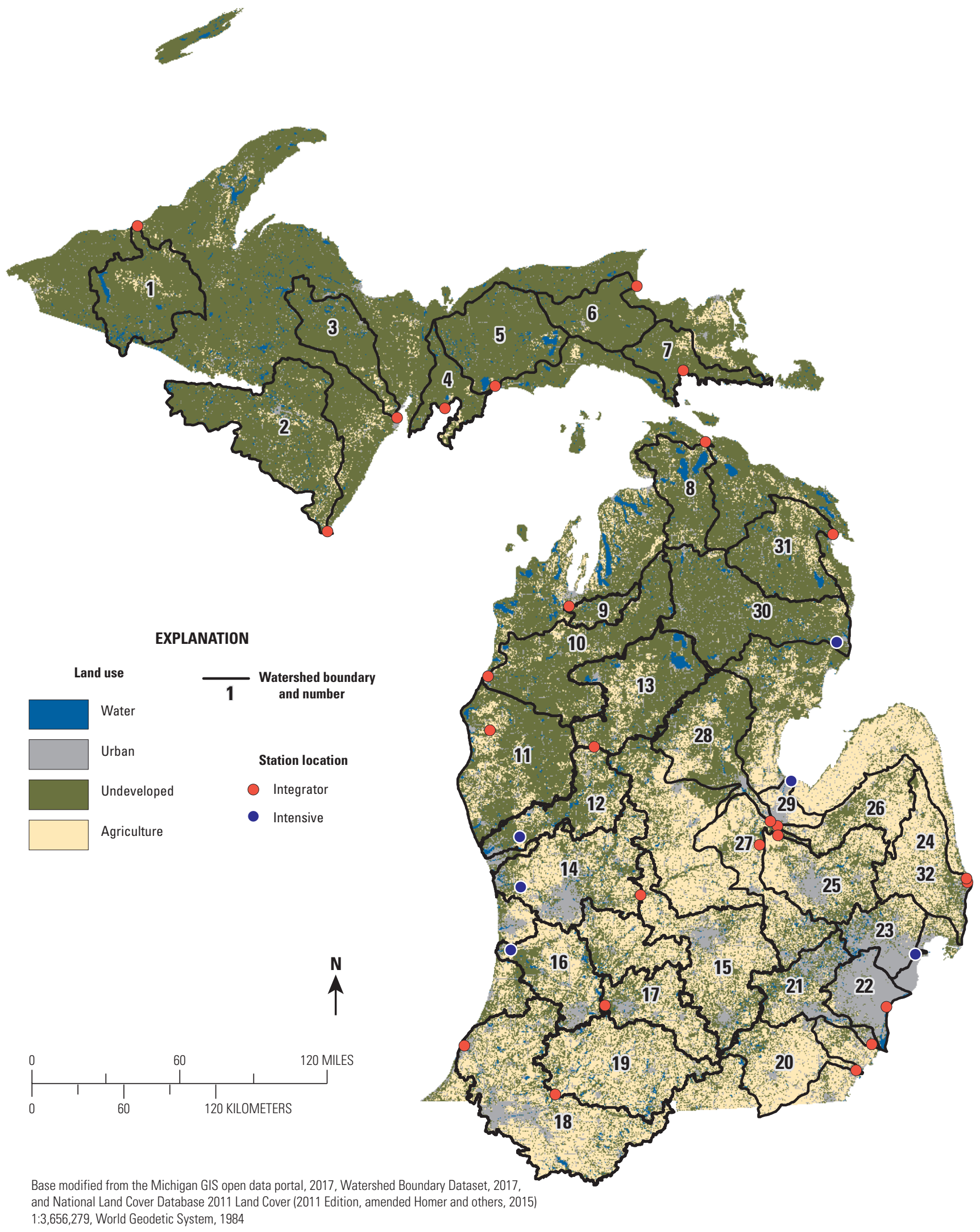

Figure 1. Michigan watersheds and associated land cover studied as part of the Michigan Water Chemistry Monitoring Program. 
major driving forces of the ecological transition of Lake Erie to this harmful eutrophic state (International Joint Commission, 2014). The overall mass of total phosphorus and nitrogen also has been implicated in causing large areas of hypoxia (dangerously low dissolved oxygen) in Lake Erie, which has ecological and economic consequences for the commercial fishery in Lake Erie's central basin (International Joint Commission, 2014).

By developing an understanding of the load of a constituent, in addition to evaluating the flow and seasonally normalized trends in a constituent, scientists are able to derive an understanding of which constituents might be driven more by point sources (those loads that are constant regardless of changes in streamflow) with those that might be more driven by nonpoint sources.

\section{Water Chemistry Monitoring Program}

In 1998, the MDEQ began monitoring 27 watersheds in Michigan as part of the WCMP (fig. 1). The program used the MDEQ watershed-management units and 5-year rotational cycle developed by the MDEQ Ambient Surface WCMP (Michigan Department of Environmental Quality, 2001) to assess Michigan streams and channels connecting the Great Lakes and bays. The objectives of the WCMP were to provide assistance with (1) statewide water-quality assessments, (2) the National Pollutant Discharge Elimination System permitting process, and (3) water-resource-management decisions.

The areas selected for monitoring coincide with USGS eight-digit hydrologic units throughout the State. Sampling locations in these hydrologic units were selected near the mouth of major streams that drain to the Great Lakes to determine the quality of the water directly entering the Great Lake into which each river drained. Land use in the watersheds differed from primarily undeveloped forest in the northern part of the State to more developed urban centers in the southern part of the State (fig. 1). Land-use categories differing from urban to undeveloped were represented by six hydrologic units that were monitored every year. Different land-use categories also were represented by 21 other hydrologic units that were monitored through 26 sampling stations (table 1).

\section{Previous Studies and Data}

Since 2001, several reports summarizing the WCMP data for the State of Michigan have been published by the MDEQ (Michigan Department of Environmental Quality, 2001, 2002, 2003, 2004, 2005, 2006a, 2008, 2013). Previously published WCMP reports summarizing annual and 5-year results are available from the MDEQ, Water Resources Division, Water Chemistry web page at http://www.michigan. gov/deq/0,4561,7-135-3313_3686_3728-32361—,00.html. The information provided includes constituent load estimates for total phosphorus, chloride, total suspended solids (TSS), mercury, chromium, copper, and lead for selected tributaries in the WCMP.

In 2009, the USGS published water-quality trend results for the selected streams in the WCMP for data collected during 1998-2005 (Hoard and others, 2009). The 2009 USGS report describes water-quality trends observed during the first 7 years of the WCMP. Results of the assessment of the first 7 years of data identified several constituents with values either decreasing or increasing during 1998-2005. Upward trends were identified at multiple rivers for chloride, nitrite, and copper concentrations. Downward trends for turbidity, ammonia, total phosphorus, total Kjeldahl nitrogen (TKN), chromium, and lead also were identified at multiple rivers.

In 2013, the MDEQ published a report (Michigan Department of Environmental Quality, 2013) that provided a summary of various aspects of the WCMP. Spatial variability of water-quality constituents was assessed for the State of Michigan using a probabilistic sampling approach. In addition, trends during 1998-2008 for select water-quality parameters were estimated for the same 31 stream stations analyzed in Hoard and others (2009) as well as for select Great Lakes connecting channels and large bays (Roush, 2013). With the addition of 3 years of data collection, trend estimates did differ between the two reports. For example, chloride was identified as having a statistically significant trend ( $p$-value 0.05 ) for nine locations in Roush (2013) as opposed to three locations in Hoard and others (2009).

\section{Purpose and Scope}

The purpose of this report is to summarize the estimated trends and loads for select water-quality constituents collected as part of the MDEQ WCMP from 1998 to 2013. Trends in water-quality constituents were estimated for 32 stream stations in 27 watersheds throughout Michigan using either the Seasonal Kendall test or Tobit regression trend estimation methods. Trends were estimated for select physical characteristics of water, nutrients, trace metals, and chloride. Annual constituent loads were estimated for the stream stations sampled 12 times per year using the Beale ratio estimator approach. Constituent loads were estimated for chloride, TSS, total phosphorus, mercury, lead, copper, and chromium for 30 stations from 27 watersheds using flow and concentration data collected from 2002 to 2013. All chemical and physical data, and sample-related metadata, at all stations presented in this report are available online in the USGS National Water Information System (NWIS) database. These data can be accessed using station information documented in this report at https:// nwis.waterdata.usgs.gov/mi/nwis/qwdata. Flow adjusted concentrations and annual constituent loads are reported in this document and are not stored in the NWIS database. 
Table 1. Stations sampled as part of the Michigan Water Chemistry Monitoring Program.

[Bold text indicates intensively sampled site; USGS, U.S. Geological Survey; EPA, U.S. Environmental Protection Agency; STORET, Storage and Retrieval System (water-quality data, EPA); Mich., Michigan]

\begin{tabular}{|c|c|c|c|c|c|}
\hline $\begin{array}{c}\text { Watershed } \\
\text { number }\end{array}$ & Station name & $\begin{array}{c}\text { USGS } \\
\text { station } \\
\text { number }\end{array}$ & $\begin{array}{c}\text { EPA } \\
\text { STORET } \\
\text { number }\end{array}$ & Latitude & Longitude \\
\hline 1 & Ontonagon River at Ontonagon, Mich. & 04040018 & 660038 & 46.8674 & -89.3171 \\
\hline 2 & Menominee River at Menominee, Mich. & 04067648 & 550038 & 45.1064 & -87.6357 \\
\hline 3 & Escanaba River at Wells, Mich. & 040590345 & 210102 & 45.7811 & -87.0675 \\
\hline 4 & Sturgeon River at County Road 499 at Nahma, Mich. & 04057521 & 210032 & 45.8408 & -86.6688 \\
\hline 5 & Manistique River Above Manistique, Mich. & 04057004 & 770073 & 45.9716 & -86.2432 \\
\hline 6 & Tahquamenon River at Emerson, Mich. & 04045510 & 170141 & 46.5564 & -85.0387 \\
\hline 7 & Pine River near Charles, Mich. & 04127925 & 490006 & 46.0570 & -84.6570 \\
\hline 8 & Cheboygan River at Cheboygan, Mich. & 04132052 & 160073 & 45.6339 & -84.4811 \\
\hline 9 & Boardman River near Traverse City, Mich. & 04127200 & 280014 & 44.6753 & -85.6309 \\
\hline 10 & Manistee River at Parkdale, Mich. & 04126010 & 510088 & 44.2642 & -86.2954 \\
\hline 11 & Pere Marquette River at Scottville, Mich. & 04122500 & 530027 & 43.9450 & -86.2787 \\
\hline 12 & Muskegon River near Bridgeton, Mich. (lower) & 04122030 & 610273 & 43.3181 & -86.0364 \\
\hline 13 & Muskegon River near Hersey, Mich. (upper) & 04121621 & 670008 & 43.8472 & -85.4322 \\
\hline 14 & Grand River near Eastmanville, Mich. (lower) & 04119400 & 700123 & 43.0242 & -86.0264 \\
\hline 15 & Grand River at Ionia, Mich. (upper) & 04116000 & 340025 & 42.9720 & -85.0692 \\
\hline 16 & Kalamazoo River at New Richmond, Mich. (lower) & 04108660 & 030077 & 42.6517 & -86.1078 \\
\hline 17 & Kalamazoo River near Augusta, Mich. (upper) & 04105707 & 390057 & 42.3256 & -85.3589 \\
\hline 18 & St. Joseph River at Napier Ave at St. Joseph, Mich. (lower) & 04102080 & 110628 & 42.0892 & -86.4747 \\
\hline 19 & St. Joseph River at Mottville, Mich. (upper) & 04099000 & 750273 & 41.8009 & -85.7561 \\
\hline 20 & River Raisin at Monroe, Mich. & 04176540 & 580046 & 41.9134 & -83.3847 \\
\hline 21 & Huron River at Rockwood, Mich. & 04175120 & 580364 & 42.0642 & -83.2539 \\
\hline 22 & River Rouge at River Rouge, Mich. & 04168550 & 820070 & 42.2806 & -83.1288 \\
\hline 23 & Clinton River at Gratiot Avenue at Mt. Clemens, Mich. & 04165553 & 500233 & 42.5839 & $-\mathbf{8 2 . 8 8 2 7}$ \\
\hline 24 & Black River at Port Huron, Mich. & 04160075 & 740385 & 42.9944 & -82.4450 \\
\hline 25 & Flint River near Fosters, Mich. & 04149000 & 730285 & 43.3084 & -83.9536 \\
\hline 26 & Cass River near Bridgeport, Mich. & 04152002 & 730024 & 43.3650 & -83.9550 \\
\hline 27 & Shiawassee River near Fergus, Mich. & 04145000 & 730023 & 43.2547 & -84.1055 \\
\hline 28 & Tittabawassee River at Center Road near Saginaw, Mich. & 04156510 & 730025 & 43.3936 & -84.0150 \\
\hline 29 & Saginaw River at Weadock Road at Essexville, Mich. & 04157065 & 090177 & 43.6281 & -83.8366 \\
\hline 30 & Au Sable River near Au Sable, Mich. & 04137500 & 350061 & 44.4364 & -83.4339 \\
\hline 31 & Thunder Bay at Alpena, Mich. & 04135020 & 040123 & 45.0708 & -83.4378 \\
\hline 32 & Black River near Port Huron, Mich. & 04160055 & 740267 & 43.0175 & -82.4530 \\
\hline
\end{tabular}




\section{Approach}

\section{Monitoring Program Design}

The sample design for the WCMP has been described in detail in previous reports (Roush, 2013; Hoard and others, 2009). However, the monitoring program and water-quality sample design for the sampling stations and data used for this report are described in this section. Selected sampling stations were designated as either intensive or integrator stations (fig. 1).

From 2001 to 2013, 6 intensive stations were sampled 12 times annually. These samples were not collected at even intervals during the year, instead eight samples were collected targeting high-flow events. Samples also were collected between 1998 and 2000; however, samples were not collected continuously during that period. Samples were collected during the part of the year when rivers were free of ice, which in most cases was March through November.

The other type of sampling station studied during this program was the integrator station (fig. 1). Integrator stations were sampled at varying frequency, but were typically sampled four times annually. During a typical year, an integrator station was sampled at approximately even intervals during the ice-free period of the year. Each integrator station also was sampled 12 times annually on a 5 -year rotating basis. The WCMP distribution of samples by year for intensive and integrator stations in Michigan is listed in table 2.

During the study period, the determination was made that the original station for monitoring the Black River watershed (Black River at Port Huron, Michigan; USGS station 04160075; watershed number 24) was likely representing a mix of Lake Huron and the Black River. This station was moved in 2006 to the Black River near Port Huron, Mich. (USGS station 04160055; watershed number 32), which is further upstream and is not affected by mixing from Lake Huron. Therefore, trends were estimated from 2000 to 2005 for the Black River at Port Huron, Mich. (USGS station 04160075) and from 2006 to 2013 for the Black River near Port Huron, Mich. (USGS station 04160055). Trend results for both stations are reported.

\section{Sample Collection}

For wadeable streams, water samples for trace metals and total mercury were collected as a single grab sample in the center of flow about 2-3 feet below the water surface. If a wading sample was not possible, water samples for mercury and trace metals were collected using a peristaltic pump either from a bridge or a boat with C-Flex tubing connected to 6-15 feet of Teflon tubing. The Teflon tubing was connected to a Teflon counter weight and dropped below the surface, about 2-3 feet, in the center of the channel. Water samples for mercury analysis were collected in 500 milliliter Teflon bottles, and water samples for analysis of trace metals were collected in 250 milliliter Teflon bottles. Before sampling, the tubing was rinsed with sample water for 5 minutes. Sample bottles were sealed in plastic bags and placed on ice in a cooler until final processing and transportation. The Teflon and C-Flex tubing were rinsed with 2-percent nitric acid and then rinsed in deionized water. The Teflon line was stored until the next sampling, whereas the C-Flex tubing was sent back to the Wisconsin State Lab of Hygiene. Water samples for mercury and trace metals were shipped in a cooler with ice to the Wisconsin State Lab of Hygiene, Madison, Wisconsin, within 48 hours of sample collection.

For wadeable streams and for streams where a wading sample was not possible, water samples for nutrients, chloride, and TSS were collected as a single grab sample in the center of flow about 2-3 feet below the water surface in 500 milliliter polypropylene bottles by using grab, peristaltic pump, sampling can, and Van Dorn samplers, as appropriate. Sample bottles were placed on ice in a cooler until final processing and transportation. The samples that were analyzed for total organic carbon, nitrate, nitrite, ammonia, TKN, and total phosphorus were amended with 10 drops of concentrated sulfuric acid in the field to preserve the samples. Peristaltic tubing used for sampling was then cleaned using phosphate free detergent, rinsed with deionized water, and then stored for the next sampling. Samples were placed in a cooler with ice and shipped or transported to the MDEQ Environmental Laboratory, Lansing, Mich., within 48 hours of sample collection. Results for all analyses are stored in the USGS NWIS database (https://waterdata.usgs.gov/nwis/nwis).

\section{Quality Assurance Samples}

As part of the WCMP, field blank and replicate samples were collected for the purpose of quality assurance. Field blank samples were used to assess whether or not the sampling equipment or methods were introducing contamination to the samples collected. Field blank samples were collected using blank water of known chemical quality during sample processing and submitting that sample for analysis. Between 6 and 15 blank samples were collected and analyzed annually for all the constituents. To put the blank sample analysis into context, knowledge of how to report lab results is required. For the nonmetal constituents, a minimum reporting level is the level at which a concentration can be quantified, so that above that level a value is reported and below that level the value is censored. For the trace metal constituents, two levels are used; a quantification level and a method detection level. The quantification level is the concentration at which a constituent can be quantified with certainty. The method detection level is defined as the smallest concentration that can be measured and reported with 99 percent confidence that the analyte concentration is greater than zero (Bonn, 2008). Any trace metal constituent with a result below the method detection level was reported as a censored value. 

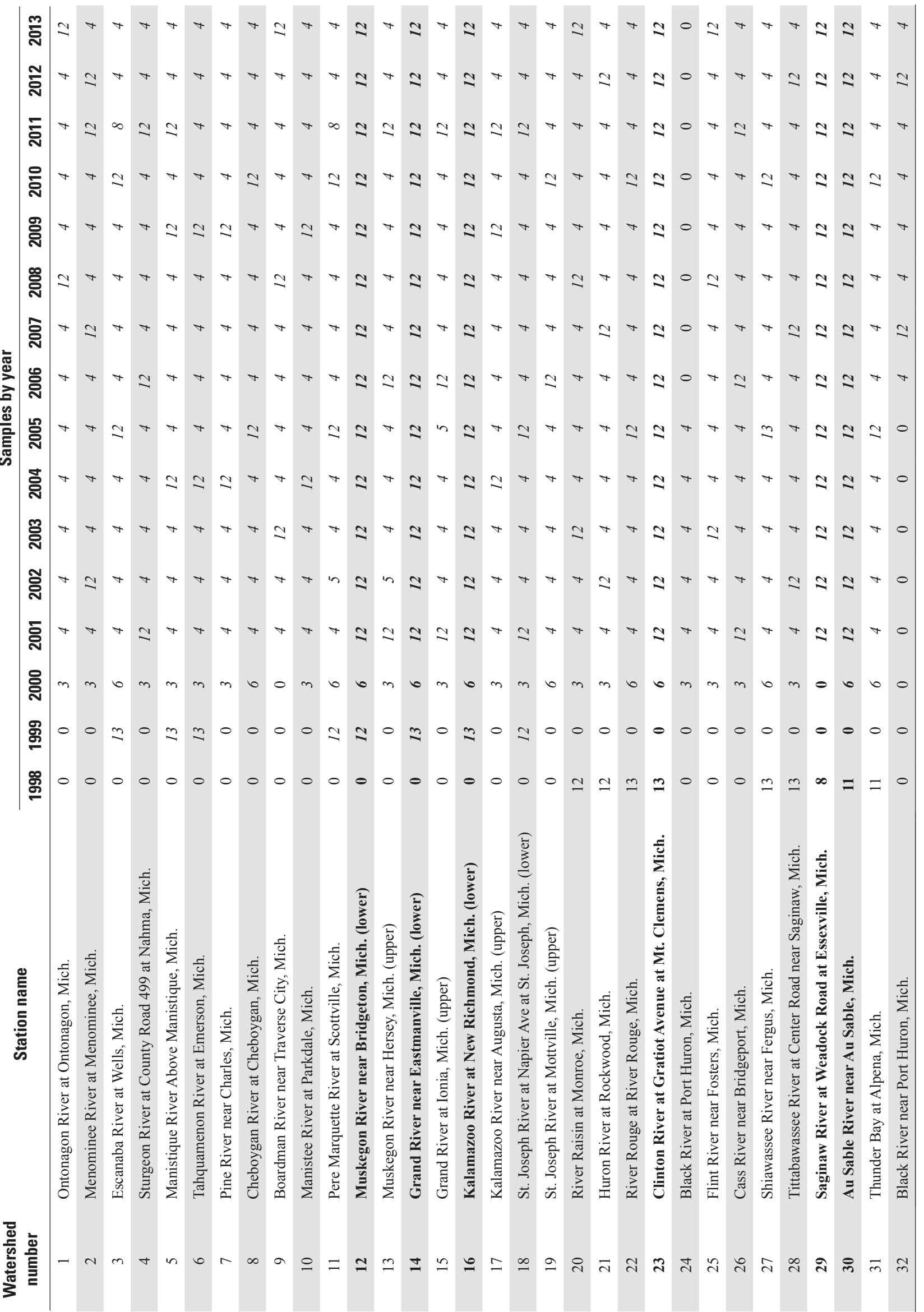
Concentrations that are estimated are values that have less certainty associated with their reported quantity. In the nonmetal constituents, estimated values were reported in cases when the lab had to adjust a procedure that may increase uncertainty in a result. For example, dilution may be required to analyze a sample or matrix interference may affect the analysis of the sample. In addition to the previous examples, the concentration of a trace metal constituent also can be qualified as estimated when a concentration is reported that is above the detection level but below the quantification level. The concentration is qualified as estimated because the reported concentration is less certain than a concentration above the quantification level.

In general, the blank sample results were below the minimum reporting level or quantification level for nonmetal and trace metal constituents, respectively. Constituents were only above the minimum reporting and quantification levels in about 4.5 percent of blank samples (table 3 ). Nutrient species were the most prevalent constituents with some quantifiable concentration in blank samples. Orthophosphate, nitrite, ammonia, and nitrate had estimated and detected levels in blanks at about $61,48,45$, and 15 percent, respectively (table 3). These results indicate the possibility of some lowlevel contamination in the nutrient species collected during this study.

Sequential replicate samples were used to assist in determining the variability in constituent concentrations as a result of sample collection, processing, and natural variability in the stream. The number of replicate samples collected ranged from 243 to 263, dependent on the constituent (table 4).
Comparison of the environmental samples to the replicate samples collected indicates that most constituents have a low relative percent difference in concentration between the original environmental sample and the replicate environmental sample (table 4). Median values of relative percent difference are low indicating good precision in analysis and generally low natural variability in the stream. However, although most constituents had low variability, the maximum relative percent difference could be high for certain constituents. The large value for maximum relative percent difference (table 4) indicates lower precision and higher environmental variability with the collection and analysis of mercury, copper, total phosphorus, and orthophosphate. For mercury, copper, total phosphorus, and orthophosphate the mean sample concentrations were generally near the minimum reporting level or quantification level. Consequently, small differences between the environmental and replicate samples can translate to a large percent difference among the sample results.

\section{Water-Quality Trend Analysis}

A trend is defined as a change in a single direction (upward/downward) in constituent concentrations expressed as percent change per year. The statistical methods for estimating trends in water quality were developed in ESTREND (Schertz and others, 1991) and converted to a library (S-ESTREND) for use in S-PLUS, a statistical software package. The library and documentation for S-PLUS can be obtained in Slack and others (2003).

Table 3. Summary of quality control field blank samples collected for the Water Chemistry Monitoring Program.

[mg/L, milligrams per liter; N, Nitrogen; $\mu \mathrm{g} / \mathrm{L}$, micrograms per liter; ng/L, nanograms per liter; $\mathrm{P}$, phosphorus]

\begin{tabular}{|c|c|c|c|c|}
\hline Constituent & $\begin{array}{c}\text { Number of } \\
\text { censored results }\end{array}$ & $\begin{array}{c}\text { Number of values } \\
\text { below quantification } \\
\text { but above the detection } \\
\text { level }\end{array}$ & $\begin{array}{c}\text { Number of samples } \\
\text { above quantification } \\
\text { level }\end{array}$ & Total samples \\
\hline Ammonia (mg/L as N) & 70 & 52 & 6 & 128 \\
\hline Chloride (mg/L) & 117 & 6 & 5 & 128 \\
\hline Chromium $(\mu \mathrm{g} / \mathrm{L})$ & 124 & 6 & 4 & 134 \\
\hline Lead $(\mu \mathrm{g} / \mathrm{L})$ & 123 & 8 & 3 & 134 \\
\hline Mercury (ng/L) & 128 & 4 & 3 & 135 \\
\hline Nitrate (mg/L as N) & 100 & 14 & 3 & 117 \\
\hline Nitrite (mg/L as N) & 67 & 43 & 18 & 128 \\
\hline Total suspended solids (mg/L) & 116 & 4 & 7 & 127 \\
\hline
\end{tabular}




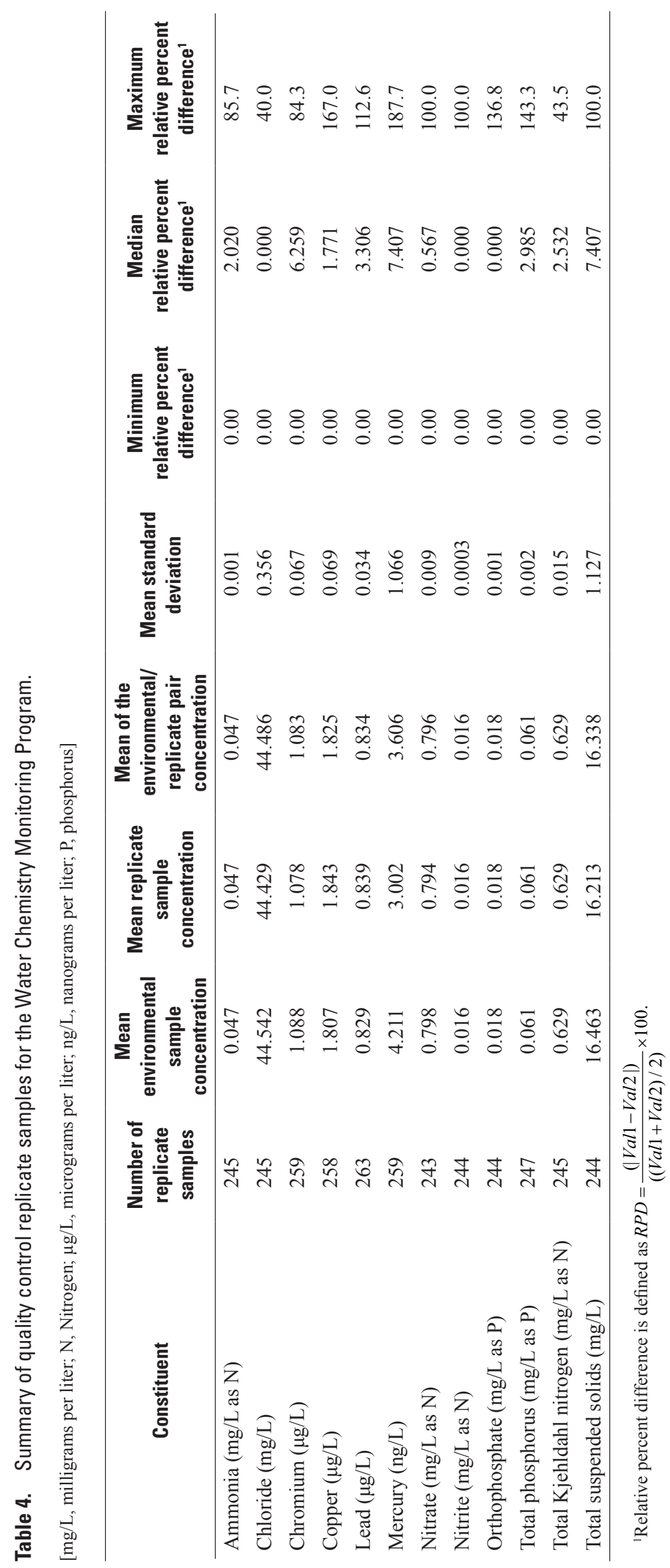


The nonparametric approach of the uncensored Seasonal Kendall test was chosen as the primary test for this study because of the characteristics of the water-quality data collected in the WCMP. The water-quality data collected as part of this program generally (1) were not normally distributed, (2) have seasonal variability in concentrations, (3) have variability in concentrations related to streamflow, (4) have some outlier concentration values, (5) have some censored concentration values, and (6) have some missing concentration values. The uncensored Seasonal Kendall test provides a means for analyzing data with those characteristics, whereas standard parametric procedures have difficulty evaluating this dataset (Hirsch and others, 1982; Hirsch and others, 1991).

The uncensored Seasonal Kendall test for trend detection has four principal data requirements. The period of record for a water-quality station must be at least 5 years (Schertz and others, 1991). The minimum number of samples that can be tested for a particular sampling station is at least 3 times the number of designated annual seasons, or at least a minimum of 10 samples (Schertz and others, 1991). Additionally, a minimum percentage, in this case 30 percent, of the total possible number of seasonal water-quality values in the beginning and ending fifths of the record must be present (Schertz and others, 1991). Finally, no more than 5 percent of the observed values can be censored (Schertz and others, 1991). Censored values are results for concentrations of constituents that are less than the laboratory method reporting level. These values are not quantified but are given a value of less than some reporting level.

Seasonal differences in concentrations of water-quality constituents can complicate the detection of trends. To detect a trend, the effect of seasonal differences on a constituent concentration needs to be removed. The ESTREND program removes the effect by dividing a year into seasons and only comparing sample data collected from similar seasons to estimate a trend (Schertz and others, 1991).

Seasons, for the different stations and constituents analyzed for trends, were defined on the basis of the sampling frequency at a station and the distribution of concentration data with time. The number of seasons per year used for this study was either 12, 6, 4, 3, or 2. The ESTREND program has an automated procedure for selecting the most appropriate number of seasons to use in the uncensored Seasonal Kendall test (Schertz and others, 1991). The program combines the beginning and ending fifths of the water-quality data for a constituent and compares that total to the middle three-fifths of the record. This procedure then calculates the total possible number of seasonal comparisons that could be made given a certain period of record and compares that total to the actual number of seasonal comparisons that can be made on the basis of the data available for a certain constituent at a station. The seasonal definition that had the largest number of seasons and that had 50 percent or more of the total possible seasonal matches was selected. Emphasis was placed on the beginning and ending fifths of the record, so the seasonal definition procedure weighted those portions of the record higher than the middle three-fifths of the record. When a season for a particular year had multiple samples, the most central value, with respect to time, that also was paired with a flow estimate was selected to represent the season (Schertz and others, 1991).

The concentrations of various water-quality constituents commonly are related to streamflow. As a result, the variance in the flow of a stream may be one of the major influences on a constituent concentration with time. In many cases, the influence of streamflow may be greater than the influence of other anthropogenic factors on constituent concentrations. In this case, any trend analysis test used essentially would be examining trends in streamflow as opposed to trends in constituent concentrations. To better understand the anthropogenic effect on the concentrations of water-quality constituents in streams, the effect that variation in streamflow has on constituent concentrations needs to be removed.

The ESTREND program provides a utility to remove the variability in constituent concentrations as a result of streamflow variability. This utility requires a streamflow estimate for each constituent concentration at each station being tested. The ESTREND program then computes a relation between the constituent concentration and the streamflow estimate, effectively creating a flow-adjusted concentration value (Schertz and others, 1991). For this study, a locally weighted scatter plot smoothing technique (Helsel and Hirsch, 2002) was used to develop the flow-adjusted concentration values. These flowadjusted concentration values were then tested for possible trends using the uncensored Seasonal Kendall test.

The parametric Tobit regression (Cohn, 1988; Schertz and others, 1991) also was used but only in cases where the data characteristics did not support using the uncensored Seasonal Kendall test. This trend estimation method was used for stations with constituents that had more than 5 percent but less than 50 percent censored values. When 50 percent or more values for a constituent at a station were censored, then no trend tests were attempted. Only seven constituents analyzed for trends were in that category - ammonia, chromium, nitrate, nitrite, orthophosphate, total phosphorus, and TSS. A description of the Tobit regression equation, data requirements, and how the equation accounts for variability in constituent concentration as a result of flow and season, are in Cohn (1988), Schertz and others (1991), and Slack and others (2003). When the Tobit regression method was used for trend estimation, a log transformation of the flow and constituent concentrations was implemented and seasonal terms were included to account for variability in constituent concentrations related to flow and seasonality.

A trend is considered to be statistically significant if the $p$-value of the trend test for a constituent is below a certain threshold. For this study, any trend with a $p$-value below 0.05 was considered statistically significant. The $p$-value is the probability that a detected trend resulted from a chance arrangement of the data, rather than from an actual change in constituent concentration. To illustrate, for a $p$-value of 0.05 a 5 -percent chance exists that a detected trend is an artifact of a chance arrangement of data as opposed to an actual trend in constituent concentrations. 


\section{Estimating Constituent Loads}

Water-quality data from the WCMP were used in conjunction with streamflow data to compute loads at select stations. Loads were computed using the Autobeale load computation program (Richards and others, 1996) in stratified mode so that loads computed from the WCMP data can be compared to loads computed the same way by the U.S. Environmental Protection Agency (Dolan and Chapra, 2012). Annual constituent loads were computed for chloride, TSS, total phosphorus, chromium, copper, lead, and mercury. Because of the rotational basis of sampling, loads were computed at the integrator stations on a rotational basis following the 5-year rotation of intensive sampling based on the MDEQ watershedmanagement unit rotation (fig. 1, table 5). Annual loads also were computed at the six intensive stations for every year that the WCMP trend program was active (fig. 1).

At the beginning of the WCMP, only 9 of 32 sampling locations selected for water-quality monitoring were either colocated or close enough to be considered flow equivalent with a USGS streamflow-gaging station. When a streamflowgaging station was not at the sampling station, a drainage-area multiplier (Archfield and Vogel, 2010) was determined for the area that contributed flow to that sample station. This multiplier was used in conjunction with the flow from a nearby streamflow-gaging station, usually upstream, to estimate the daily mean streamflow at the sample location. The Kalamazoo River near Augusta, Mich. (upper) (USGS station 04105707), Black River near Port Huron, Mich. (USGS station 04160055), and River Rouge (USGS station 04176540) were either the sum of multiple upstream gages or a combination of the sum of upstream gages and the use of a drainage area multiplier. Daily flows were provided by the dam operator for the Thunder Bay River at Alpena, Mich. (USGS station 04135020). Lastly, the Cheboygan River at Cheboygan, Mich. (USGS station 04132052) flow was estimated using a regression of flows from nearby gages. A compilation of the streamgages used to derive daily flow for each station that loads were estimated is listed in table 6.

\section{Water-Quality Trend Results}

Water-quality constituent results collected for the study are summarized in table 7 . The table provides a comparison of the range of values seen statewide and for the rivers sampled as part of the State of Michigan WCMP. Results of individual rivers sampled are available in appendixes 1 and 2 and can be used to identify how a specific river compares to the composite distribution of all water-quality results from the WCMP.

Water-quality data from 32 rivers sampled as part of the WCMP were analyzed for trends in ammonia, chloride, chromium, copper, lead, mercury, nitrate, nitrite, orthophosphate, total phosphorus, TKN, and TSS. Water-quality data were collected between 1998 and 2013; however, water-quality data were not collected continuously during that period. For instance, the Saginaw River at Essexville was sampled in 1998 and then not sampled again until 2001. The gap in that record caused problems with the trend estimation techniques used because too few records were at the beginning of the dataset. Therefore, only the periods with continuous data collection were used when estimating trends. For the Saginaw River, therefore, the trend estimate was for the period from 2001 to 2013. Similarly, trends in constituent concentrations were only estimated from 2000 onward for the Clinton, Au Sable, Raisin, Huron, Rouge, Shiawassee, Tittabawassee, and Thunder Bay Rivers and do not include data from the sampling seasons during 1998-99. The number of samples by year for each station and the period during which trends were estimated are listed in table 2. To provide a cross-reference with figures and tables, the watershed number for each river described in the results is included in parentheses following the river name.

\section{Trends in Chloride and Total Suspended Solids}

Trends in chloride flow-adjusted concentrations may be the result of natural or anthropogenic sources to the environment. Some examples of natural sources are saline groundwater or dissolution of evaporite deposits in the Michigan Basin (Westjohn and Weaver, 1998). Anthropogenic sources of chloride include road-deicing compounds, plant fertilizer, and wastewater effluent (Hem, 1985). An increase in chloride is generally considered a decrease in water quality. Few values were censored so the uncensored Seasonal Kendall trend test was used for all stations.

Of the 32 rivers analyzed for trends in chloride, five had statistically significant trends (table 8). One river had an estimated downward trend, whereas four rivers had estimated upward trends. The downward trend was in the Cass River (26). The decrease in chloride for that river was 1.07 percent per year. The four upward trends were in the Menominee (2), Manistique (5), lower St. Joseph (18), and Black Rivers (24). The increase in chloride for these rivers was 2.80, 1.40, 0.90, and 5.43 percent per year, respectively. The spatial distribution of chloride trends in Michigan is shown in figure 2. A pattern is not obvious in the spatial distribution of chloride trends throughout the State.

The concentration of the suspended material in a water sample are TSS. The TSS concentration is determined by filtering a water sample through a preweighed filter, then drying and weighing the filter to get the mass of material that was filtered. Large amounts of TSS in a water body can lead to increased water temperature, reduction of photosynthetic activity, and reduction in dissolved oxygen and, thus, degrading the water quality of the water body (Michigan Department of Environmental Quality, 2017). The TSS concentrations usually are correlated with streamflow, because high-flow events typically carry more suspended material than during low-flow events. Hence, flow-adjusted concentrations were used in the analyses. For TSS, two trend tests were used because of 


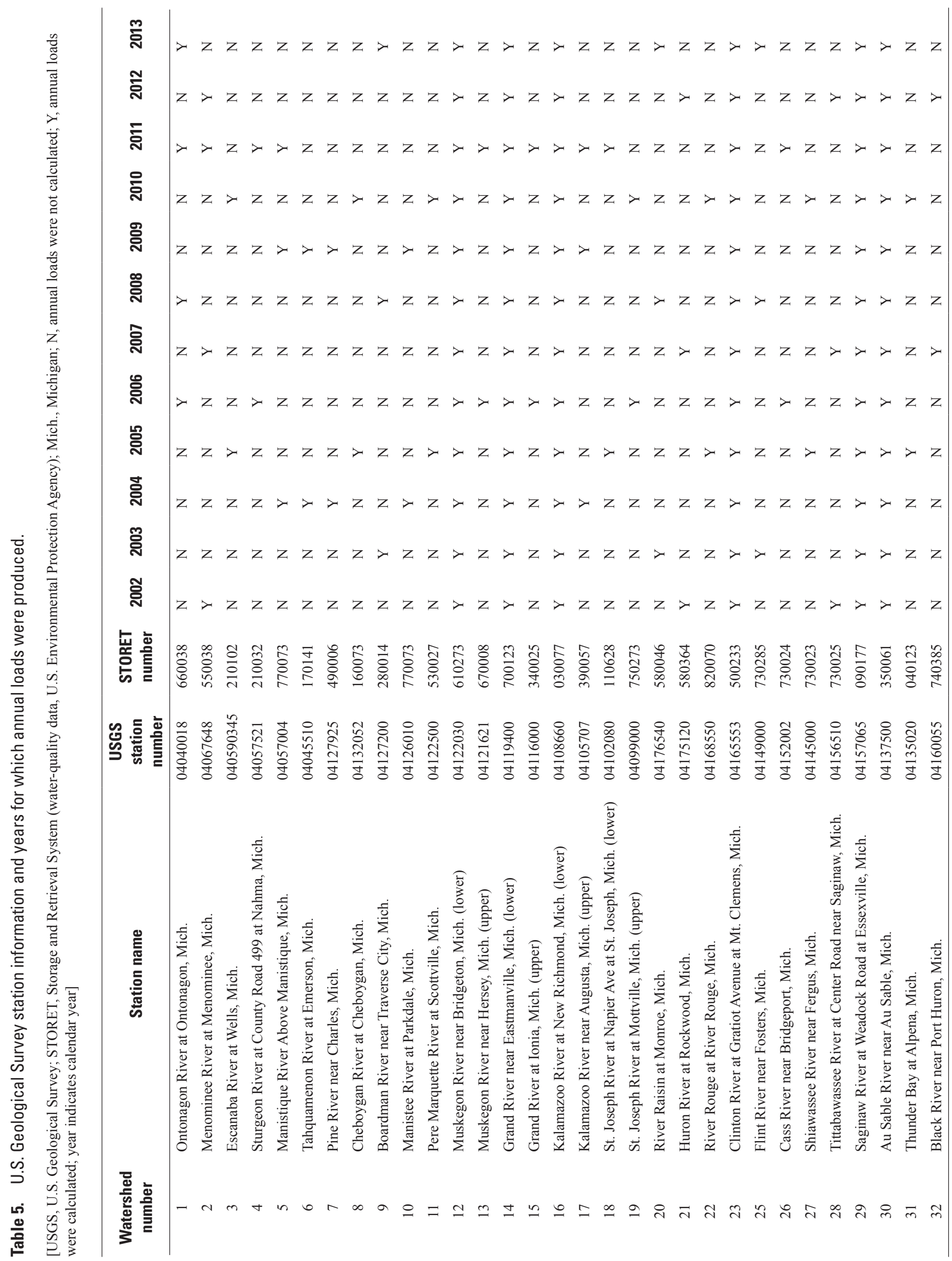




\section{Temporal Trends in Water-Quality Constituent Concentrations and Annual Loads of Chemical Constituents}

Table 6. U.S. Geological Survey stations used in the Water Chemistry Monitoring Program load computation.

[USGS, U.S. Geological Survey; Mich., Michigan]

\begin{tabular}{|c|c|c|c|c|}
\hline $\begin{array}{c}\text { Watershed } \\
\text { number }\end{array}$ & Station name & $\begin{array}{l}\text { USGS station } \\
\text { number } \\
\text { (sample } \\
\text { collection) }\end{array}$ & $\begin{array}{l}\text { USGS station number } \\
\text { (daily mean flow determination) }\end{array}$ & $\begin{array}{l}\text { Drainage } \\
\text { area } \\
\text { multiplier }\end{array}$ \\
\hline 1 & Ontonagon River at Ontonagon, Mich. & 04040018 & 04040000 & 1.03 \\
\hline 2 & Menominee River at Menominee, Mich. & 04067648 & 04067500 & 1.03 \\
\hline 3 & Escanaba River at Wells, Mich. & 040590345 & 04059000 & 1.00 \\
\hline 4 & Sturgeon River at County Road 499 at Nahma, Mich. & 04057521 & 04057510 & 1.20 \\
\hline 5 & Manistique River Above Manistique, Mich. & 04057004 & 04056500 & 1.34 \\
\hline 6 & Tahquamenon River at Emerson, Mich. & 04045510 & 04045500 & 1.07 \\
\hline 7 & Pine River near Charles, Mich. & 04127925 & 04127918 & 1.41 \\
\hline 8 & Cheboygan River at Cheboygan, Mich. & 04132052 & Special $^{1}$ & 1.00 \\
\hline 9 & Boardman River near Traverse City, Mich. & 04127200 & 04126970 & 1.91 \\
\hline 10 & Manistee River at Parkdale, Mich. & 04126010 & 04125550 & 1.25 \\
\hline 11 & Pere Marquette River at Scottville, Mich. & 04122500 & 04122500 & 1.00 \\
\hline 12 & Muskegon River near Bridgeton, Mich. (lower) & 04122030 & 04121970 & 1.07 \\
\hline 13 & Muskegon River near Hersey, Mich. (upper) & 04121621 & 04121500 & 1.15 \\
\hline 14 & Grand River near Eastmanville, Mich. (lower) & 04119400 & ${ }^{2} 04119000$ & ${ }^{2} 1.08$ \\
\hline 15 & Grand River at Ionia, Mich. (upper) & 04116000 & 04116000 & 1.00 \\
\hline 16 & Kalamazoo River at New Richmond, Mich. (lower) & 04108660 & 04108660 & 1.00 \\
\hline 17 & Kalamazoo River near Augusta, Mich. (upper) & 04105707 & Sum of 04105500 and 04105700 & 1.00 \\
\hline 18 & St. Joseph River at Napier Ave at St. Joseph, Mich. (lower) & 04102080 & 04101500 & 1.15 \\
\hline 19 & St. Joseph River at Mottville, Mich. (upper) & 04099000 & 04099000 & 1.00 \\
\hline 20 & River Raisin at Monroe, Mich. & 04176540 & 04176500 & 1.02 \\
\hline 21 & Huron River at Rockwood, Mich. & 04175120 & 04174500 & 1.17 \\
\hline 22 & River Rouge at River Rouge, Mich. & 04168550 & $\begin{array}{l}\text { Sum of } 04166500 \text { and } 04167000 \\
\text { and } 04168000\end{array}$ & 1.25 \\
\hline 23 & Clinton River at Gratiot Avenue at Mt. Clemens, Mich. & 04165553 & 04165500 & 1.00 \\
\hline 25 & Flint River near Fosters, Mich. & 04149000 & 04149000 & 1.00 \\
\hline 26 & Cass River near Bridgeport, Mich. & 04152002 & 04151500 & 1.08 \\
\hline 27 & Shiawassee River near Fergus, Mich. & 04145000 & 04145000 & 1.00 \\
\hline 28 & Tittabawassee River at Center Road near Saginaw, Mich. & 04156510 & 04156000 & 1.05 \\
\hline 29 & Saginaw River at Weadock Road at Essexville, Mich. & 04157065 & 04157000 & 1.04 \\
\hline 30 & Au Sable River near Au Sable, Mich. & 04137500 & 04137500 & 1.00 \\
\hline 31 & Thunder Bay at Alpena, Mich. & 04135020 & $\mathrm{Dam}^{3}$ & 1.00 \\
\hline 32 & Black River near Port Huron, Mich. & 04160055 & Sum of 04159492 and 04159900 & 1.08 \\
\hline
\end{tabular}

${ }^{1}$ Special, daily mean flow was computed via a weighted-linear regression analysis using the following formula (where the numbers represent the daily mean flow from the indicated USGS Station Numbers. Cheboygan daily mean flow $(04132052)=(1522.7 \times \ln (04127997+04130500+0412890))-8072.3$.

${ }^{2}$ Drainage area multiplier used from water years 2002-09, in water year 2010 a USGS streamgage was installed at the same location as sample collection and was used for load computation from water year 2010-13.

${ }^{3}$ Flow provided by dam operator. 
Table 7. Composite summary of constituent concentration data collected for the Water Chemistry Monitoring Program 1998-2013.

[mg/L, milligrams per liter; N, Nitrogen; <, less than; $\mu \mathrm{g} / \mathrm{L}$, micrograms per liter; ng/L, nanograms per liter; $\mathrm{P}$, phosphorus]

\begin{tabular}{lccccccc}
\hline \multicolumn{1}{c}{ Constituent } & $\begin{array}{c}\text { Number of } \\
\text { Samples }\end{array}$ & Minimum & $\begin{array}{c}\text { 25 percent } \\
\text { quantile }\end{array}$ & Mean & Median & $\begin{array}{c}\text { 75 percent } \\
\text { quantile }\end{array}$ & Maximum \\
\hline Ammonia $(\mathrm{mg} / \mathrm{L}$ as N) & 3,085 & $<0.01$ & 0.013 & 0.052 & 0.024 & 0.061 & 3.30 \\
Chloride $(\mathrm{mg} / \mathrm{L})$ & 3,086 & $<1$ & 8.00 & 41.639 & 28.0 & 58.0 & 447 \\
Chromium $(\mu \mathrm{g} / \mathrm{L})$ & 3,011 & $<0.002$ & 0.312 & 0.971 & 0.635 & 1.14 & 47.7 \\
Copper $(\mu \mathrm{g} / \mathrm{L})$ & 3,015 & $<0.001$ & 0.536 & 1.789 & 1.34 & 2.21 & 393.000 \\
Lead $(\mu \mathrm{g} / \mathrm{L})$ & 3,069 & 0.013 & 0.146 & 0.889 & 0.441 & 1.07 & 50.8 \\
Mercury $(\mathrm{ng} / \mathrm{L})$ & 3,056 & $<0.01$ & 1.14 & 3.323 & 2.09 & 4.04 & 304 \\
Nitrate $(\mathrm{mg} / \mathrm{L}$ as N) & 3,048 & 0.002 & 0.084 & 0.886 & 0.440 & 1.32 & 10.9 \\
Nitrite $(\mathrm{mg} / \mathrm{L}$ as N) & 3,083 & $<0.002$ & 0.005 & 0.016 & 0.010 & 0.022 & 0.250 \\
Orthophosphate $(\mathrm{mg} / \mathrm{L}$ as $\mathrm{P})$ & 2,989 & $<0.003$ & 0.005 & 0.022 & 0.010 & 0.026 & 4.00 \\
Total Kjehldahl nitrogen $(\mathrm{mg} / \mathrm{L}$ as N) & 3,087 & $<0.1$ & 0.400 & 0.665 & 0.630 & 0.880 & 4.70 \\
Total phosphorus $(\mathrm{mg} / \mathrm{L}$ as P) & 3,087 & $<0.005$ & 0.023 & 0.068 & 0.049 & 0.091 & 1.30 \\
Total suspended solids $(\mathrm{mg} / \mathrm{L})$ & 3,084 & $<4$ & 4.00 & 18.737 & 11.0 & 21.0 & 1,700 \\
\hline
\end{tabular}

the large number of censored values in the TSS dataset. The Seasonal Kendall trend test was used for the 14 rivers that had 5 percent or fewer censored values. Tobit regression was used on 13 rivers with greater than 5 percent censored values. The remaining five rivers either had more than 50 percent censored values or had a censored data distribution that confounded the trend estimation; therefore, trends for TSS for those stations were not tested. Nine rivers that were tested for trends had statistically significant trends, all of which were downward (table 7, fig. 2). The lower Muskegon (12), upper Muskegon (13), lower Grand (14), upper Grand (15), lower St. Joseph (18), Clinton (23), Cass (26), Tittabawassee (28), and Saginaw (29) Rivers indicated downward trends for TSS. The percent decrease per year was 3.89, 4.08, 3.78, 6.72, 6.70, 5.69, 5.79, 4.56 , and 4.66, respectively (appendix 1). These results indicate a general improvement in water quality with respect to suspended solids in the State of Michigan. Detected trends in TSS were all in the Lower Peninsula (fig. 2), primarily within the central and southern portion of Michigan.

\section{Trends in Nutrient Constituents}

The nutrient constituents analyzed as part of this study were flow-adjusted concentrations of ammonia, nitrate, nitrite, orthophosphate, total phosphorus, and TKN. Sources of nutrient constituents include, but are not limited to, fertilizers, wastewater effluent, and by-products of combustion of fossil fuels. A direct relation exists between nutrient concentration and algal growth, which can lead to eutrophication of water bodies. In other words, as the concentration of nutrient species increase, algae growth is stimulated and eutrophication of a water body may result (U.S. Environmental Protection Agency, 2017).
Trends in orthophosphate were problematic to assess at many rivers because of the low concentrations detected in samples. Only 19 rivers could be tested because of limitations associated with the number of censored values and the distribution of the data with time. Fourteen of the rivers required the Tobit regression technique to detect a trend, whereas the remaining 5 rivers (table 9) were analyzed using the Seasonal Kendall trend test. Five rivers had estimated trends in orthophosphate concentrations, three were upward trends and two were downward trends. The three upward trends were estimated in the Ontonagon (1) and lower Grand (14) Rivers, as well as in the Black River (32) near Port Huron, at rates of $9.19,3.15$, and 21.10 percent per year, respectively (appendix 1). Downward trends were estimated in the Escanaba (3) and upper Kalamazoo (17) Rivers at rates of 6.48 and 3.42 percent per year, respectively (appendix 1). The spatial distribution of orthophosphate trends in Michigan is shown in figure 2. Two trends are in the Upper Peninsula, and three trends are in the central and southern Lower Peninsula of the State.

Trends in total phosphorus concentration were detected in 6 of the 32 rivers that were analyzed (table 9). All trends detected were downward, likely indicating improvement in water quality with respect to total phosphorus. Three rivers required the Tobit regression technique because more than 5 percent of the concentrations were censored. The remaining 29 rivers were analyzed using the Seasonal Kendall trend test. Downward trends were estimated in the Pine (7), lower St. Joseph (18), Raisin (20), Clinton (23), Flint (25), and Cass (26) Rivers at percentages of 3.38, 4.24, 3.08, 3.37, 3.83, and 4.12, respectively (appendix 1). Spatially, the trends in total phosphorus are shown in figure 2. The trends are in the southern Lower Peninsula with the exception of the Pine (7) watersheds. 
Table 8. Trend results for chloride and total suspended solids at Michigan stream stations, 1999-2013.

[Mich., Michigan; -- , no trend detected; U, upward trend with $p$-value less than or equal to 0.05 ; NA, trend not tested because of data limitationd; D, downward trend with $p$-value less than or equal to 0.05 ]

\begin{tabular}{|c|c|c|c|}
\hline $\begin{array}{c}\text { Watershed } \\
\text { number }\end{array}$ & Station name & Chloride & $\begin{array}{c}\text { Total suspended } \\
\text { solids }\end{array}$ \\
\hline 1 & Ontonagon River at Ontonagon, Mich. & -- & -- \\
\hline 2 & Menominee River at Menominee, Mich. & $\mathrm{U}$ & NA \\
\hline 3 & Escanaba River at Wells, Mich. & -- & -- \\
\hline 4 & Sturgeon River at County Road 499 at Nahma, Mich. & -- & -- \\
\hline 5 & Manistique River Above Manistique, Mich. & $\mathrm{U}$ & -- \\
\hline 6 & Tahquamenon River at Emerson, Mich. & -- & NA \\
\hline 7 & Pine River near Charles, Mich. & -- & -- \\
\hline 8 & Cheboygan River at Cheboygan, Mich. & -- & NA \\
\hline 9 & Boardman River near Traverse City, Mich. & -- & -- \\
\hline 10 & Manistee River at Parkdale, Mich. & -- & -- \\
\hline 11 & Pere Marquette River at Scottville, Mich. & -- & -- \\
\hline 12 & Muskegon River near Bridgeton, Mich. (lower) & -- & $\mathrm{D}$ \\
\hline 13 & Muskegon River near Hersey, Mich. (upper) & -- & $\mathrm{D}$ \\
\hline 14 & Grand River near Eastmanville, Mich. (lower) & -- & $\mathrm{D}$ \\
\hline 15 & Grand River at Ionia, Mich. (upper) & -- & $\mathrm{D}$ \\
\hline 16 & Kalamazoo River at New Richmond, Mich. (lower) & -- & -- \\
\hline 17 & Kalamazoo River near Augusta, Mich. (upper) & -- & -- \\
\hline 18 & St. Joseph River at Napier Ave at St. Joseph, Mich. (lower) & $\mathrm{U}$ & $\mathrm{D}$ \\
\hline 19 & St. Joseph River at Mottville, Mich. (upper) & -- & -- \\
\hline 20 & River Raisin at Monroe, Mich. & -- & -- \\
\hline 21 & Huron River at Rockwood, Mich. & -- & -- \\
\hline 22 & River Rouge at River Rouge, Mich. & -- & -- \\
\hline 23 & Clinton River at Gratiot Avenue at Mt. Clemens, Mich. & -- & $\mathrm{D}$ \\
\hline 24 & Black River at Port Huron, Mich. & $\mathrm{U}$ & -- \\
\hline 25 & Flint River near Fosters, Mich. & -- & -- \\
\hline 26 & Cass River near Bridgeport, Mich. & $\mathrm{D}$ & $\mathrm{D}$ \\
\hline 27 & Shiawassee River near Fergus, Mich. & -- & -- \\
\hline 28 & Tittabawassee River at Center Road near Saginaw, Mich. & -- & $\mathrm{D}$ \\
\hline 29 & Saginaw River at Weadock Road at Essexville, Mich. & -- & $\mathrm{D}$ \\
\hline 30 & Au Sable River near Au Sable, Mich. & -- & NA \\
\hline 31 & Thunder Bay at Alpena, Mich. & -- & NA \\
\hline 32 & Black River near Port Huron, Mich. & -- & -- \\
\hline
\end{tabular}



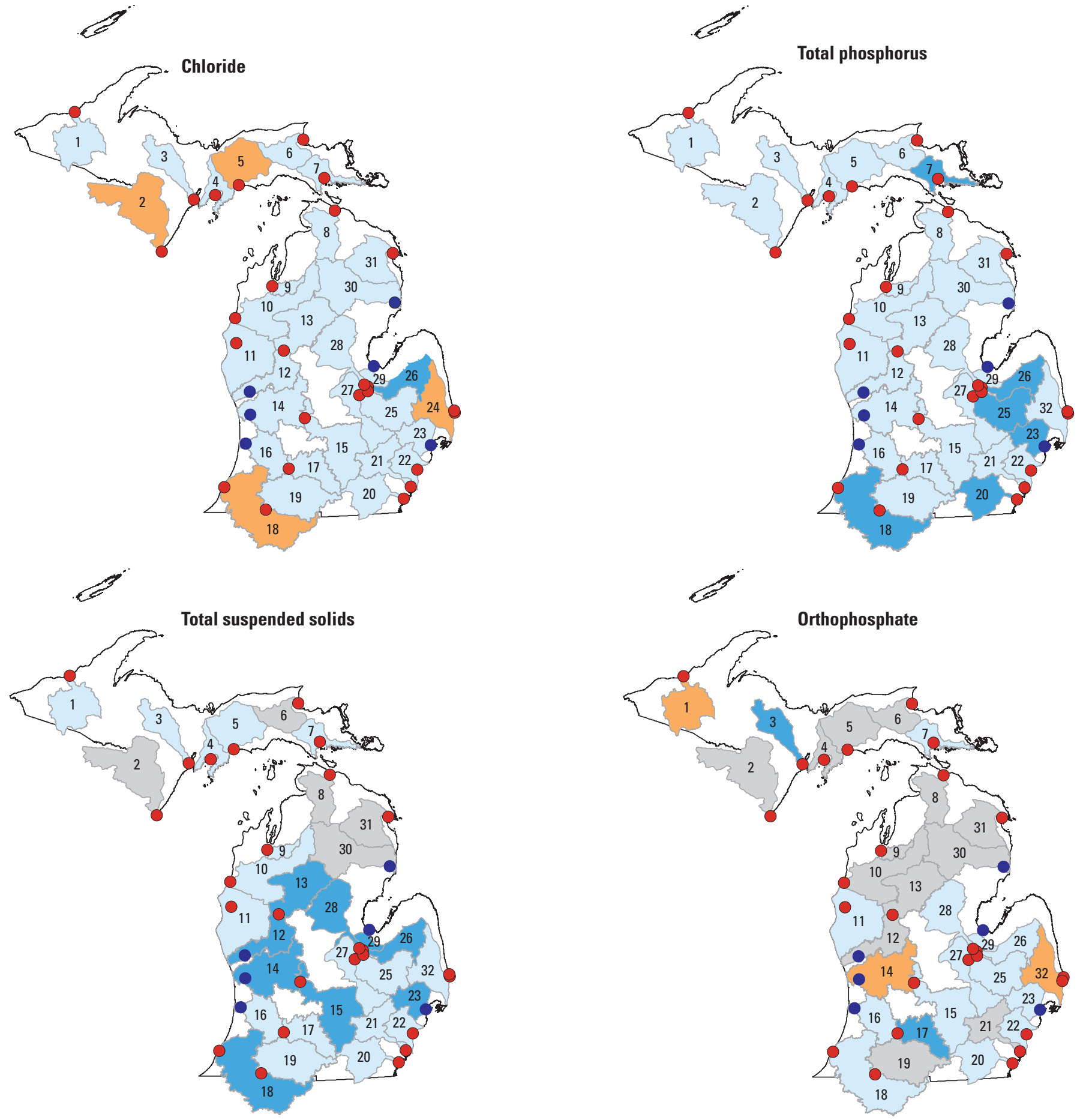

Base modified from the Michigan GIS open data portal, 2017 and the Watershed Boundary Dataset, 2017, 1:8,433,662

EXPLANATION World Geodetic System, 1984
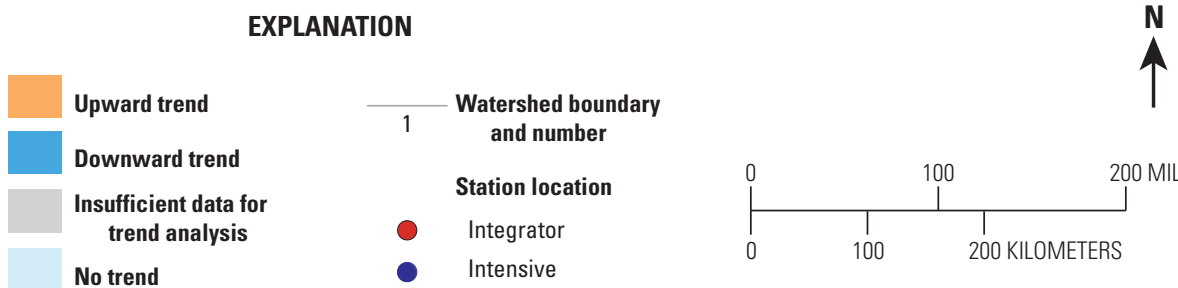

Figure 2. Trend results for chloride, total suspended solids, total phosphorus, and orthophosphate by Michigan watershed. 


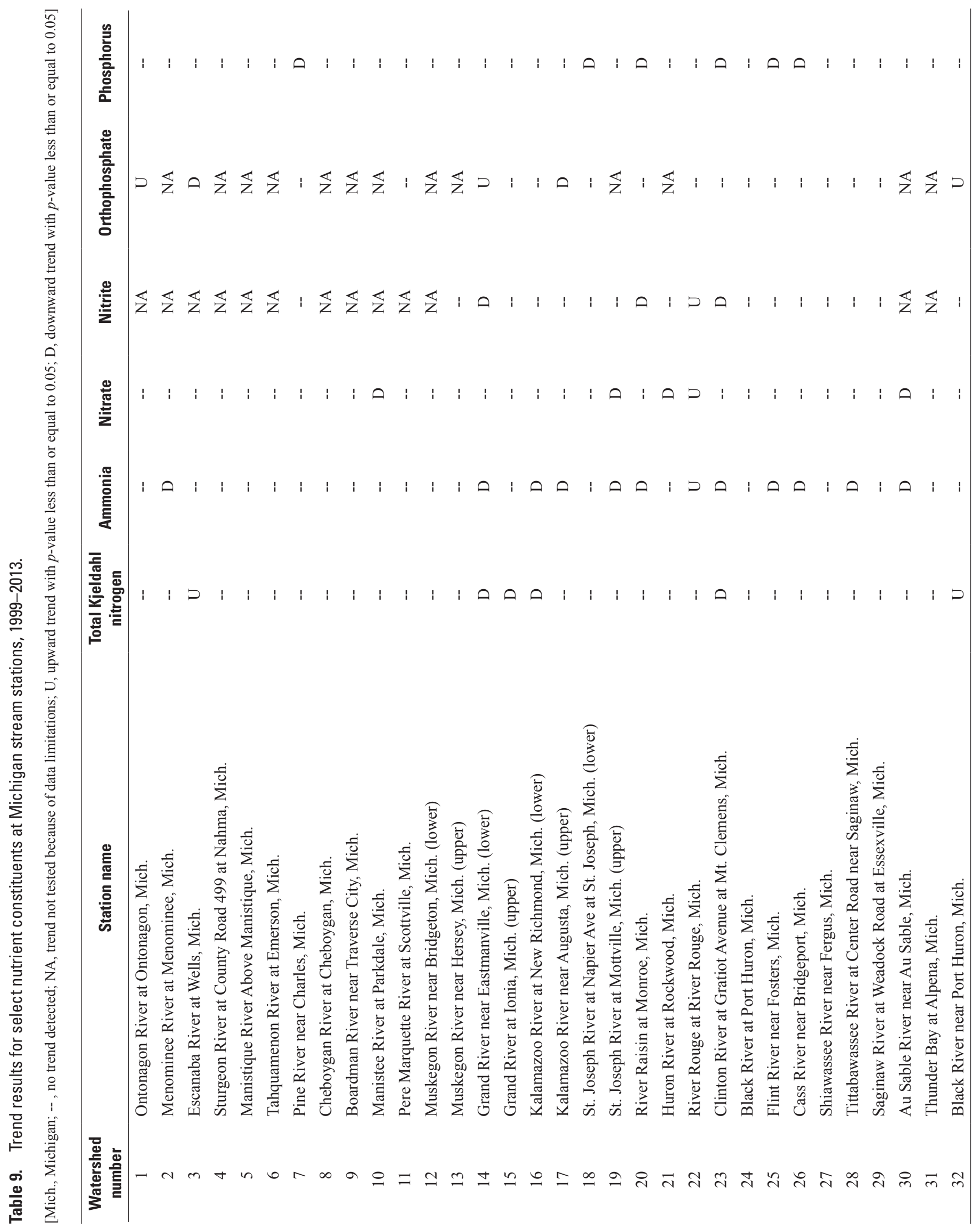


Trends in ammonia were detected more frequently than any other nutrient constituent. Trends were estimated at 12 of the 32 rivers analyzed. Two rivers had more than 5 percent of the ammonia results reported as censored values. Therefore, the Tobit regression technique was used for those two rivers, and the seasonal Kendall trend test was used for the remainder of the rivers (table 9). Of the 12 rivers with observed trends, 11 of the trends were downward and 1 trend was upward. The spatial distribution of ammonia trends in Michigan is shown in figure 3. The large number of rivers with downward trends throughout the State indicates an overall improvement in water quality with respect to ammonia. Only one river that was monitored indicated upward trends in ammonia, the River Rouge (22), with trends increasing at 5.39 percent per year (appendix 1).

Nitrate trends were detected in 5 of 32 rivers and all but 1 of those trends was downward, much like the ammonia results (table 9). Seven rivers had more than 5 percent of the nitrate results reported as censored values. For those seven rivers, the Tobit regression technique was used to estimate trends, and the remaining rivers were analyzed using the Seasonal Kendall trend test. The spatial distribution of nitrate trends in Michigan is shown in figure 3 . The distribution is similar to that of ammonia, but with fewer trends on the eastern one-half of the State. The Manistee (10), upper St. Joseph (19), Huron (21), and Au Sable (30) Rivers had significant downward trends at rates of $2.17,1.53,7.49$, and 3.65 percent per year, respectively (appendix 1). The River Rouge (22) was the only station with an upward trend in nitrate at 3.83 percent per year (appendix 1).

Trends in nitrite were problematic to assess mostly because concentrations were low and were censored more frequently than other constituents. Trends only could be analyzed for 19 of the 32 rivers because of limitations associated with the number of censored values and the distribution of the data with time. Of the 19 rivers that could be tested, 11 rivers required Tobit regression because more than 5 percent of the constituent concentrations were below the censoring level. The remaining eight rivers were tested by using the Seasonal Kendall trend test. Downward trends were estimated in three rivers (table 9) - the lower Grand (14), Clinton (23), and Raisin (20) Rivers, which declined at 2.66, 4.83, and 3.91 percent per year, respectively (appendix 1). An upward trend was estimated in the River Rouge (22), which increased at 5.97 percent per year (appendix 1). The spatial distribution of nitrite trends in Michigan is shown in figure 3.

The TKN is the concentration of the sum of organic nitrogen, ammonia, and the ammonium ion in solution. All 32 rivers were analyzed using the Seasonal Kendall trend test. Downward trends were estimated in four rivers and upward trends were estimated in two rivers (table 9). The rivers with downward trends were the lower Grand (14), upper Grand (15), lower Kalamazoo (16), and Clinton (23) Rivers at rates of $2.46,2.24,1.6$, and 1.57 percent per year, respectively (appendix 1). The two upward trends were detected in the Escanaba River (3) and the Black River (32) near Port Huron at rates of 2.66 and 5.30 percent per year, respectively (appendix 1). The spatial distribution of TKN trends in Michigan is shown in figure 3 . Trends are primarily in the southern and central Lower Peninsula with one increasing trend in the Upper Peninsula of the State.

\section{Trends in Trace Metals Concentrations}

The watersheds monitored as part of this study were analyzed to detect trends in trace metal flow-adjusted concentrations, including chromium, copper, lead, and mercury. Trace metals are released to the environment from natural sources as well as from anthropogenic processes. Some anthropogenic sources of trace metals include industrial processing, wastewater effluent, and atmospheric deposition of materials released into the atmosphere through industrial processes. In addition to various industrial uses of lead, from the 1920s through the 1980 s tetraethyl lead was added to "leaded" gasoline to increase power output from gasoline engines; therefore, lead is broadly distributed in the environment. At certain levels, trace metal constituents are toxic to humans (U.S. Environmental Protection Agency, 2016) as well as to aquatic organisms (Michigan Department of Environmental Quality, 2006b, 2016).

Trends in chromium were estimated in 9 of 32 rivers and all of the trends were upward (table 10). The Seasonal Kendall test was used for four of the rivers analyzed. The remaining six rivers required the Tobit regression technique because greater than 5 percent of the chromium values were censored (appendix 1). Those rivers that had significant upward trends were the Menominee (2), Sturgeon (4), Manistique (5), Cheboygan (8), Boardman (9), lower Muskegon (12), upper St. Joseph (19), Au Sable (30), and Thunder Bay (31) Rivers at rates of $4.65,7.16,4.18,16.8,23.2,5.65,12.7,26.7$, and 18.8 percent per year, respectively (appendix 1). The spatial distribution of chromium trends in Michigan is shown in figure 4. The trends shown are primarily in the Upper Peninsula and northern Lower Peninsula of the State. The prevalent upward trend generally indicates a decline in water quality. However, although the prevalence of upward trends may be a concern, the maximum concentrations measured at these rivers are still low (1.09-7.14 micrograms per liter) (appendix 1). The Michigan Rule 57 water-quality criteria final chronic value for aquatic environments with respect to chromium is dependent on the hardness of the water for a particular sample (Michigan Department of Environmental Quality, 2006b, 2016). Therefore, a specific number cannot be defined, rather a number that changes as the waters hardness changes. The maximum concentrations of the rivers with upward trends are still below the final chronic value for chromium of 109 and 92 micrograms per liter, respectively (appendix 1).

Trends in copper were detected in 4 of 32 rivers analyzed (table 10). All rivers were analyzed using the Seasonal Kendall analysis and four downward trends were estimated. The four downward trends for copper were at the Escanaba (3), lower 

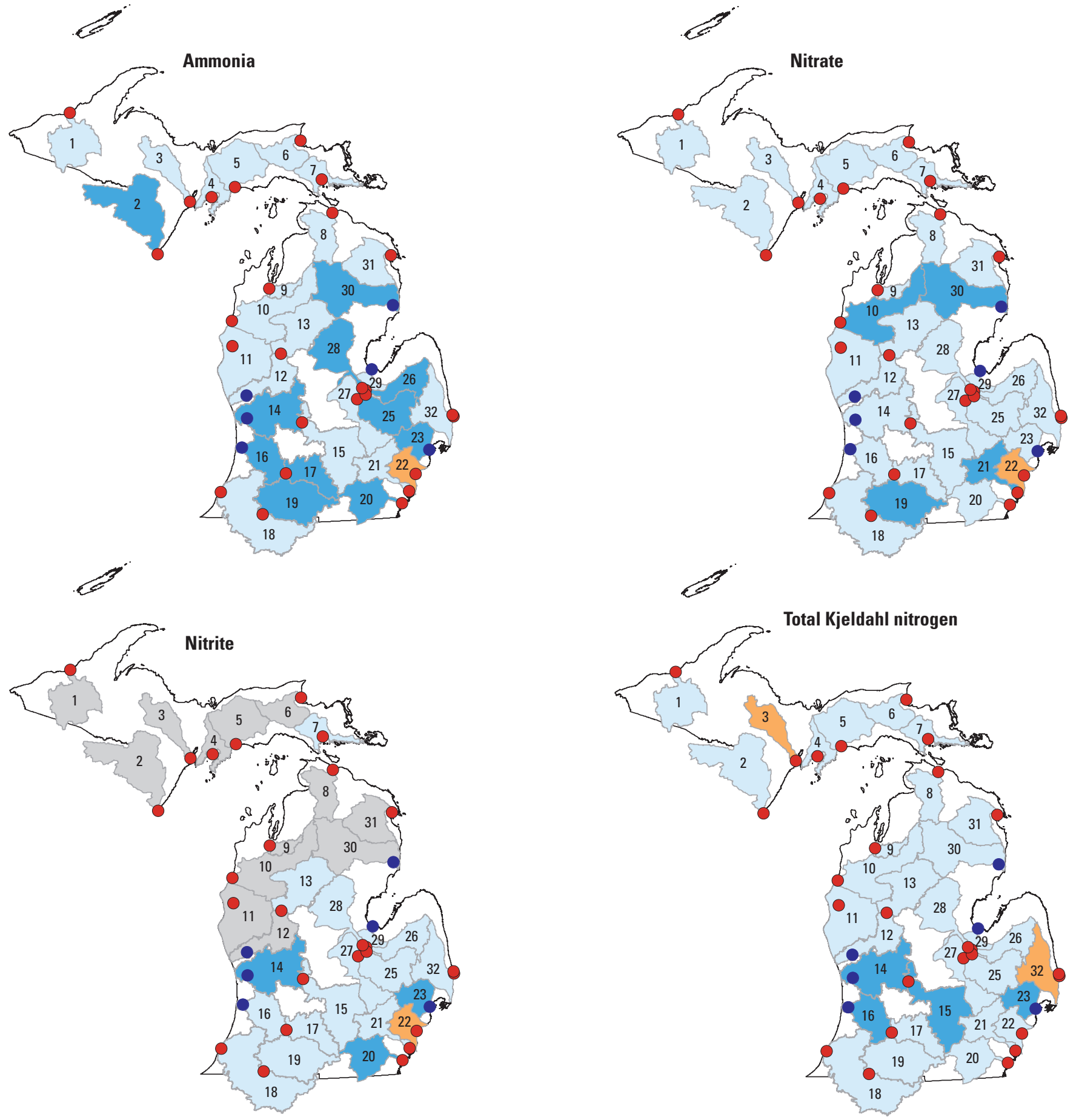

Base modified from the Michigan GIS open data portal, 2017 and the Watershed Boundary Dataset, 2017, 1:8,433,662

EXPLANATION World Geodetic System, 1984
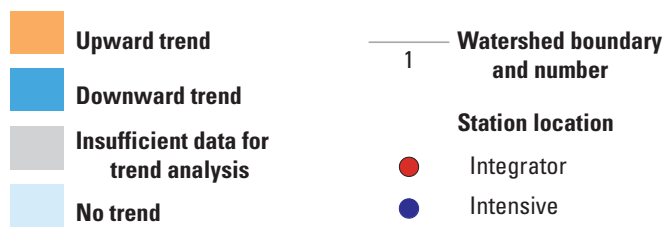

$\mathbf{N}$

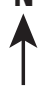

\section{.}


Table 10. Trend results for trace metal constituents at Michigan stream stations, 1999-2013.

[Mich.,Michigan; --, no trend detected; $\mathrm{U}$, upward trend with $p$-value less than or equal to 0.05 ; $\mathrm{D}$, downward trend with $p$-value less than or equal to 0.05$]$

\begin{tabular}{|c|c|c|c|c|c|}
\hline $\begin{array}{c}\text { Watershed } \\
\text { number }\end{array}$ & Station name & Chromium & Copper & Lead & Mercury \\
\hline 1 & Ontonagon River at Ontonagon, Mich. & -- & -- & $\mathrm{U}$ & -- \\
\hline 2 & Menominee River at Menominee, Mich. & $\mathrm{U}$ & -- & $\mathrm{D}$ & -- \\
\hline 3 & Escanaba River at Wells, Mich. & -- & $\mathrm{D}$ & -- & -- \\
\hline 4 & Sturgeon River at County Road 499 at Nahma, Mich. & $\mathrm{U}$ & -- & -- & $\mathrm{U}$ \\
\hline 5 & Manistique River Above Manistique, Mich. & $\mathrm{U}$ & -- & -- & -- \\
\hline 6 & Tahquamenon River at Emerson, Mich. & -- & -- & -- & -- \\
\hline 7 & Pine River near Charles, Mich. & -- & -- & -- & $\mathrm{U}$ \\
\hline 8 & Cheboygan River at Cheboygan, Mich. & $\mathrm{U}$ & -- & -- & $\mathrm{U}$ \\
\hline 9 & Boardman River near Traverse City, Mich. & $\mathrm{U}$ & -- & -- & -- \\
\hline 10 & Manistee River at Parkdale, Mich. & -- & -- & -- & -- \\
\hline 11 & Pere Marquette River at Scottville, Mich. & -- & -- & -- & -- \\
\hline 12 & Muskegon River near Bridgeton, Mich. (lower) & $\mathrm{U}$ & -- & -- & -- \\
\hline 13 & Muskegon River near Hersey, Mich. (upper) & -- & -- & -- & -- \\
\hline 14 & Grand River near Eastmanville, Mich. (lower) & -- & -- & $\mathrm{D}$ & -- \\
\hline 15 & Grand River at Ionia, Mich. (upper) & -- & -- & -- & -- \\
\hline 16 & Kalamazoo River at New Richmond, Mich. (lower) & -- & $\mathrm{D}$ & $\mathrm{D}$ & -- \\
\hline 17 & Kalamazoo River near Augusta, Mich. (upper) & -- & -- & -- & -- \\
\hline 18 & St. Joseph River at Napier Ave at St. Joseph, Mich. (lower) & -- & -- & $\mathrm{D}$ & -- \\
\hline 19 & St. Joseph River at Mottville, Mich. (upper) & $\mathrm{U}$ & -- & -- & -- \\
\hline 20 & River Raisin at Monroe, Mich. & -- & $\mathrm{D}$ & -- & -- \\
\hline 21 & Huron River at Rockwood, Mich. & -- & -- & -- & -- \\
\hline 22 & River Rouge at River Rouge, Mich. & -- & -- & -- & -- \\
\hline 23 & Clinton River at Gratiot Avenue at Mt. Clemens, Mich. & -- & $\mathrm{D}$ & $\mathrm{D}$ & -- \\
\hline 24 & Black River at Port Huron, Mich. & -- & -- & -- & -- \\
\hline 25 & Flint River near Fosters, Mich. & -- & -- & $\mathrm{D}$ & -- \\
\hline 26 & Cass River near Bridgeport, Mich. & -- & -- & $\mathrm{D}$ & -- \\
\hline 27 & Shiawassee River near Fergus, Mich. & -- & -- & -- & -- \\
\hline 28 & Tittabawassee River at Center Road near Saginaw, Mich. & -- & -- & $\mathrm{D}$ & -- \\
\hline 29 & Saginaw River at Weadock Road at Essexville, Mich. & -- & -- & $\mathrm{D}$ & -- \\
\hline 30 & Au Sable River near Au Sable, Mich. & $\mathrm{U}$ & -- & -- & $\mathrm{U}$ \\
\hline 31 & Thunder Bay at Alpena, Mich. & $\mathrm{U}$ & -- & -- & -- \\
\hline 32 & Black River near Port Huron, Mich. & -- & -- & -- & -- \\
\hline
\end{tabular}




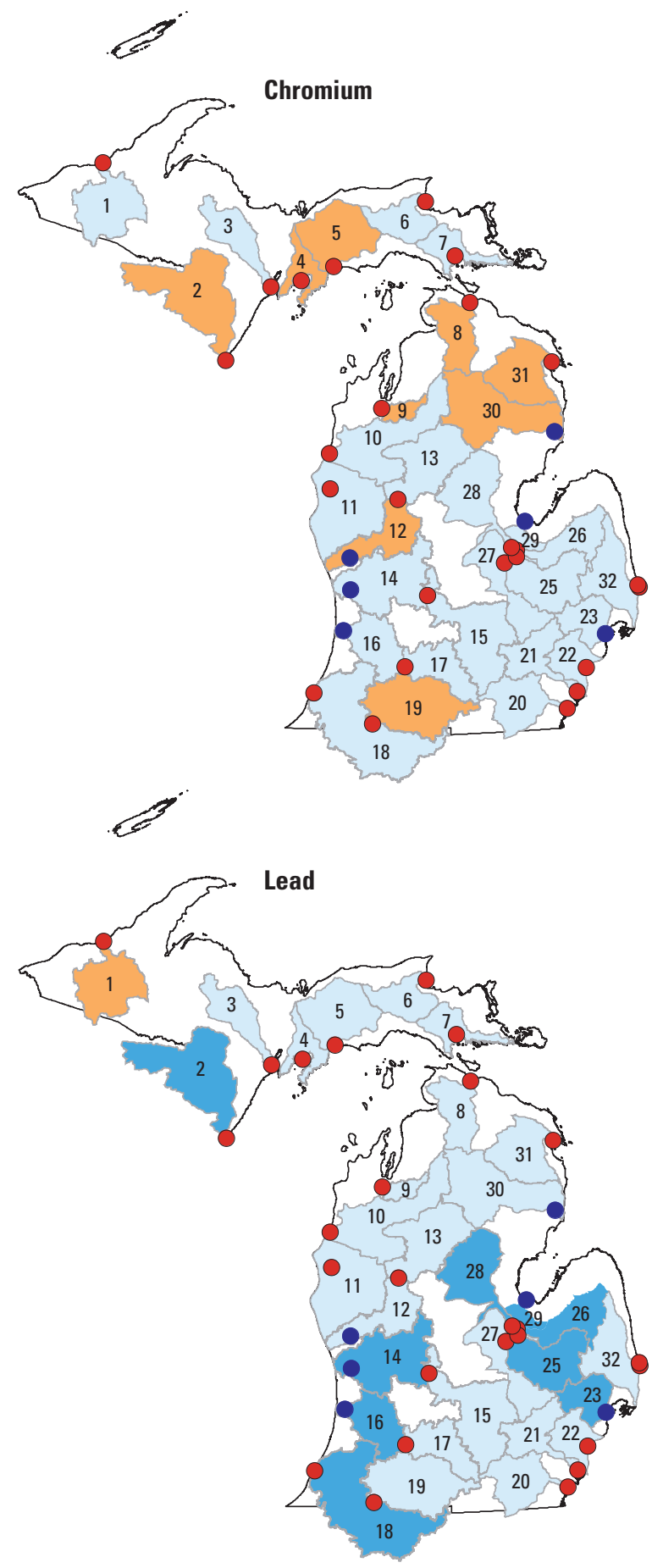

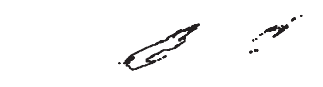
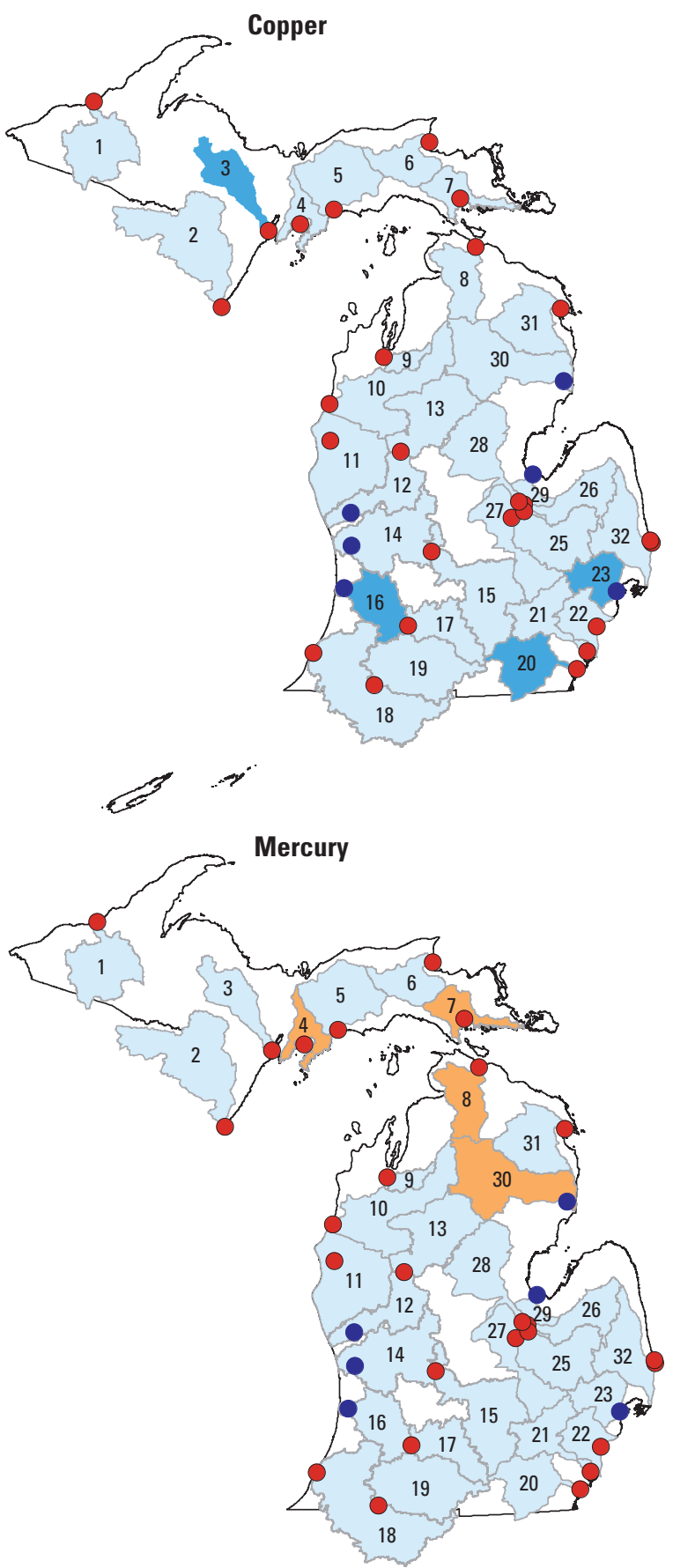

EXPLANATION

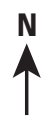

and the Watershed Boundary Dataset, 2017, 1:8,433,662 World Geodetic System, 1984

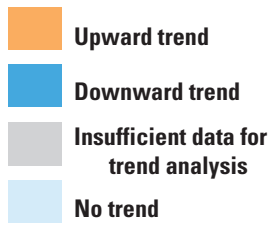

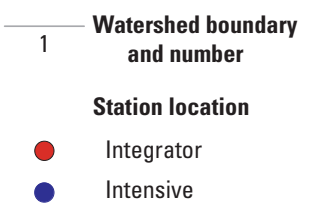

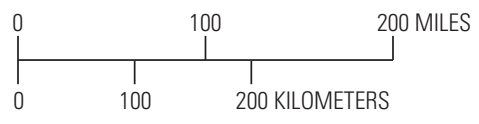

Figure 4. Trend results for chromium, copper, lead, and mercury by Michigan watershed. 
Kalamazoo (16), Raisin (20), and Clinton (23) Rivers at a rate of $3.32,1.37,2.32$, and 2.31 percent per year, respectively (appendix 1). The spatial distribution of copper trends in Michigan is shown in figure 4 . The downward trends are in the southern Lower Peninsula, with the exception of the Escanaba River (3) in the Upper Peninsula of the State. Similar to chromium, the maximum concentrations for the rivers with upward trends are still low (0.67 and 1.57 micrograms per liter). Similar to chromium, the copper Michigan Rule 57 waterquality criteria final chronic value is based on a waters hardness (Michigan Department of Environmental Quality, 2006b, 2016). For these streams with upward trends, the maximum concentrations were below the final chronic value for copper of 6.9 and 5.3 micrograms per liter, respectively.

Trends in lead were detected in 10 of 32 rivers analyzed (table 10). Again, the data distribution was such that the Seasonal Kendall test could be used for all analyses of trends. All but one of the trends were downward, indicating a general improvement in water quality with respect to lead. The one upward trend was for the Ontonagon River (1) at a rate of 3.83 percent per year. The nine downward trends were at the Menominee (2), lower Grand (14), lower Kalamazoo (16), lower St. Joseph (18), Clinton (23), Flint (25), Cass (26), Tittabawassee (28), and Saginaw (29) Rivers at rates of 1.80, $4.97,2.33,6.26,3.91,5.38,5.45,5.48$, and 5.27 percent per year, respectively (appendix 1). The spatial distribution of lead trends in Michigan is shown in figure 4. The only upward trend is in the northernmost sampled river in the Upper Peninsula. The downward trends are primarily in the Lower Peninsula, with the exception of the Menominee River (2). For lead, Michigan Rule 57 water-quality criteria final chronic value also is based on a waters hardness (Michigan Department of Environmental Quality, 2016). The maximum value (17 micrograms per liter) of the only upward trend for the Ontonagon River (1) did exceed the final chronic value of 15.6 micrograms per liter for that sample. However, the maximum value of lead for that sample (May 10, 2006) was related to a runoff event with high flow and elevated sediment and other metal constituents in the river. The lead concentrations for the Ontonagon River (1) did not exceed the Rule 57 final chronic value for lead in any other sample because the previously described conditions were not observed again.

Trends in mercury were estimated in 4 of the 32 rivers analyzed (table 10). The Seasonal Kendall test was used to analyze all rivers and four upward trends were detected. The upward trends were detected in the Sturgeon (4), Pine (7), Cheboygan (8), and Au Sable (30) Rivers at rates of $5.21,2.99,7.12$, and 3.43 percent per year, respectively (appendix 1). The spatial distribution of mercury trends in Michigan is shown in figure 4. The upward trends are in the Upper Peninsula and northern Lower Peninsula of the State. Maximum concentrations at the stations with increasing trends are still low, ranging from 1.43 to 45.05 nanograms per liter (appendix 1). Those values are below the Michigan Rule 57 water-quality criteria final chronic value for mercury of 770 nanograms per liter.

\section{Trend Summary}

During this study, samples were collected at 32 river sites, and for the constituents that were analyzed, 79 trends were detected -53 downward trends and 26 upward trends. The trend directions should be used in context with the constituent in deciding whether the trend indicates an improvement or impairment of a river. Trend results indicate that more constituents are declining (downward trend) than are increasing (upward trend); however, trend results do not necessarily indicate that the water quality in the State is improving. Rather, an examination of each constituent is needed to decide whether water quality in a river may be improving or degrading. For example, a downward trend in nutrient species might indicate improvement in water quality, whereas a downward trend in dissolved oxygen might indicate a decline in water quality.

In general, trends in nutrient species were downward; 30 of the 38 detected trends were downward. The most prevalent trend in nutrient species was for ammonia, with 11 downward trends and 1 upward trend. Trends in trace metals were not as uniform as the other constituents. Lead and copper trends were typically downward, whereas chromium and mercury trends were mainly upward.

Almost every river sampled had an estimated trend with the exception of the Tahquamenon River (6), which had no trends in any water-quality constituents. A summary of the number of trends and type of trend by watershed is shown in figure 5. Some particular rivers with trends indicating apparent improvement in water quality are the lower Grand (14), lower Kalamazoo (16), Raisin (20), and Clinton (23) Rivers. The lower Grand River (14) had estimated downward trends in TSS, ammonia, nitrite, TKN, and lead (tables 8-10). The lower Kalamazoo River (16) had downward trends in ammonia, TKN, copper, and lead (tables 9-10). The River Raisin (20) had downward trends in ammonia, nitrite, total phosphorus, and copper (tables 9-10). The Clinton River (23) had the most downward trends of any of the rivers studied with downward trends in TSS, ammonia, nitrite, total phosphorus, TKN, copper, and lead (tables 8-10). Trends common among these rivers were improvements in water quality resulting from decreases in nutrient and some trace metal concentrations during the study period.

In contrast, only one station had more than two upward trends, indicating an overall decline in water quality. The River Rouge (22) had upward trends in ammonia, nitrite, and nitrate. The declines in water quality for this river are associated with nutrient increases during the study period.

\section{Constituent Load Results}

Load estimates are a function of streamflow and constituent concentration in the stream. As such, the variability in streamflow is directly related to the variability in constituent load. Much of the variability seen in load estimates from year 


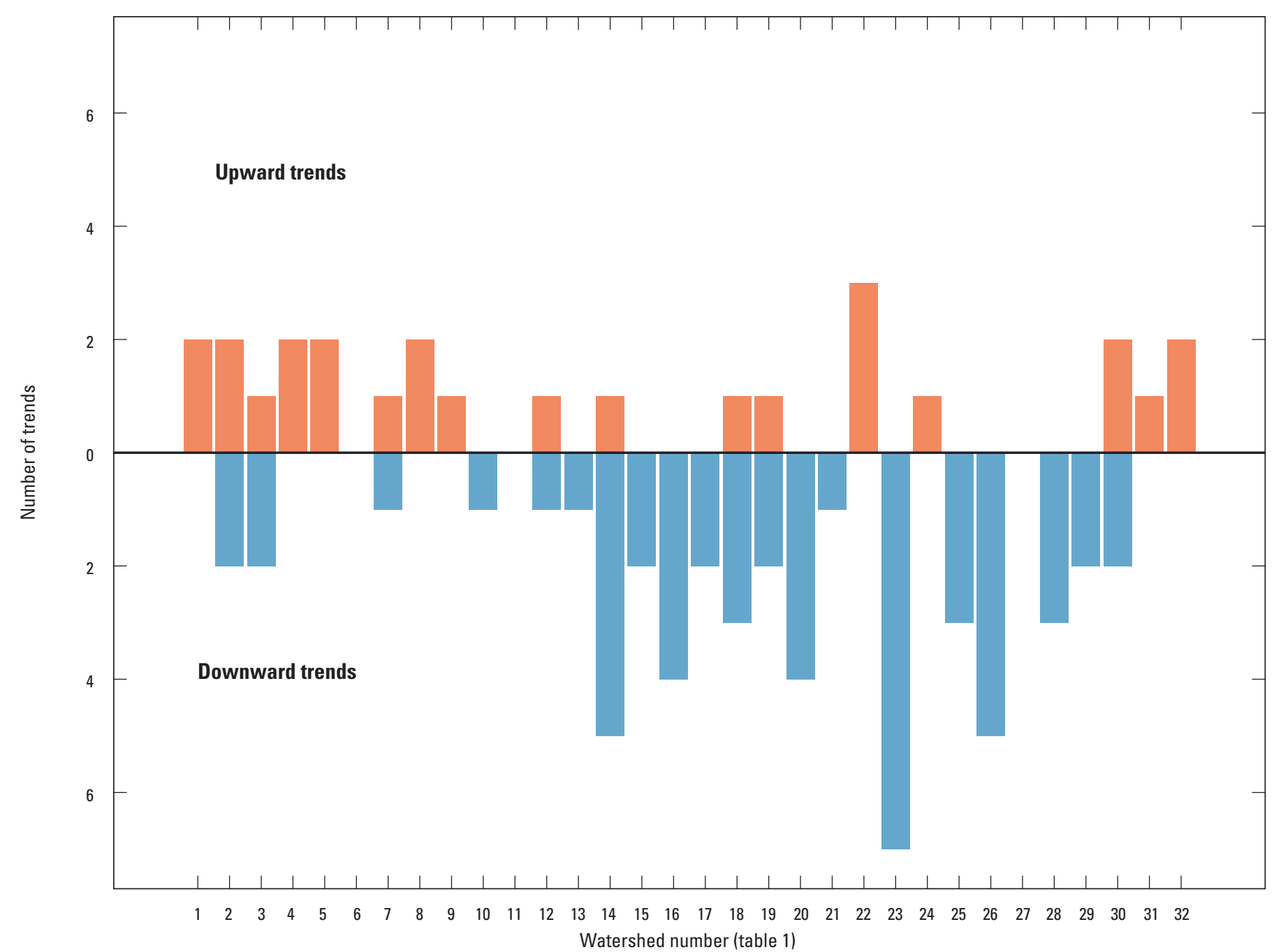

Figure 5. Number of upward and downward trends at Michigan stream stations.

to year is mostly because of variability in stream discharge. In addition, although large streams may have small concentrations of constituents in their water, the load may be high because of the large magnitude of flow that is discharged by that stream. For example, the Saginaw River (29) consistently has the maximum loads for the various constituents analyzed because it is one of the largest streams we analyzed in terms of streamflow.

Annual constituent loads were computed for chloride, TSS, total phosphorus, chromium, copper, lead, and mercury by using concentrations that were not flow adjusted at 31 stations throughout the study period (appendix 2). Annual loads were computed every year from 2002 to 2013 for the lower Kalamazoo (16), lower Grand (14), lower Muskegon (12), Au Sable (30), Clinton (23), and Saginaw (29) Rivers (referred to as the intensive stations), whereas load calculations for the remaining 25 stations were more irregular (tables 5 and 6). The number of stations analyzed for loads (31 stations) is not in conflict with the number of stations analyzed for trends (32 stations), as the Black River (32) only had loads estimated in
2006 and 2012. Thus, loads were only estimated for USGS station number 04160055 and not for the older USGS station number 04160075. In the Kalamazoo, Grand, and Muskegon River watersheds, where upstream and downstream locations were sampled, the ratio of the load in the upstream subwatershed to the total load computed at the mouth of the stream lower watershed was determined. To account for difference in drainage areas, yields (loads/drainage area) also were determined where annual loads were calculated.

\section{Annual Loads and Yields for Chloride, Total Suspended Solids, and Total Phosphorus}

Annual variability was observed most prominently at the stations with the highest loads (figs. 6-8). The annual loads are primarily driven by flow in each of these watersheds and wetter years where annual flows were higher (fig. 9); total phosphorus, TSS, and chloride also were higher. Summary statistics for annual loads at the six stations that 

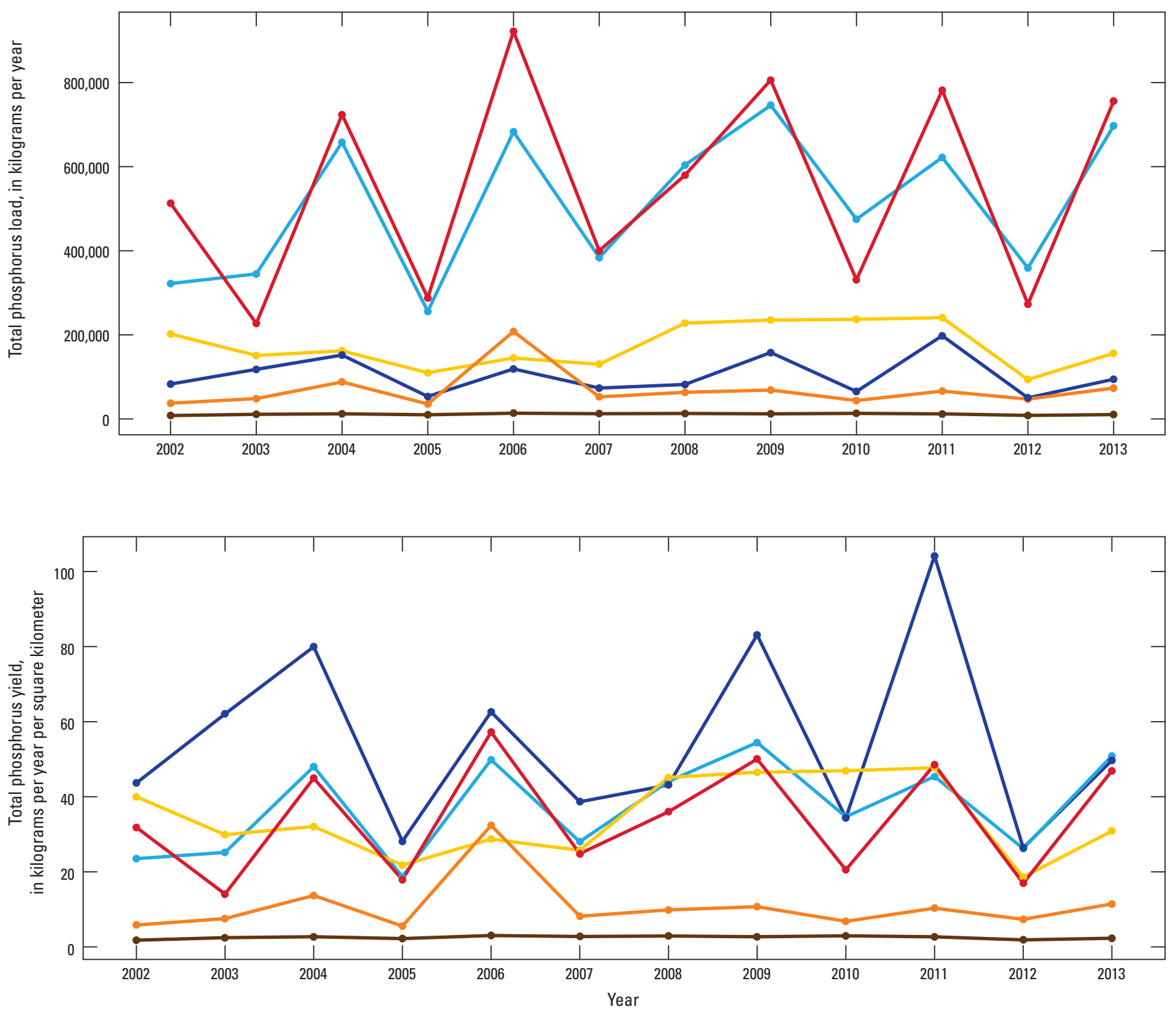

EXPLANATION

$\multimap$ Au Sable River near Au Sable, Michigan (30)

$\multimap$ Clinton River at Gratiot Avenue at Mt. Clemens, Michigan (23)

- Grand River near Eastmanville, Michigan (lower) (14)

- Kalamazoo River at New Richmond, Michigan (lower) (16)

$\longrightarrow$ Muskegon River near Bridgeton, Michigan (lower) (12)

$\multimap$ Saginaw River at Weadock Road at Essexville, Michigan (29)

Figure 6. Annual total phosphorus loads (top) and yields (bottom) for six intensively monitored rivers, 2002-13. 

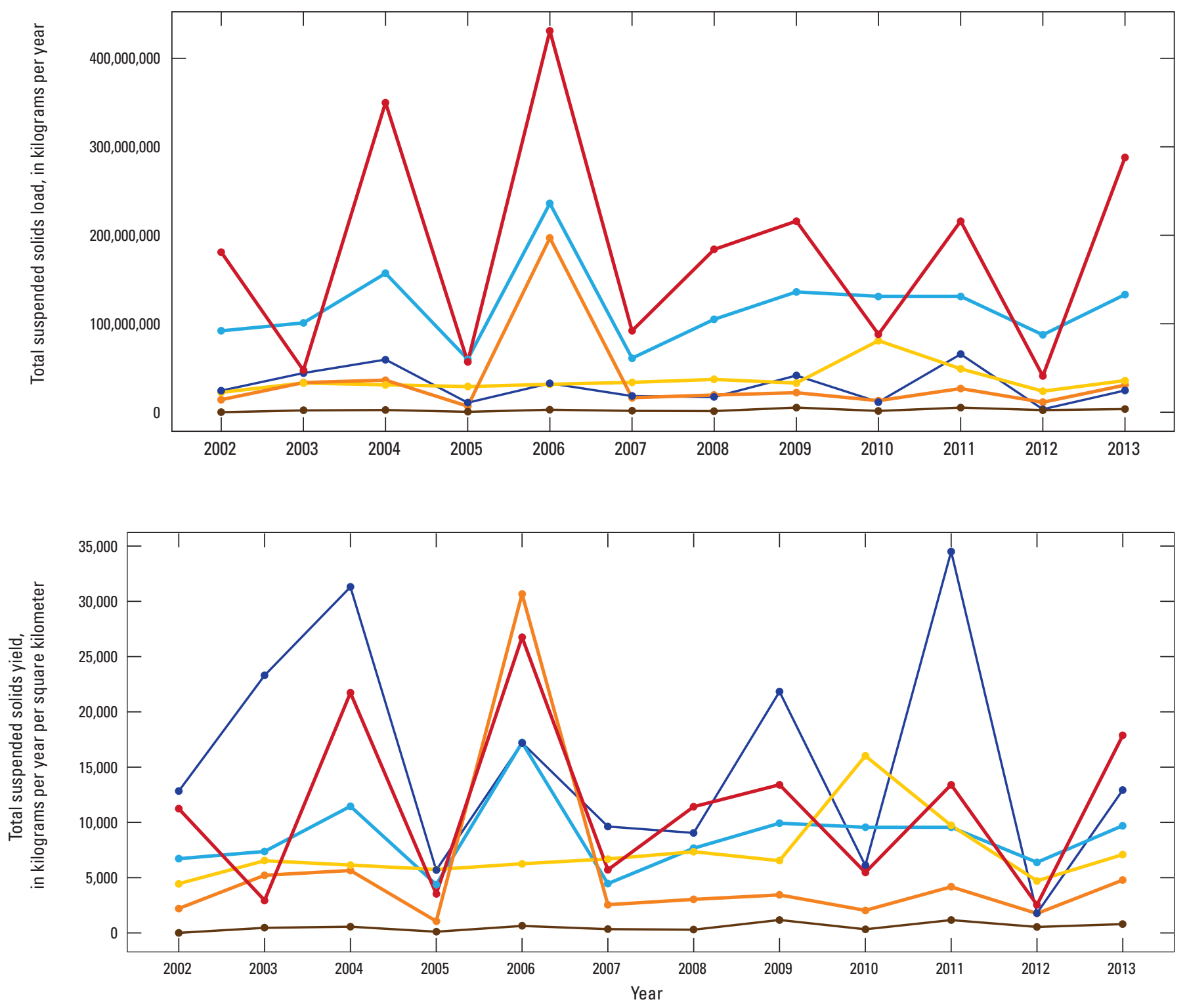

EXPLANATION

$\rightarrow$ Au Sable River near Au Sable, Michigan (30)

$\multimap$ Clinton River at Gratiot Avenue at Mt. Clemens, Michigan (23)

- Grand River near Eastmanville, Michigan (lower) (14)

- Kalamazoo River at New Richmond, Michigan (lower) (16)

$\rightarrow$ Muskegon River near Bridgeton, Michigan (lower) (12)

$\multimap$ Saginaw River at Weadock Road at Essexville, Michigan (29)

Figure 7. Annual total suspended solids (top) and yields (bottom) for six intensively monitored rivers, 2002-13. 

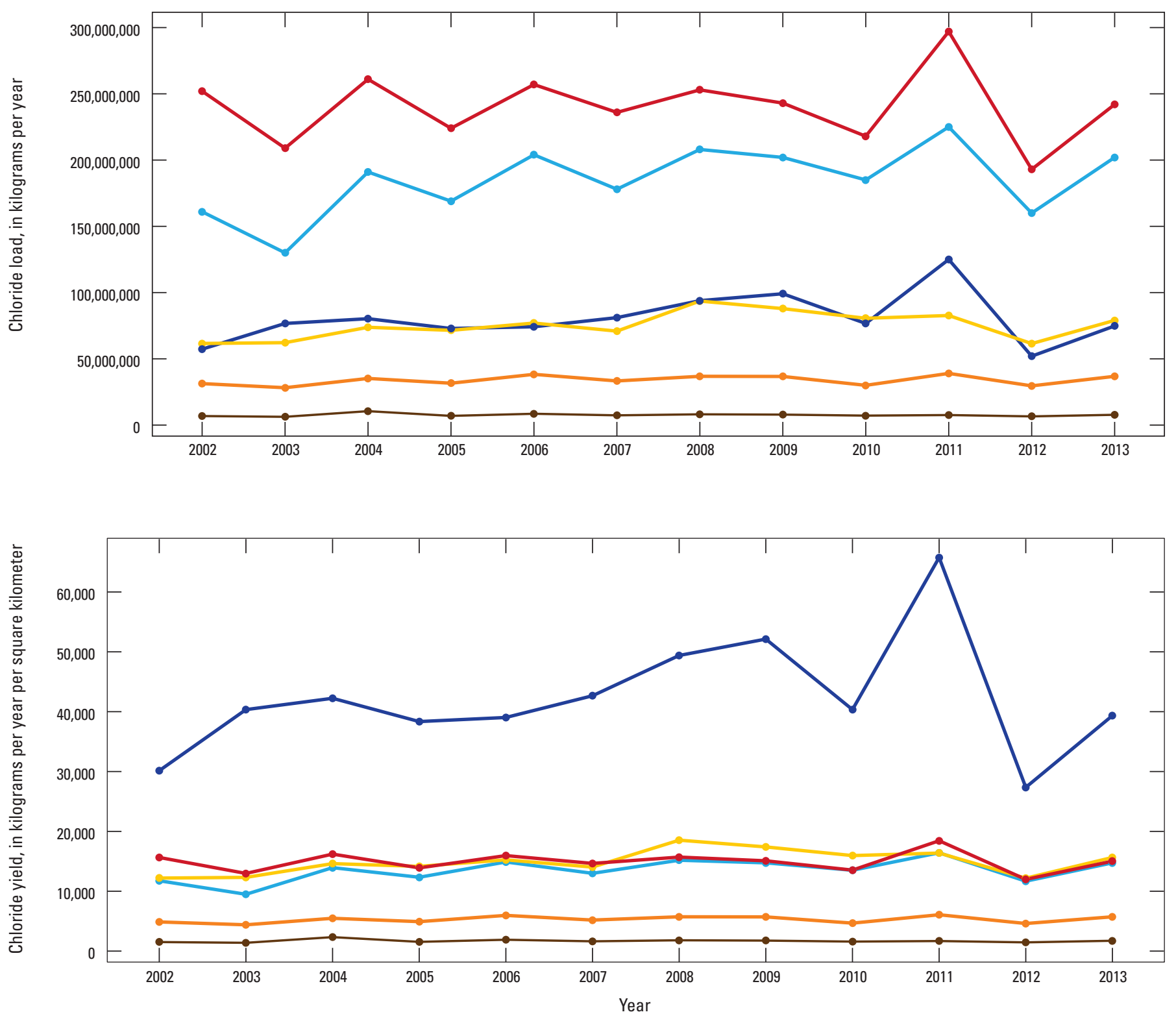

EXPLANATION

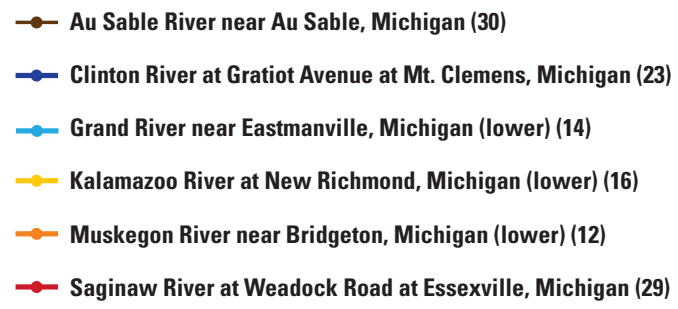

Figure 8. Annual chloride loads (top) and yields (bottom) for six intensively monitored rivers, 2002-13. 


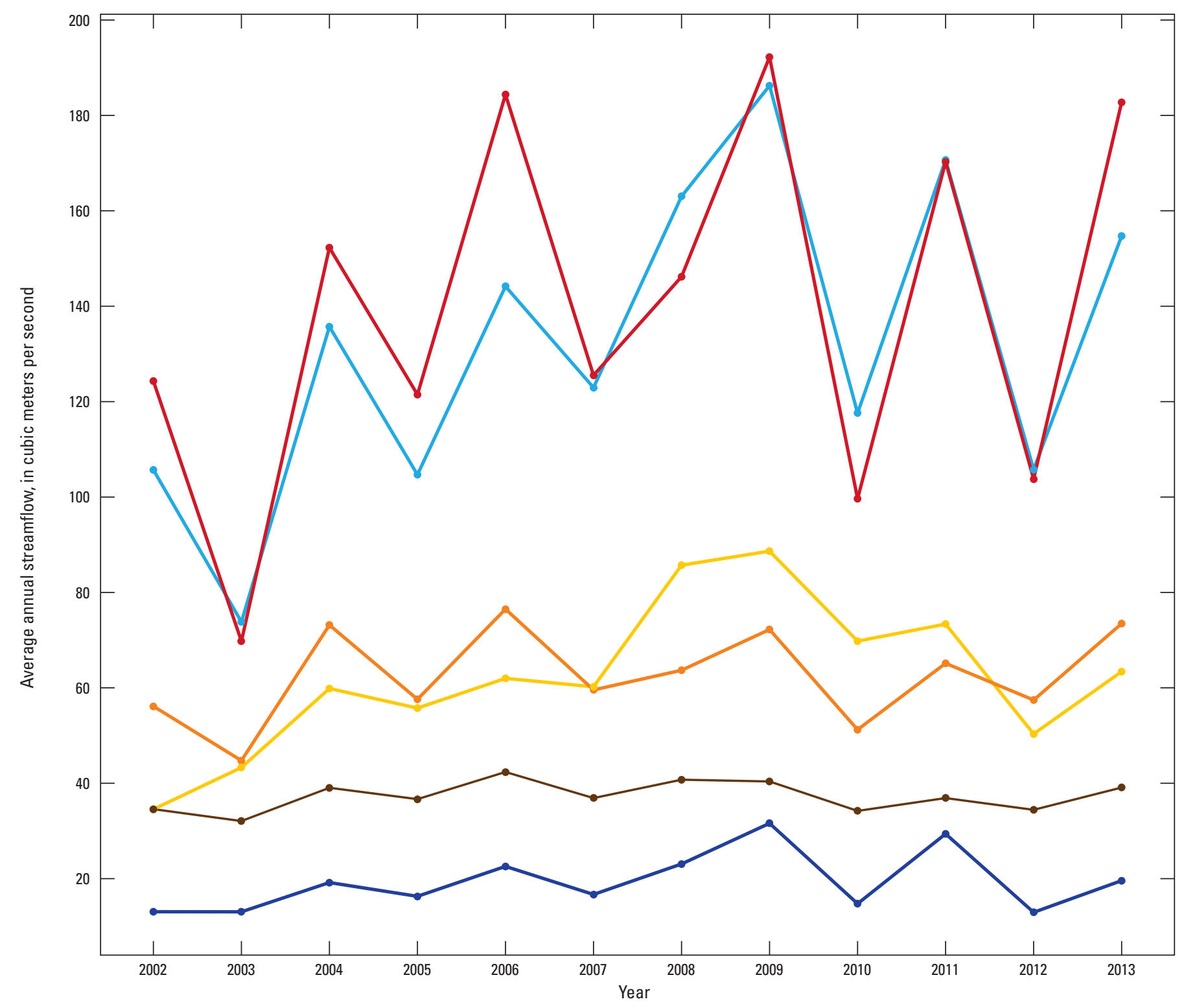

EXPLANATION

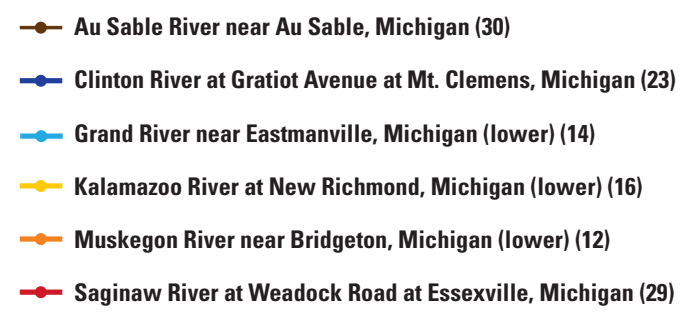

Figure 9. Annual average streamflow for six intensively monitored rivers, 2002-13. 
had 12 years of annual data from 2002 to 2013-lower Muskegon (12), lower Grand (14), lower Kalamazoo (16), Clinton (23), Saginaw (29), and Au Sable (30) Rivers - are listed in table 11 . Out of the six intensively monitored stations, the annual loads for chloride, TSS, and total phosphorus were largest for the Saginaw (29) and Grand (14) Rivers, which also represent the largest drainage areas (16,110 and 13,701 square kilometers $\left[\mathrm{km}^{2}\right]$, respectively). In 2006, the Saginaw River (29) had the largest annual load estimates for TSS (431 million kilograms per year [kg/yr]) and total phosphorus $(922,000 \mathrm{~kg} / \mathrm{yr})$. The Saginaw River (29) also had the largest chloride loads, 216 million kg/yr in 2011. The Saginaw River (29) watershed is a large watershed dominated by agricultural land use (fig. 1) often a source for sediment and phosphorus. In contrast, the Au Sable (30) River (4,504 km²) and Muskegon River (12) $\left(6,423 \mathrm{~km}^{2}\right)$ typically had the lowest annual loads for all three constituents. Both of the watersheds are in the northern portion of the Lower Peninsula dominated by undeveloped land use (fig. 1). In 2002, the Au Sable River (30) had the lowest estimated load for TSS and total phosphorus $(29,800 \mathrm{~kg} / \mathrm{yr}$ and $8,070 \mathrm{~kg} / \mathrm{yr}$, respectively). In 2003, the Au Sable River (30) had the lowest chloride load $(6,230,000 \mathrm{~kg} / \mathrm{yr})$. These results are consistent with other Great Lake studies that have determined land use and drainage area have a significant influence on sediment and phosphorus loads (Robertson and Saad, 2011; Hayhurst and others, 2016).

To account for the different drainage area, yields were determined by dividing the annual load (kilogram per year) by the drainage area (square kilometers). The results for all studies stations are listed in appendix 2. Summary statistics and results for the intensive stations are listed in table 11 and shown in figures 6-8. The Clinton River (23) had the highest yield for chloride $(65,753$ kilograms per year per square kilometer $\left.\left[\mathrm{kg} / \mathrm{yr} / \mathrm{km}^{2}\right]\right)$, total phosphorus $\left(104.5 \mathrm{~kg} / \mathrm{yr} / \mathrm{km}^{2}\right)$, and TSS $\left(34,507 \mathrm{~kg} / \mathrm{yr} / \mathrm{km}^{2}\right)$ all in 2011 . However, out of the dataset the Ontonagon River (1) had the greatest TSS yields (appendix 2). The lowest yields for total phosphorus and TSS were at the Au Sable River (30) in 2002 (about 1.8 and $7 \mathrm{~kg} / \mathrm{yr} / \mathrm{km}^{2}$, respectively). For chloride, several rivers had lower yields than the lowest intensive station; the Au Sable River (30) in 2003. The rivers include the Sturgeon (4), Ontonagon (1), Manistique (5), Tahquamenon (6), Thunder Bay (31), Pine (7), and Menominee (2) Rivers.

Although the Clinton River (23) had moderate loads compared to larger drainage areas of the Saginaw (29) and Grand (14) Rivers, the yield of chloride was considerably higher than all of the other intensively monitored stations (fig. 8). The Clinton River (23) average annual yield for chloride was $42,257 \mathrm{~kg} / \mathrm{yr} / \mathrm{km}^{2}$ compared to the next highest of $14,924 \mathrm{~kg} / \mathrm{yr} / \mathrm{km}^{2}$ at the Saginaw River (29) (table 11). The Clinton River (23) also had higher average total phosphorus and TSS yields compared to the other five intensively monitored stations.

\section{Annual Loads of Trace Metals}

Annual loads for the trace metals (chromium, copper, lead, and mercury) follow similar patterns to TSS and total phosphorus at the intensive stations (table 12). The Saginaw (29) and lower Grand (14) Rivers had the largest annual loads for all four metals; again, these rivers also represent larger drainage areas. When considering drainage areas, results indicate the Clinton River (23) has the highest yields for each of the trace metals.

From 2002 to 2013, the maximum chromium load observed during was $18,700 \mathrm{~kg} / \mathrm{yr}$ in the Ontonagon River (1) in 2008 (appendix 2). The greatest observed loads were in the Ontonagon (1), Saginaw (29), and lower Grand (14) Rivers; the Saginaw River (29) had 6 of the 10 highest chromium loads within the dataset. The minimum chromium load observed in Michigan was $4.4 \mathrm{~kg} / \mathrm{yr}$ in the Au Sable River (30) in 2003. The 10 lowest observed loads were in the Au Sable (30), Boardman (9), Cheboygan (8), Thunder Bay (31), Pere Marquette (11), Shiawassee (27), and Sturgeon (4) Rivers.

During the study period, the maximum cooper load was 19,400 kg/yr observed in the Saginaw River (29) in 2006 (appendix 2). The greatest copper loads were observed in the Saginaw (29), Ontonagon (1), and lower Grand (14) Rivers. The minimum observed copper load was $51 \mathrm{~kg} / \mathrm{yr}$ in the Boardman River (9) in 2003. The lowest observed loads of copper were observed in the Boardman (9), Sturgeon (4), Au Sable (30), and Thunder Bay (31) Rivers.

The maximum annual load of lead was $15,800 \mathrm{~kg} / \mathrm{yr}$ in the Saginaw River (29) in 2006 (appendix 2). The greatest observed loads were in the Saginaw (29) and lower Grand (14) Rivers. The minimum annual load of lead observed was $28 \mathrm{~kg} / \mathrm{yr}$ in the Au Sable River (30) in 2010. The smallest observed loads of lead during the study period were in the Au Sable (30), Sturgeon (4), Boardman (9), Cheboygan (8), and Thunder Bay (31) Rivers.

The maximum load of mercury was $69.4 \mathrm{~kg} / \mathrm{yr}$ in the Saginaw River (29) in 2006 (appendix 2). The greatest observed loads during the study were in the Saginaw (29), lower Grand (14), and Menominee (2) Rivers. The minimum load of mercury was $0.34 \mathrm{~kg} / \mathrm{yr}$, in the Au Sable River (30) in 2010. Rivers with the smallest loads of mercury included the Au Sable (30), Boardman (9), Shiawassee (27), and Cheboygan (8) Rivers.

\section{Comparison of Upper and Lower Watershed Yields}

During the WCMP study, contributing subwatersheds were sampled in the same year for three of the major river basins; Kalamazoo, Grand, and Muskegon. Yields were compared at the upper watershed and lower watershed for chloride, TSS, and total phosphorus to determine if major load contributions differed in these large watersheds (fig. 10). 


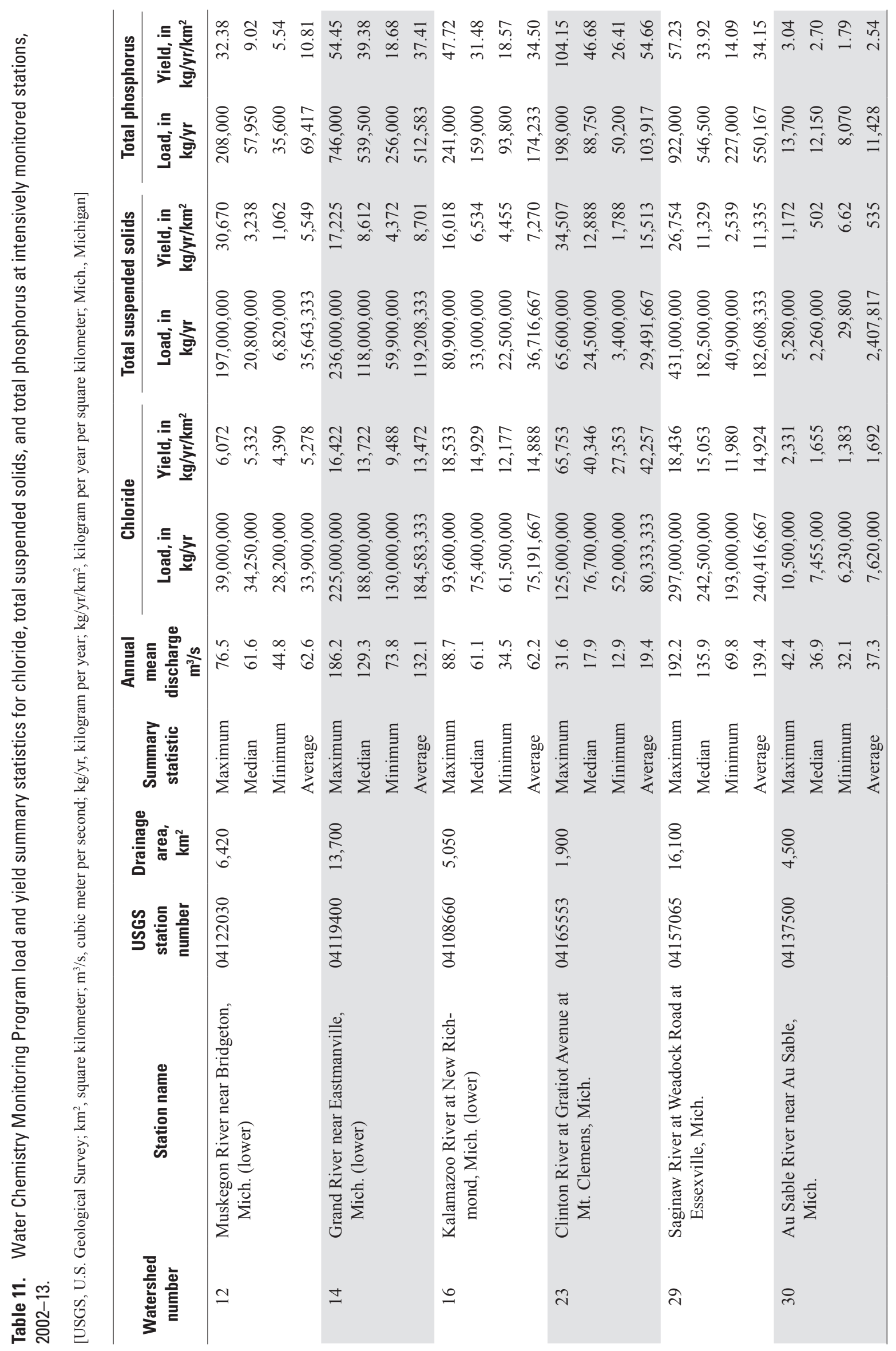




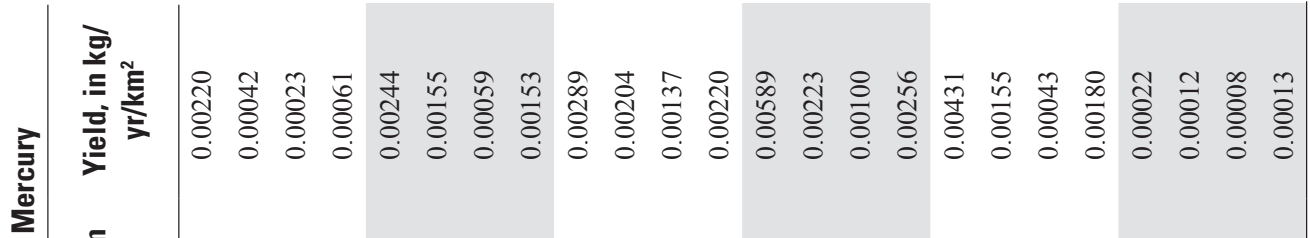

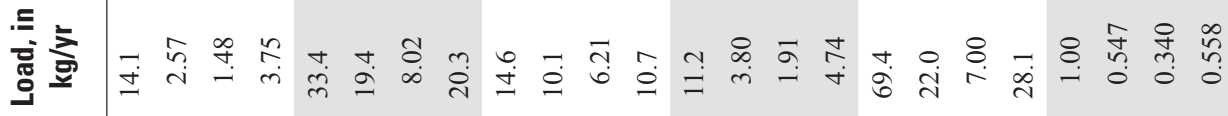

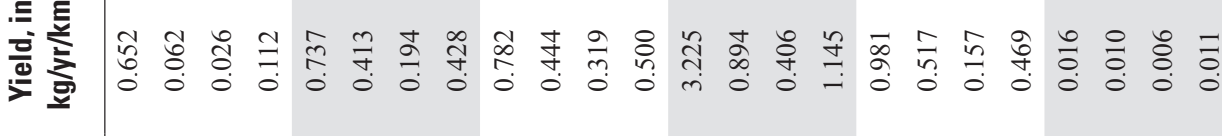

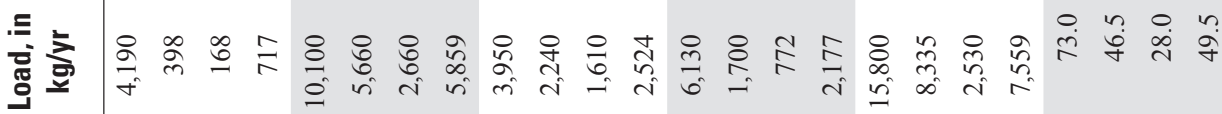

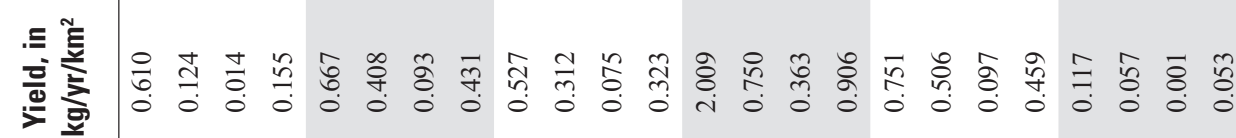

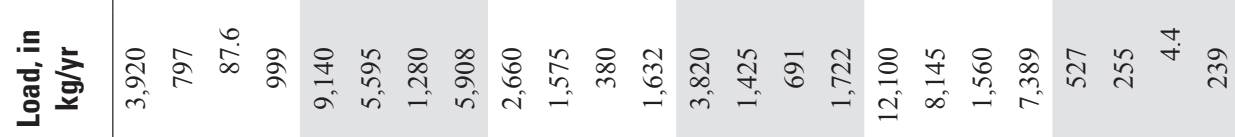

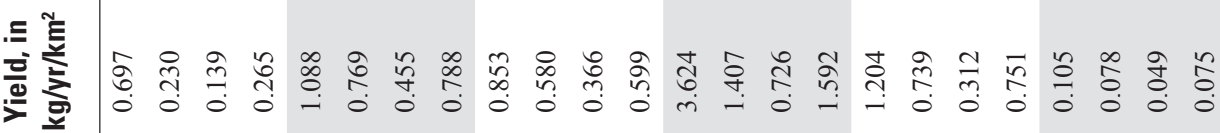

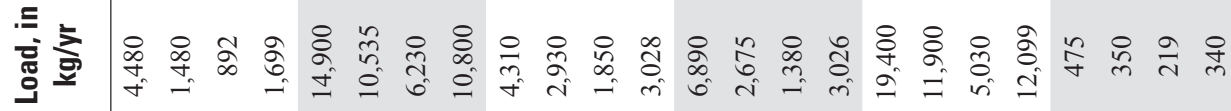

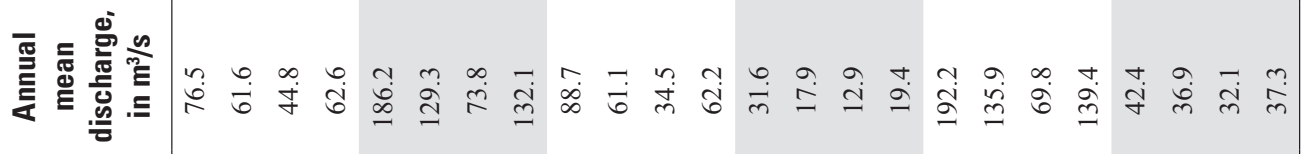

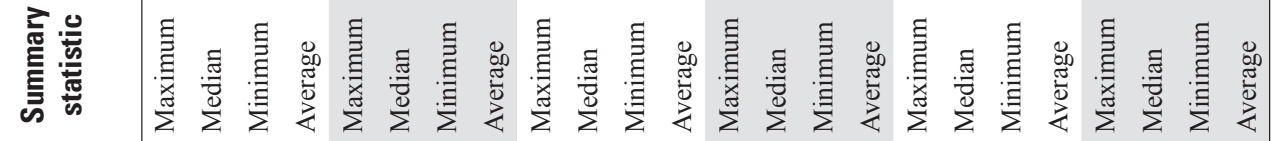

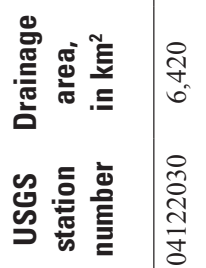

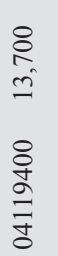

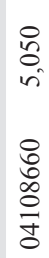

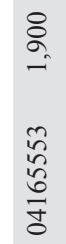

8
0
0
0
8
$\frac{8}{8}$
$\frac{7}{0}$

8
$\stackrel{0}{+}$
+
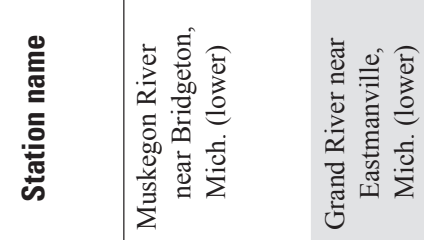

离营

$\stackrel{8}{\circ} \cdot \frac{2}{2}$

氙

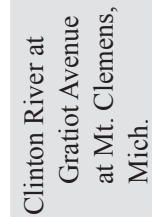

?

กิ

ते

\&

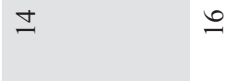



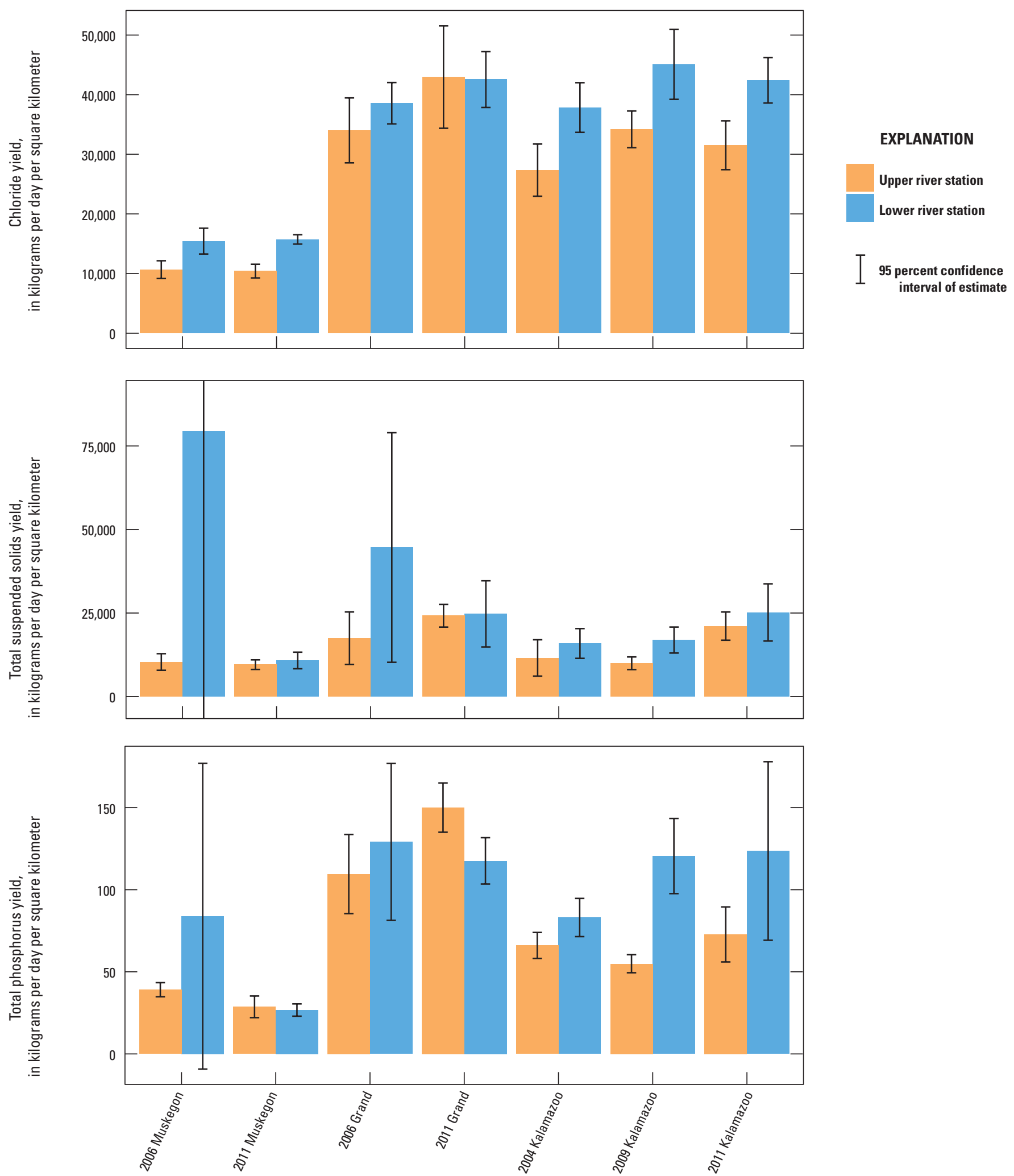

Figure 10. Comparison of chloride (top), total suspended solids (middle), and total phosphorus (bottom) yields for lower and upper watershed sampling locations. 
The TSS and total phosphorus yields were similar at the upper and lower watershed with a couple exceptions. Yields seemed to be higher in 2006 at the lower Muskegon River (12); however, the load estimation had a large uncertainty and, therefore, a true difference was difficult to determine. A single event on March 13, 2006, at the lower Muskegon River (12) (USGS station 04122030, Muskegon River near Bridgeton, Mich.) resulted in a sample being collected with higher flows and higher concentrations. This biased the annual load for this station, resulting in a large uncertainty value. In 2009, the TSS yield was slightly higher at the lower Kalamazoo River (16) compared to the upper station; otherwise yields were within error estimation. Similar results also were seen for total phosphorus where yields for most comparisons were similar. Exceptions were in 2011 in the Grand River where a higher yield was in the upper watershed (15) and in 2009 in the Kalamazoo River where a higher yield was in the lower watershed (16). Although loads may be greater downstream in the watershed (appendix 2), when drainage area is considered, yields are similar for these stations on the years where comparisons could be made.

Chloride yields were greater at the lower watershed location for the Muskegon and Kalamazoo Rivers than the upper watershed location. These yield results were not similar for the Grand River watershed. The lower Kalamazoo River (16) had about 10,000 kilograms per day per square kilometer greater yield for chloride than the upper Kalamazoo River (17) for all three sampling dates during the study period. Similarly, the lower Muskegon River (12) had greater yields than the upper Muskegon River (13) for both sampling dates during the study period. The difference in chloride yields could be a result of several factors including land-use nonpoint source such as runoff from land surfaces or point sources such as wastewater effluent. Unlike suspended sediment and particulate phosphorus, chloride is often a dissolved constituent that is more conservative so removal from the system by physical or biological processes is less likely. Therefore, chloride could be accumulating in the river as it moves downstream. Further studies would be needed to determine the source or reasons for difference in the watershed.

\section{Summary}

In 1998, the Michigan Department of Environmental Quality and the U.S. Geological Survey began the Water Chemistry Monitoring Program for select streams in the State of Michigan. Objectives of this program were to provide assistance with (1) statewide water-quality assessments, (2) the National Pollutant Discharge Elimination System permitting process, and (3) water-resource management decisions. As part of this program, water-quality data collected from 1998 to 2013 were analyzed to identify potential trends in waterquality constituents and estimate constituent loads from select streams in Michigan.
Water-quality data from 32 rivers sampled as part of the Water Chemistry Monitoring Program were analyzed for trends in ammonia, chloride, chromium, copper, lead, mercury, nitrate, nitrite, orthophosphate, total phosphorus, total Kjeldahl nitrogen, and total suspended solids. Trend analysis on the various water-quality data in the form of flow-adjusted concentrations was done using either the uncensored Seasonal Kendall test, or through Tobit regression. Trend analysis identified 79 trends in water-quality constituents among the 32 river stations analyzed -53 downward trends and 26 upward trends were identified in the water-quality dataset. The most prevalent trend throughout Michigan streams was a downward trend for ammonia, primarily in the Lower Peninsula of Michigan. Several river stations analyzed for trends indicate an improvement in water quality during the study period and include the lower Grand, lower Kalamazoo, Raisin, and Clinton Rivers. However, trends in water-quality constituents indicate a decline in water quality at the Rouge River during the study period.

In addition to trends, constituent loads were estimated for 31 stations from 2002 to 2013 for stations that were sampled 12 times per year. Loads were computed using the Autobeale load computation program, which used the Beale ratio estimator approach to estimate an annual load. Constituent loads were the largest in large watershed streams with the highest annual flows such as the Saginaw and Grand Rivers. Likewise, constituent loads were the smallest in smaller tributaries that were sampled as part of this program such as the Boardman and Thunder Bay Rivers. Rivers with paired upstream and downstream sampling locations were assessed to identify percent contribution of load on years when loads were estimated at both river stations.

Using the data from the Water Chemistry Monitoring Program, the trend and load analysis developed in this study can be used to identify areas that are improving and degrading with respect to water quality in the State of Michigan. Identification of watersheds will enable water-resource managers to further study these watersheds and determine factors that are contributing to the improvement or decline in water quality. In addition, the information can assist in developing strategies to meet Great Lakes goals in improving water-quality and mitigating issues in the Great Lakes basin such as harmful algal blooms and lake hypoxia. The continued monitoring and analysis of water quality of streams in Michigan will be helpful in assessing the effectiveness of any strategies employed to address water-quality issues.

\section{References Cited}

Archfield, S.A., and Vogel, R.M., 2010, Map correlation method-Selection of a reference streamgage to estimate daily streamflow at ungaged catchments: Water Resources Research, v. 46, no. 10, 15 p. 
Bonn, B.A., 2008, Using the U.S. Geological Survey National Water Quality Laboratory LT-MDL to evaluate and analyze data: U.S. Geological Survey Open-File Report 2008-1227, $73 \mathrm{p}$.

Cohn, T.A., 1988, Adjusted maximum likelihood estimation of the moments of lognormal populations from type I censored samples: U.S. Geological Survey Open-File Report 88-350, $34 \mathrm{p}$.

Dolan, D.M., and Chapra, S.C., 2012, Great Lakes total phosphorus revisited-1. Loading analysis and update (1994-2008): Journal of Great Lakes Research, v. 38, no. 4, p. $730-740$.

Hayhurst, B.A., Fisher, B.N., and Reddy, J.E., 2016, Streamflow and estimated loads of phosphorus and dissolved and suspended solids from selected tributaries to Lake Ontario, New York, water years 2012-14: U.S. Geological Survey Scientific Investigations Report 2016-5084, 34 p., accessed October 3, 2017, at https://dx.doi.org/10.3133/sir20165084.

Hem, J.D., 1985, Study and interpretation of the chemical characteristics of natural water: U.S. Geological Survey Water Supply Paper 2254, 263 p.

Helsel, D.R., and Hirsch, R.M., 2002. Statistical methods in water Resources: U.S. Geological Survey Techniques of Water Resources Investigations, book 4, chap. A3, 522 p.

Hirsch, R.M., Alexander, R.B., and Smith, R.A., 1991, Selection of methods for the detection and estimation of trends in water quality: Water Resources Research, v. 27, no. 5, p. $803-813$.

Hirsch, R.M., Slack, J.R., and Smith, R.A, 1982, Techniques of trend analysis for monthly water quality data: Water Resources Research, v. 18, no. 1, p. 107-121.

Hoard, C.J., Fuller, L.M., and Fogarty, L.R., 2009, Analysis of water-quality trends for selected streams in the Water Chemistry Monitoring Program, Michigan, 1998-2005: U.S. Geological Survey Scientific Investigations Report 2009-5216, 48 p.

Homer, C.G., Dewitz, J.A., Yang, L., Jin, S., Danielson, P., Xian, G., Coulston, J., Herold, N.D., Wickham, J.D., and Megown, K., 2015, Completion of the 2011 National Land Cover Database for the conterminous United StatesRepresenting a decade of land cover change information: Photogrammetric Engineering and Remote Sensing, v. 81, no. 5 , p. 345-354.

International Joint Commission, 2014, A balanced diet for Lake Erie-Reducing phosphorus loadings and harmful algal blooms: accessed January 5, 2016, at http://www.ijc. org/files/publications/2014\%20IJC\%20LEEP\%20REPORT. pdf.
Michigan Department of Environmental Quality, 2001, Michigan water chemistry trend monitoring 1998-1999 report: MI/DEQ/SWQ-02/025, accessed October 25, 2017, at http://www.michigan.gov/documents/deq/wb-swas9899trendreport_254158_7.pdf.

Michigan Department of Environmental Quality, 2002, Michigan water chemistry trend monitoring 2000 report: MI/DEQ/SWQ-02/092, accessed June 20, 2008, at http:// www.michigan.gov/documents/deq/wb-swas-2000trendreport_254165_7.pdf.

Michigan Department of Environmental Quality, 2003, Michigan water chemistry monitoring 2001 report: MI/ DEQ/WD-03/085, accessed June 20, 2008, at http://www. michigan.gov/documents/deq/wb-swas-2001 trendreport_254179_7.pdf.

Michigan Department of Environmental Quality, 2004, Michigan water chemistry monitoring Great Lakes tributaries 2002 report: MI/DEQ/WD-04/049, accessed June 20, 2008, at http://www.michigan.gov/documents/deq/wrd-swas2002trendreport_445640_7.pdf.

Michigan Department of Environmental Quality, 2005, Michigan water chemistry monitoring Great Lakes tributaries 2003 report: MI/DEQ/WD-05/058, accessed June 20, 2008, at http://www.michigan.gov/documents/deq/wrd-swas-03tribreport_445635_7.pdf.

Michigan Department of Environmental Quality, 2006a, Michigan water chemistry monitoring Great Lakes tributaries 2004 report: MI/DEQ/WD-06/045, accessed June 20, 2008, at http://www.michigan.gov/documents/deq/wrdswas-04tribreport_445636_7.pdf.

Michigan Department of Environmental Quality, 2006b, Part 4-Water quality standards: accessed October 2, 2015, at http://www.michigan.gov/documents/deq/wrd-rulespart4_521508_7.pdf.

Michigan Department of Environmental Quality, 2008, Michigan water chemistry monitoring Great Lakes tributaries 1998-2005 report: MI/DEQ/WB-08/014, accessed June 20, 2008, at http://www.michigan.gov/documents/deq/wb-swas9805tribreport_222804_7.pdf.

Michigan Department of Environmental Quality, 2013, Michigan's water chemistry monitoring program-A report of statewide spatial patterns 2005-2009 and fixed stations status and trends 1998-2008: MI/DEQ/WRD-13/005, accessed February 22, 2016, at http://www.michigan.gov/ documents/deq/wrd-swas-wcmp-0509report_431945_7.pdf.

Michigan Department of Environmental Quality, 2016, Rule 57 Water Quality Values: Michigan Department of Environmental Quality website, accessed January 4, 2016, at http://www.michigan.gov/deq/0,4561,7-1353313_3681_3686_3728-11383-,00.html. 
Michigan Department of Environmental Quality, 2017, Water quality parameter information page: accessed May 20, 2017, at http://www.michigan.gov/documents/deq/wrdnpdes-water-quality_570237_7.pdf.

Richards, R.P., Baker, D.B., Kramer, J.W., and Ewing, D.E., 1996, Annual loads of herbicides in Lake Erie tributaries of Michigan and Ohio: Journal of Great Lakes Research, v. 22, no, 2, p. 414-428.

Robertson, D.M., and Saad, D.A., 2011, Nutrient inputs to the Laurentian Great Lakes by source and watershed estimated using SPARROW watershed models: Journal of the American Water Resources Association, v. 47, no. 5, p. 1011-1033, accessed October, 3, 2017, at https://doi. $\operatorname{org} / 10.1111 / \mathrm{j} .1752-1688.2011 .00574 . x$.

Roush, Dawn, 2013, Michigan's Water Chemistry Monitoring Program - A report of statewide spatial patterns 2005-2009 and fixed station status and trends 1998-2008: Michigan Department of Environmental Quality Report MI/DEQ/WRD-13/005, 131 p. [Also available at http:// www.michigan.gov/documents/deq/wrd-swas-wcmp0509report_431945_7.pdf.]

Schertz, T.L., Alexander, R.B., and Ohe, D.J., 1991, The computer program Estimate TREND (ESTREND), a system for the detection of trends in water-quality data: U.S. Geological Survey Water-Resources Investigations Report 91-4040, $68 \mathrm{p}$.
Slack, J.R., Lorenz, D.L., and others, 2003, USGS library for S-PLUS for Windows-Release 2.1: U.S. Geological Survey Open-File Report 2003-357, accessed October 23, 2017, at https://pubs.er.usgs.gov/usgspubs/ofr/ofr03357.

State of Michigan, 2017, GIS open data portal website: accessed October 29, 2017, at http://gis-michigan.opendata. $\operatorname{arcgis.com} /$.

U.S. Environmental Protection Agency, 2016, Drinking water contaminants - Standards and regulations: U.S. Environmental Protection Agency website, accessed January 4, 2015, at http://www.epa.gov/dwstandardsregulations.

U.S. Environmental Protection Agency, 2017, Nutrient pollution website: accessed January 25, 2017, at https://www. epa.gov/nutrientpollution.

Watershed Boundary Dataset for Michigan, 2017, accessed April 15, 2017, at https://nrcs.app.box.com/v/huc.

Westjohn, D.B., and Weaver, T.L., 1998, Hydrogeologic framework of the Michigan Basin regional aquifer system: U.S. Geological Survey Professional Paper 1418, 47 p. 

Appendixes 1-2 


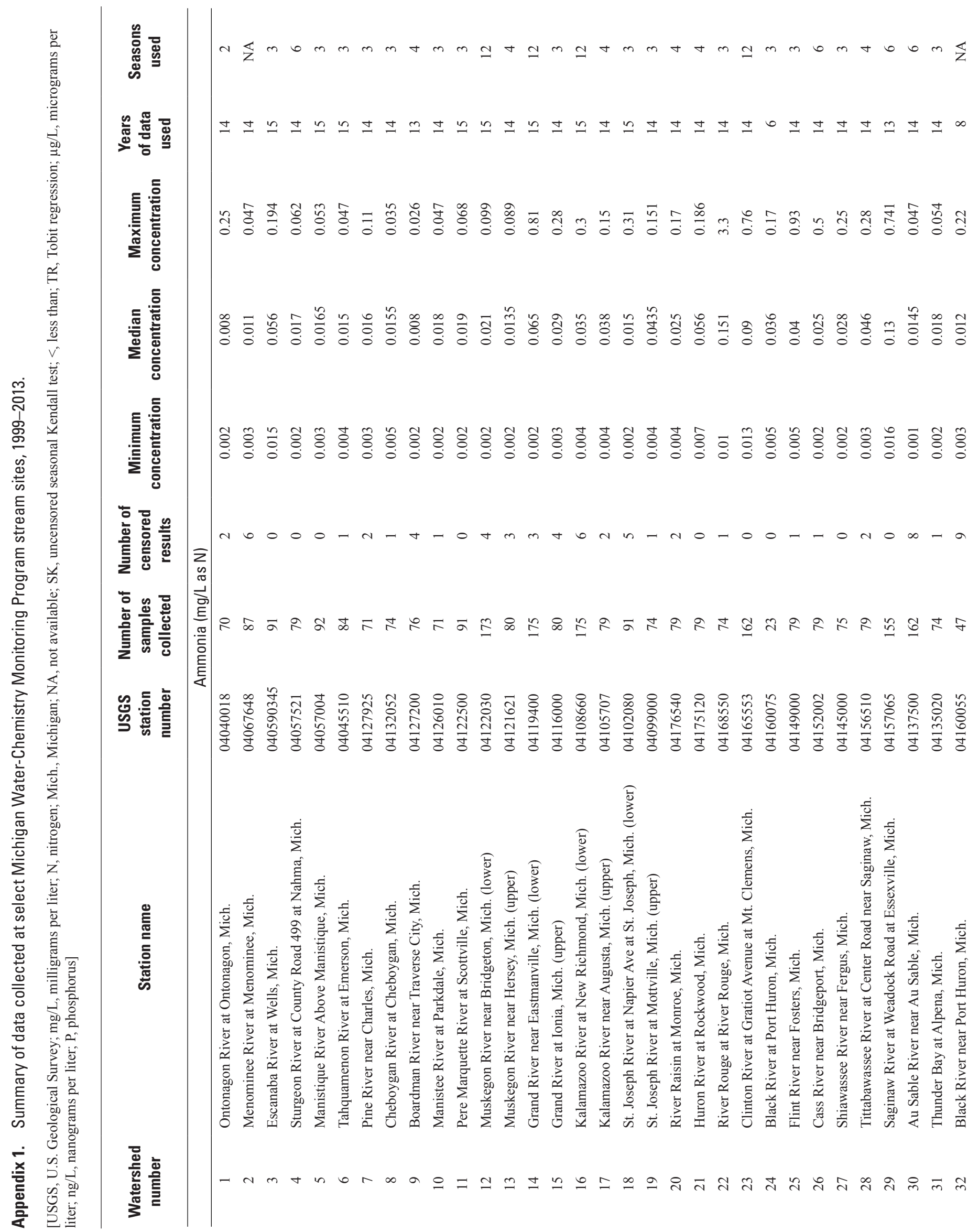




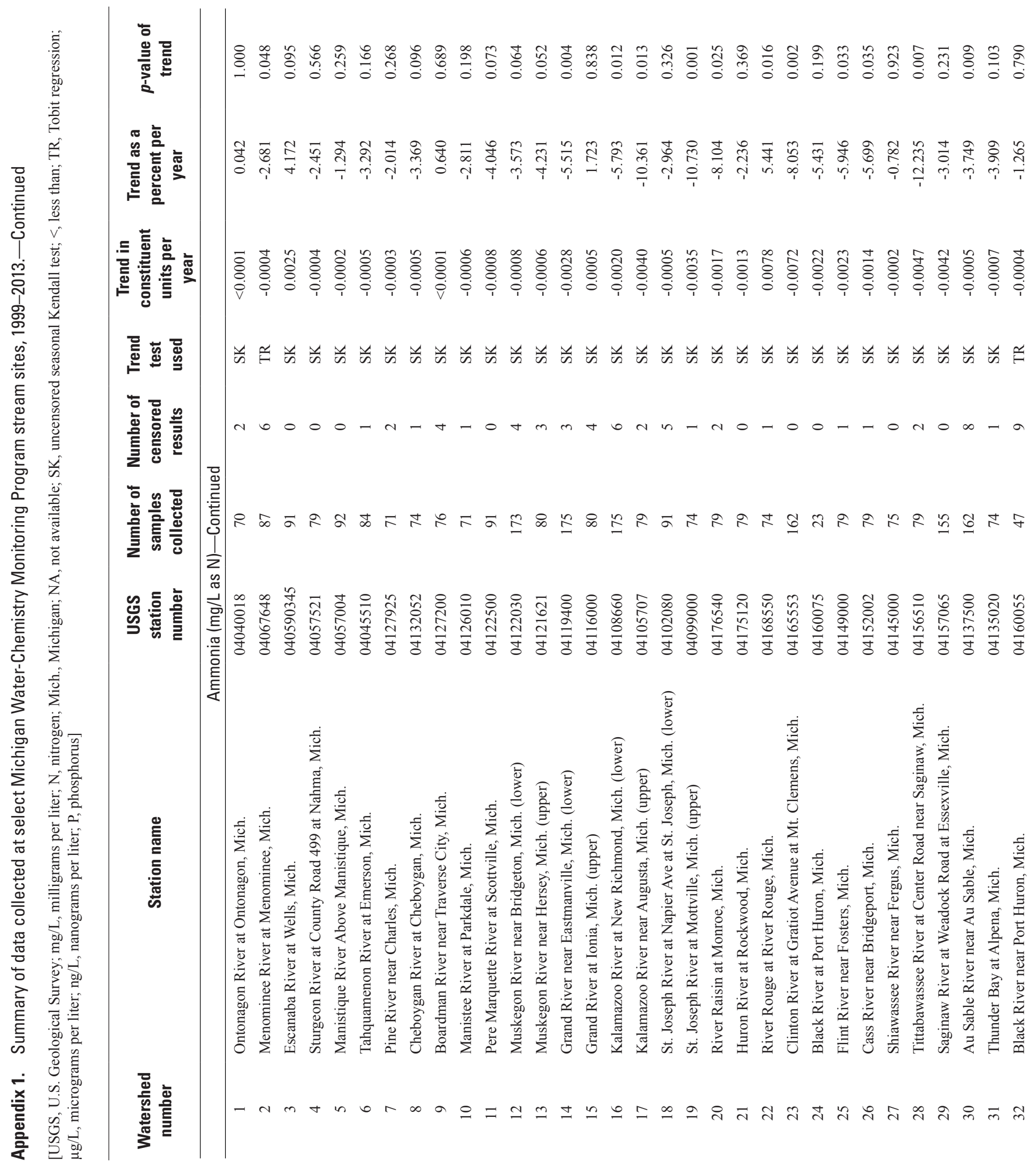




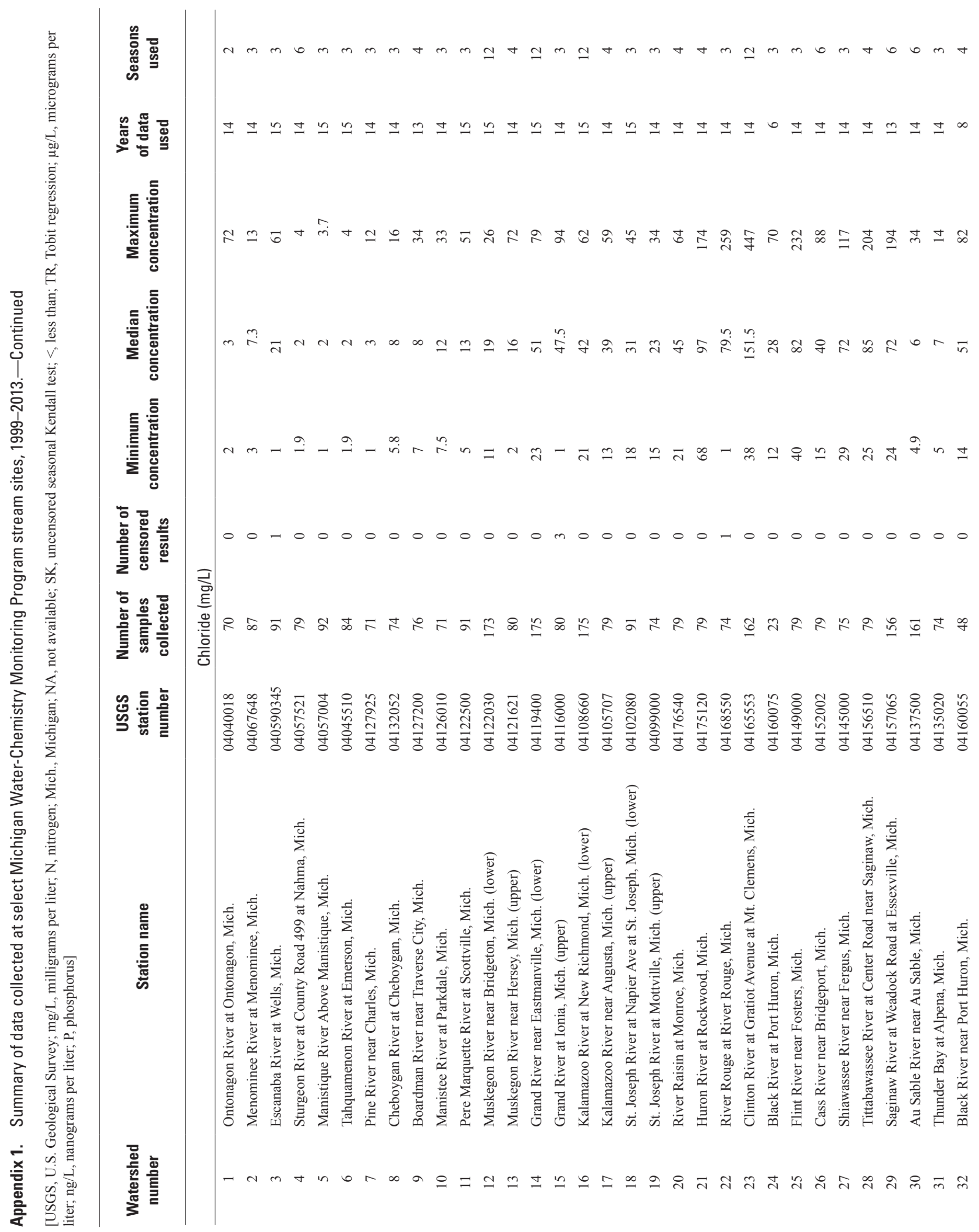




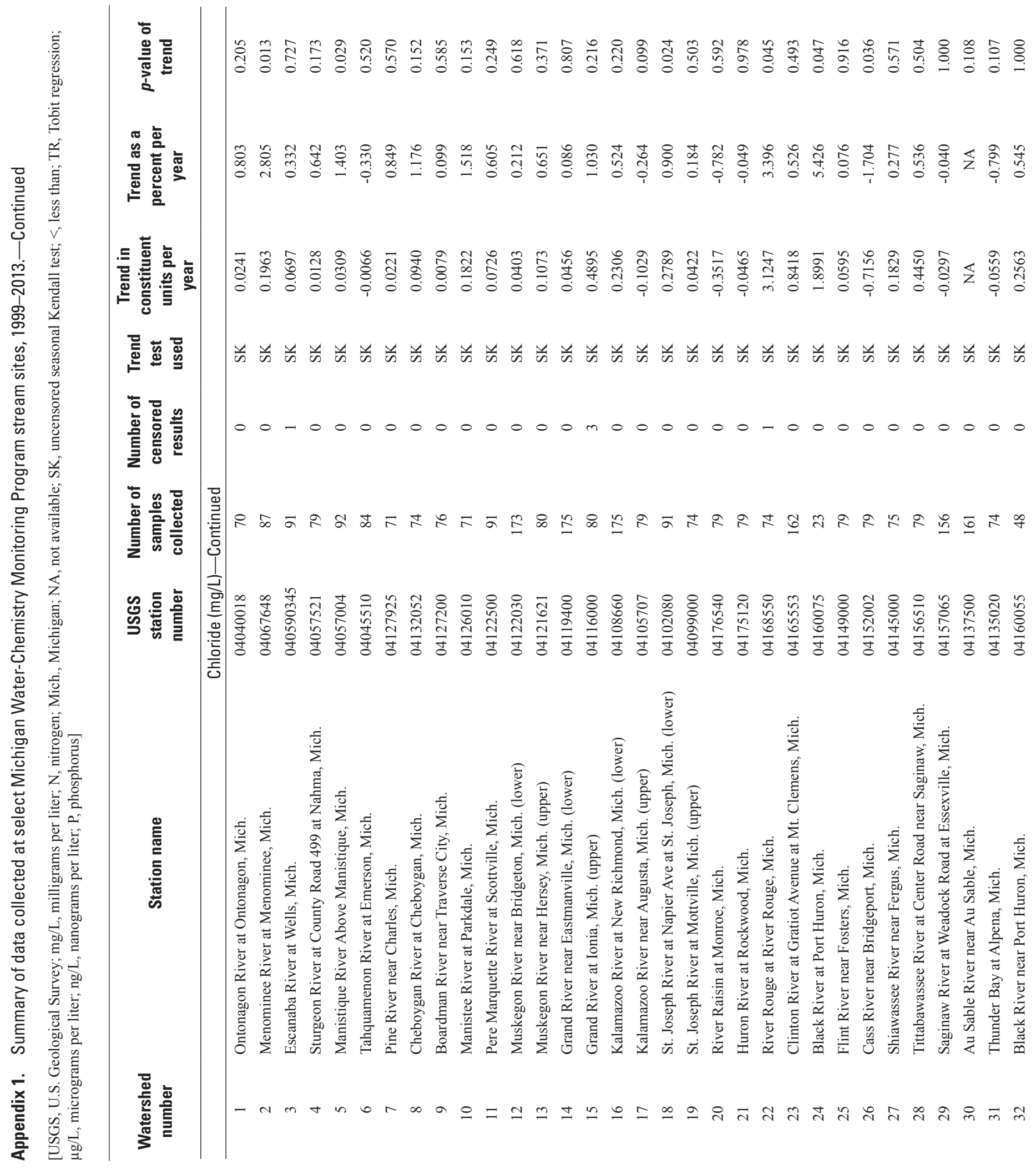




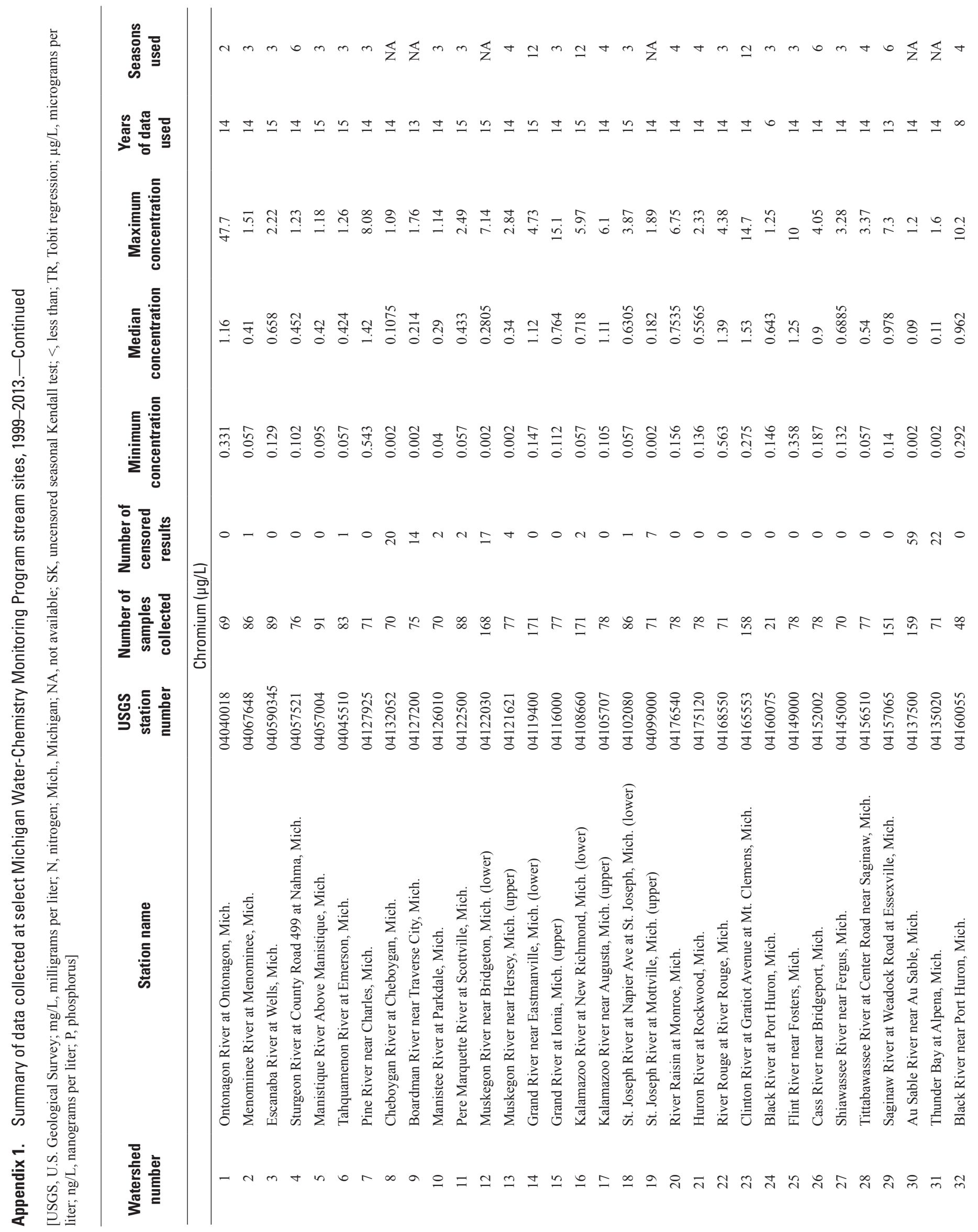




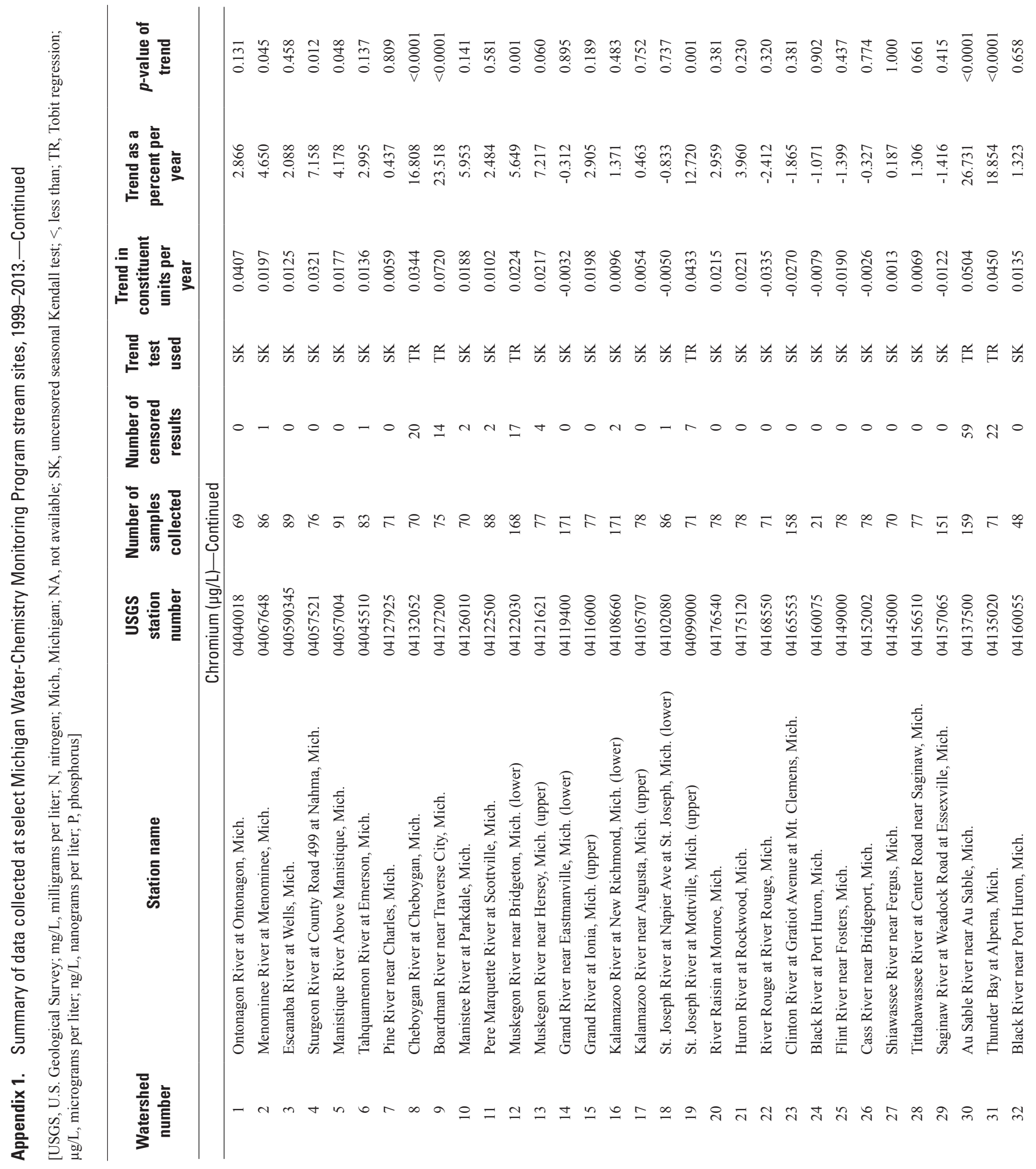




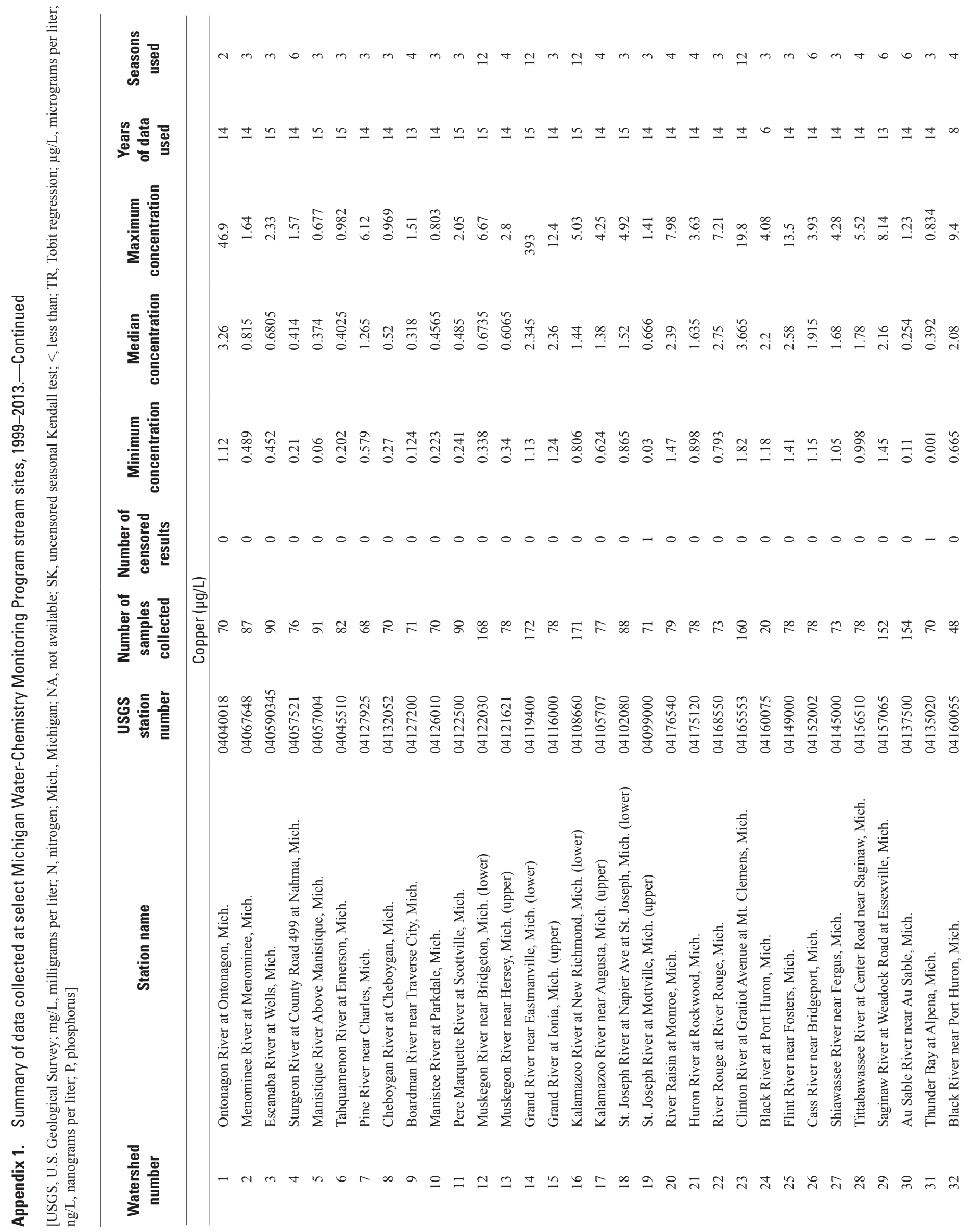




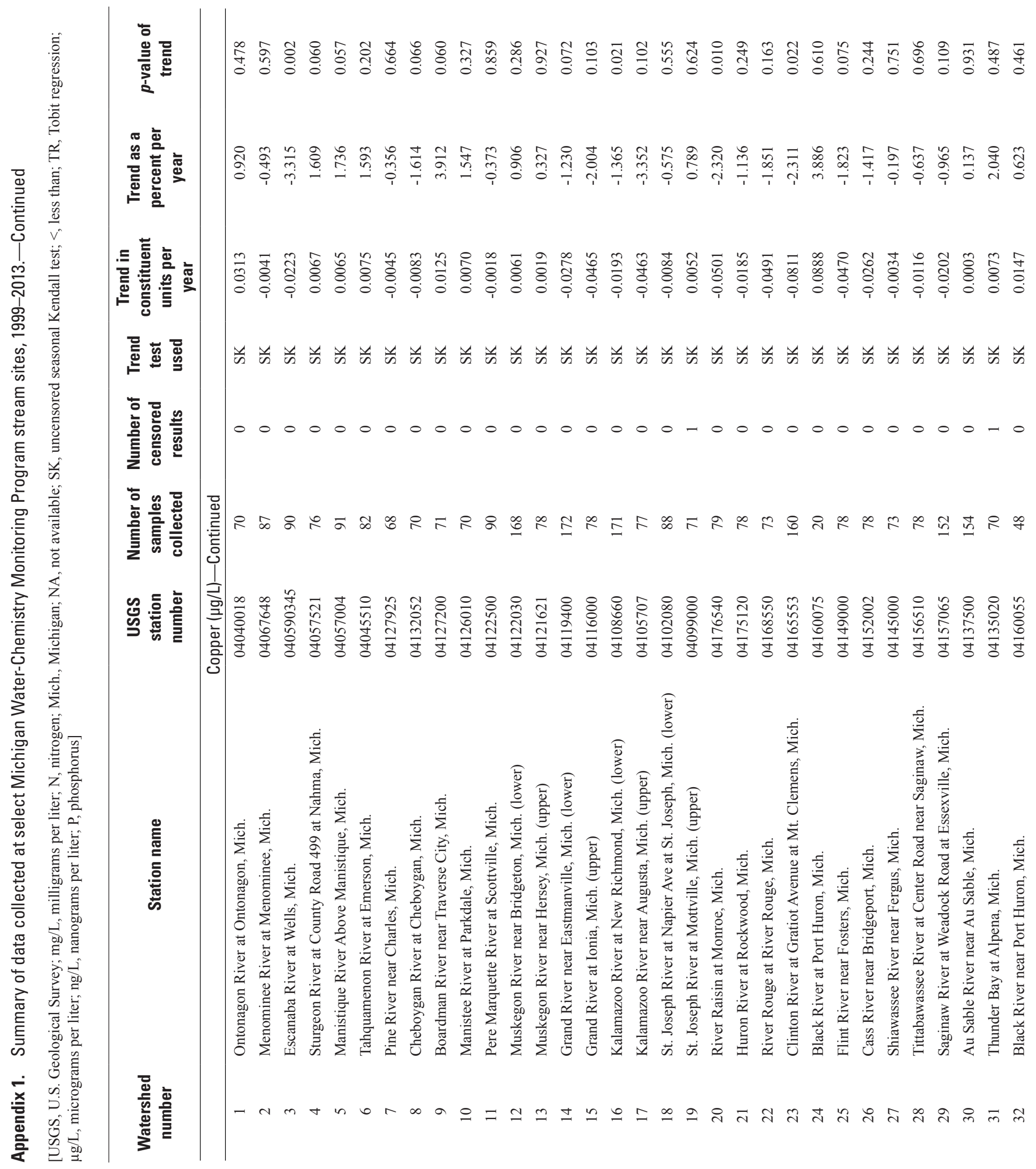




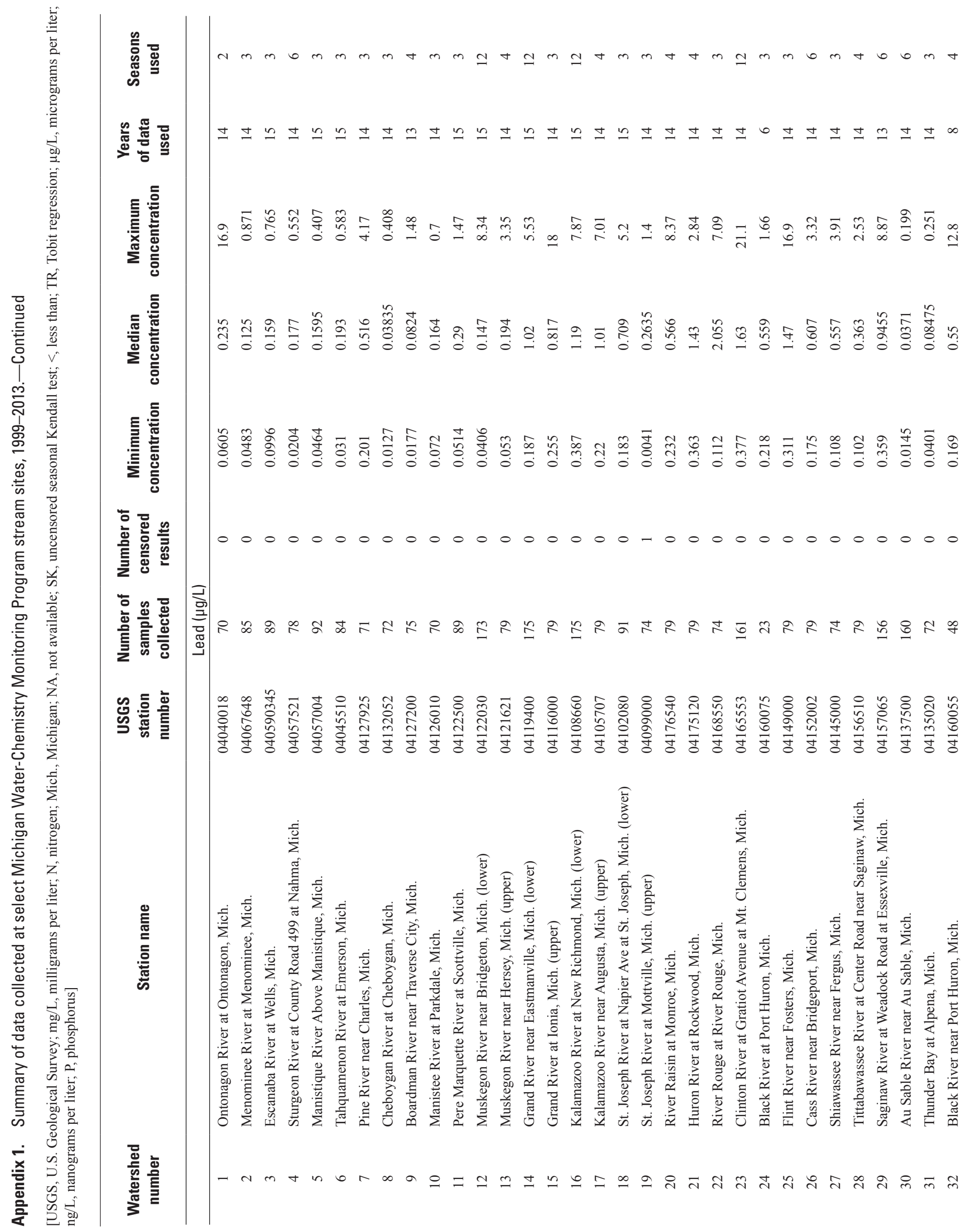




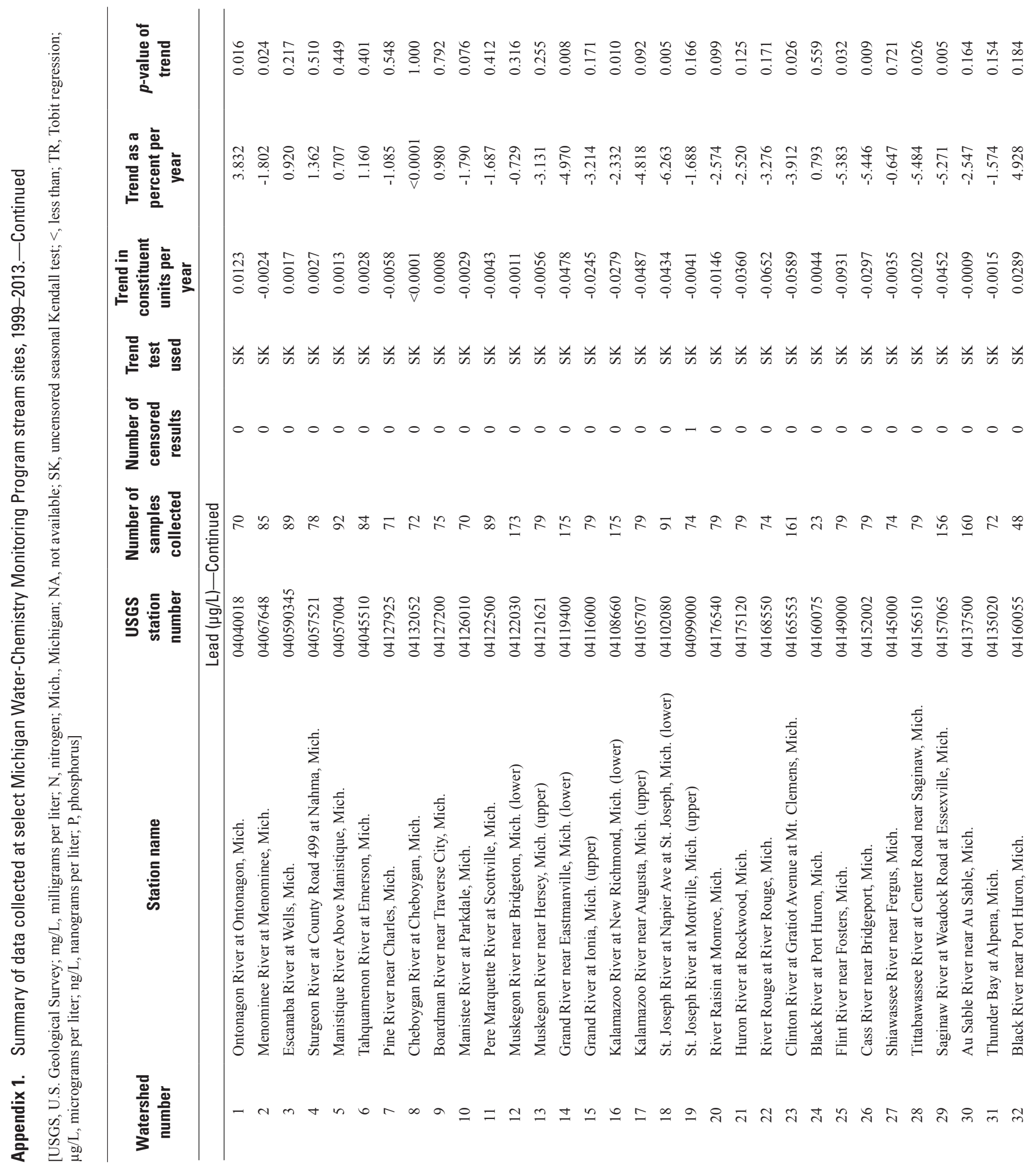




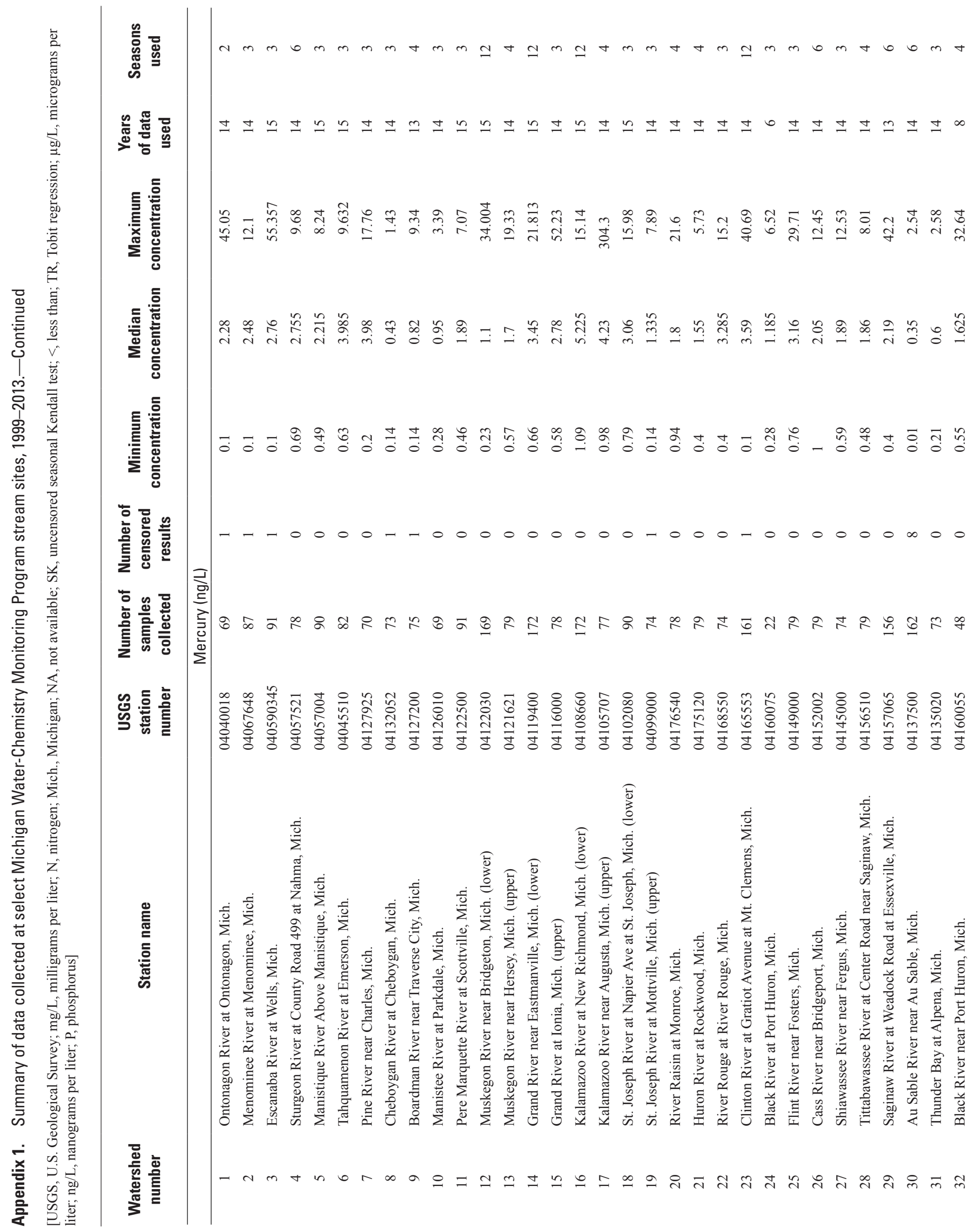




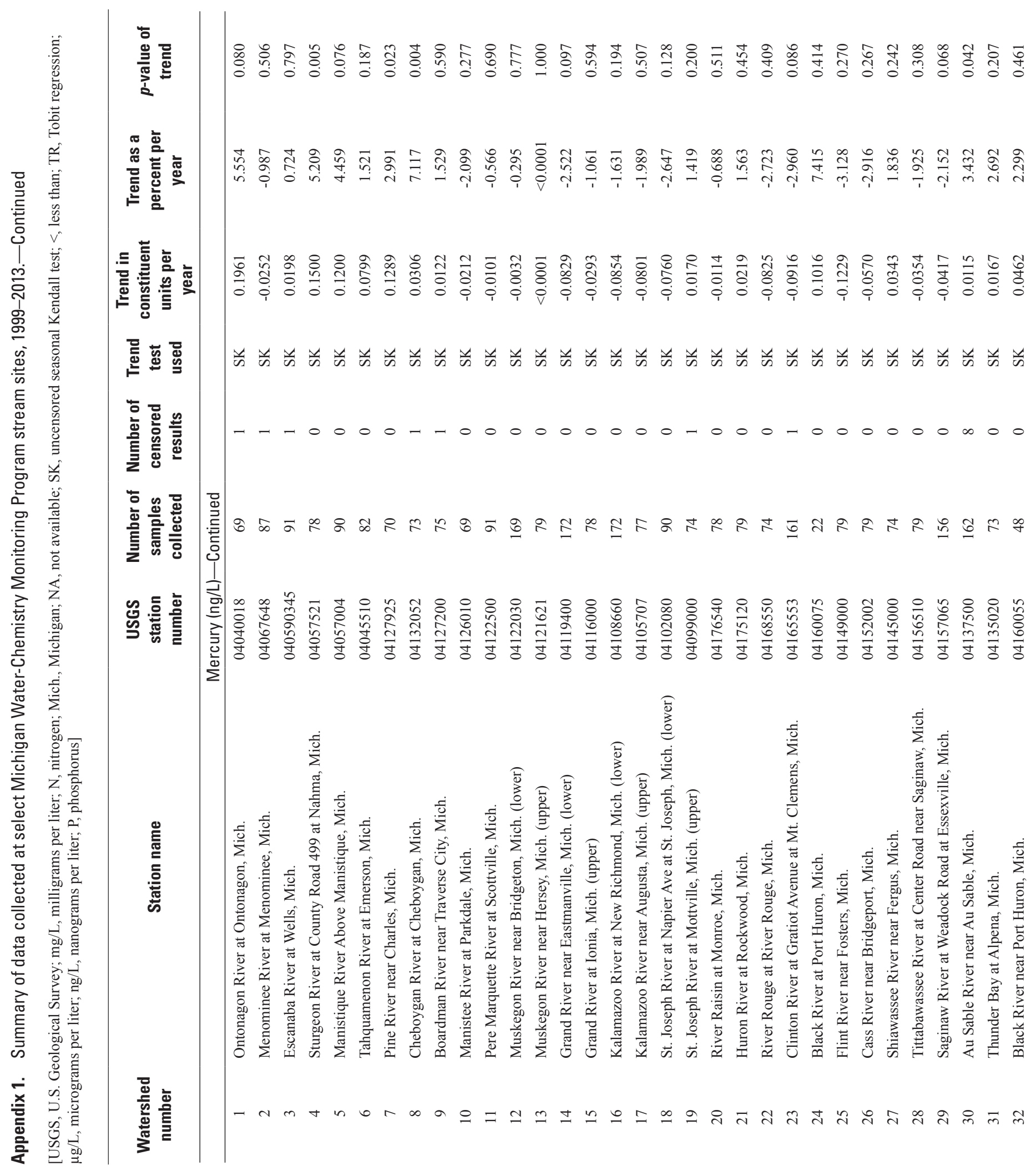




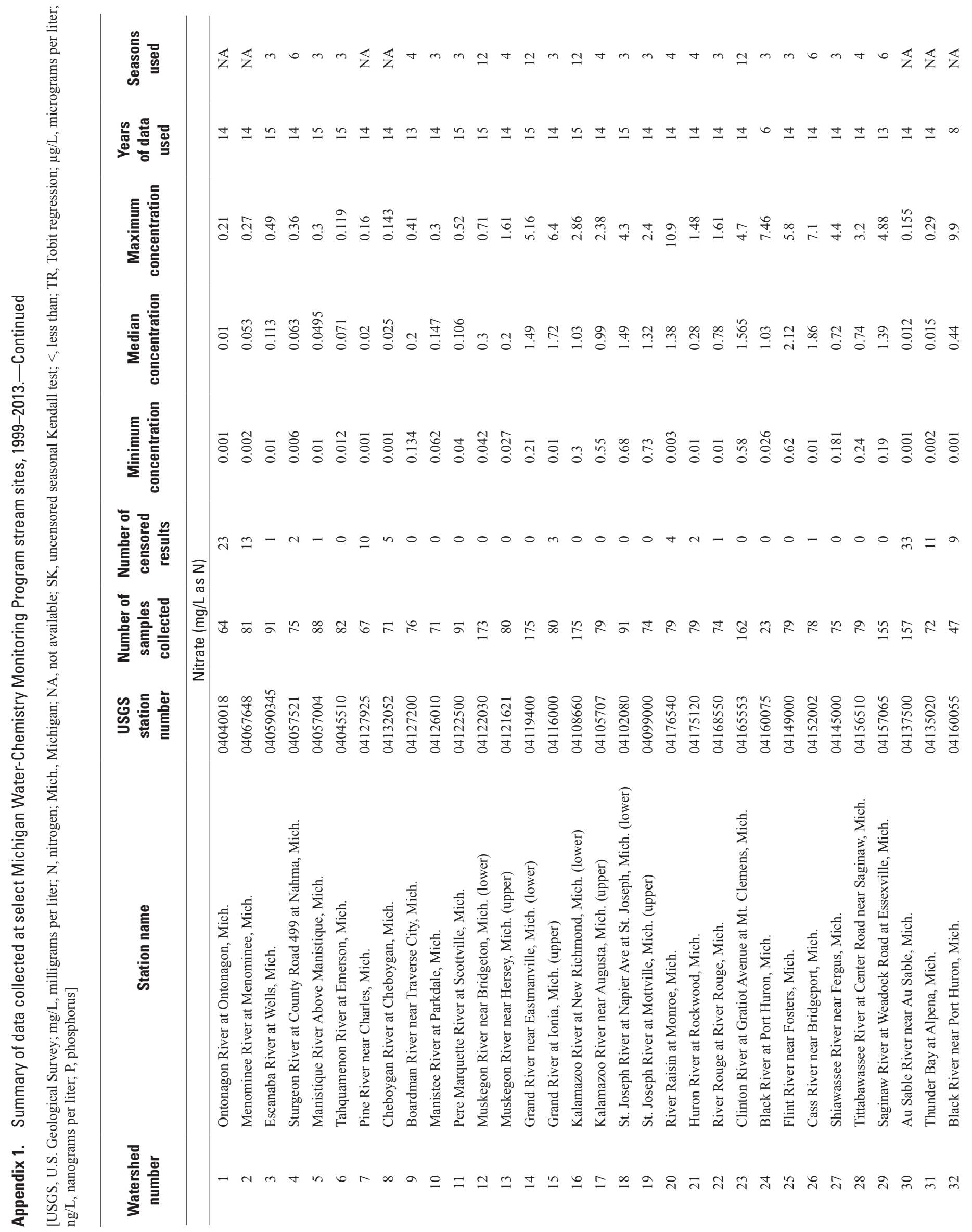




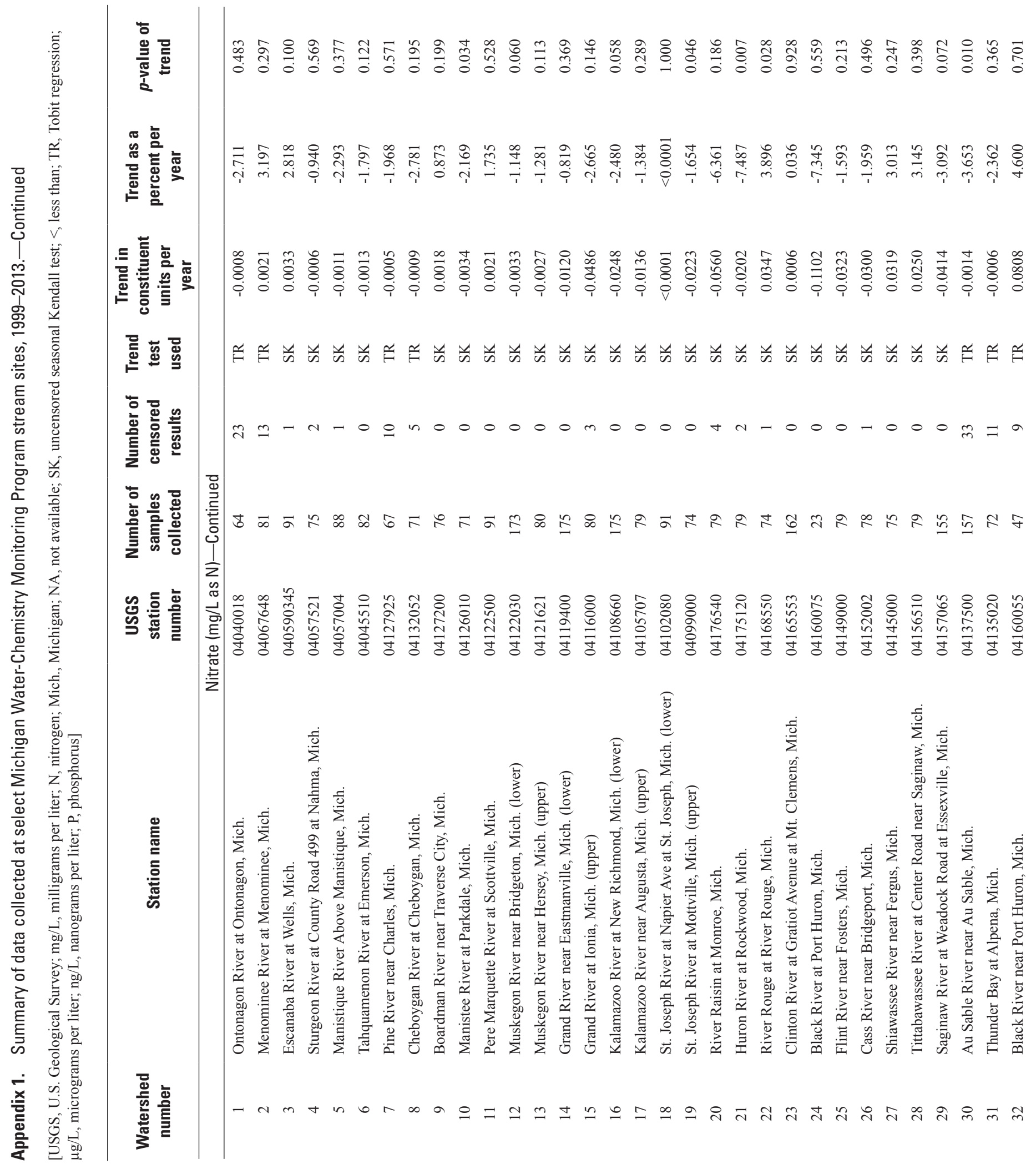




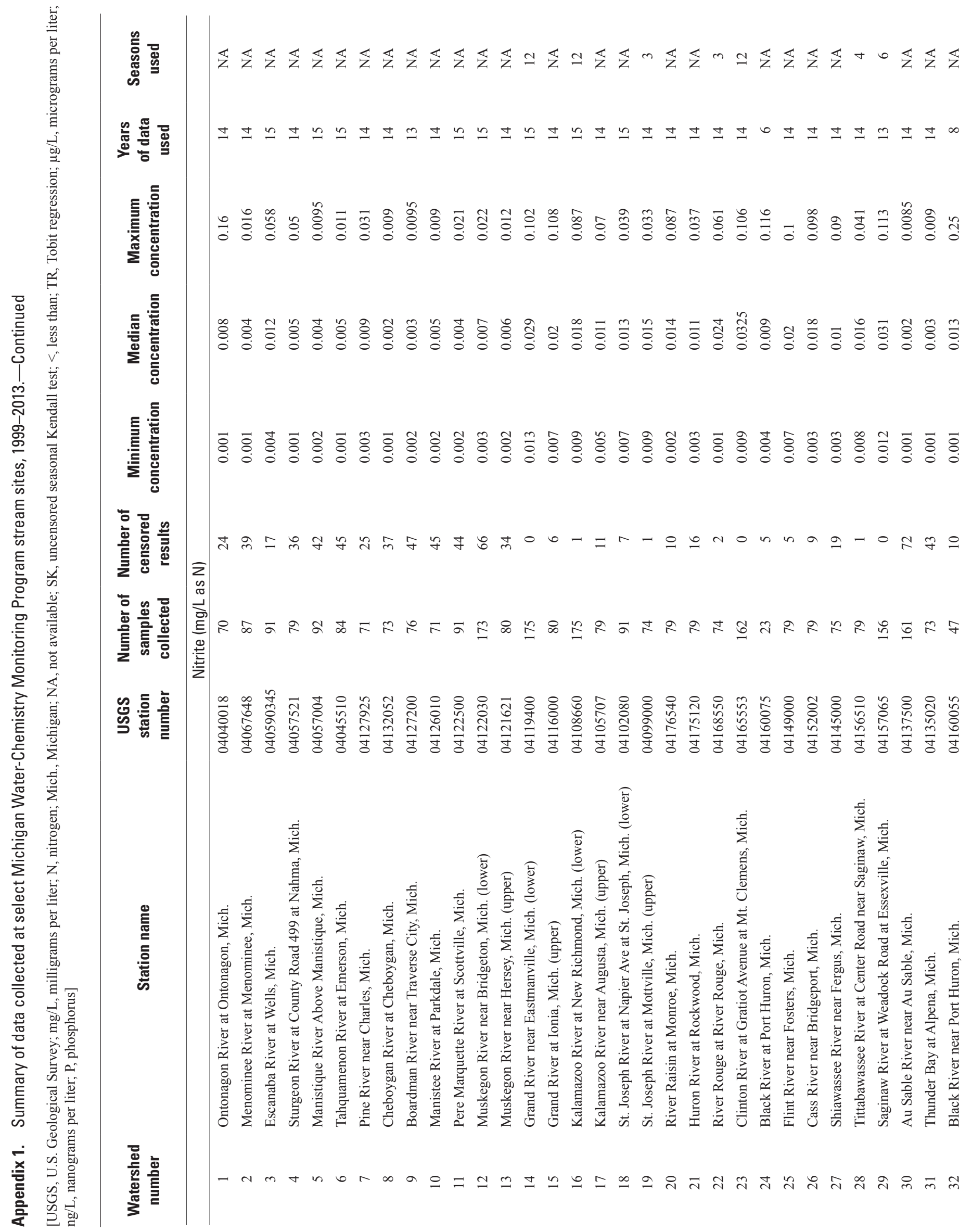




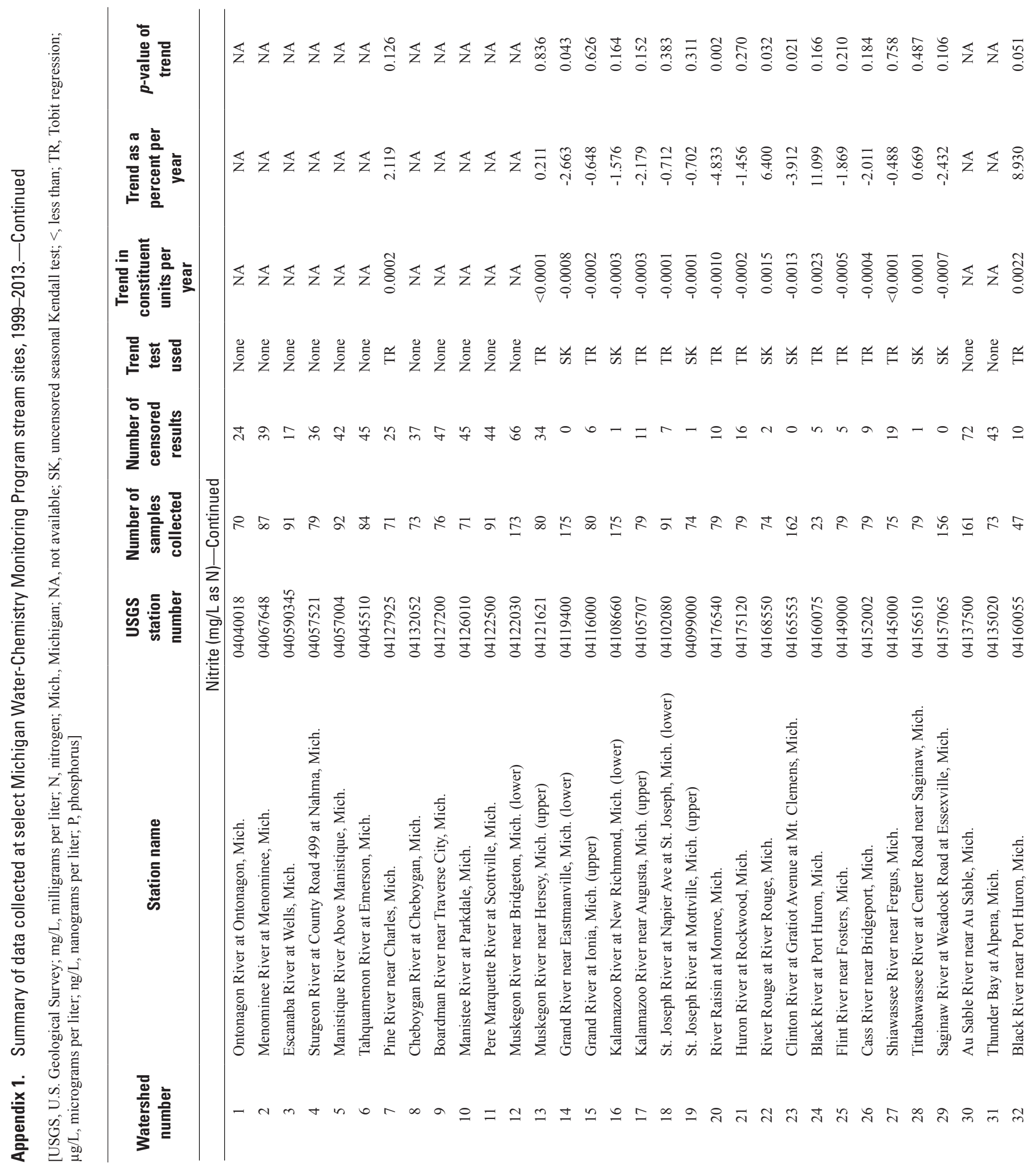




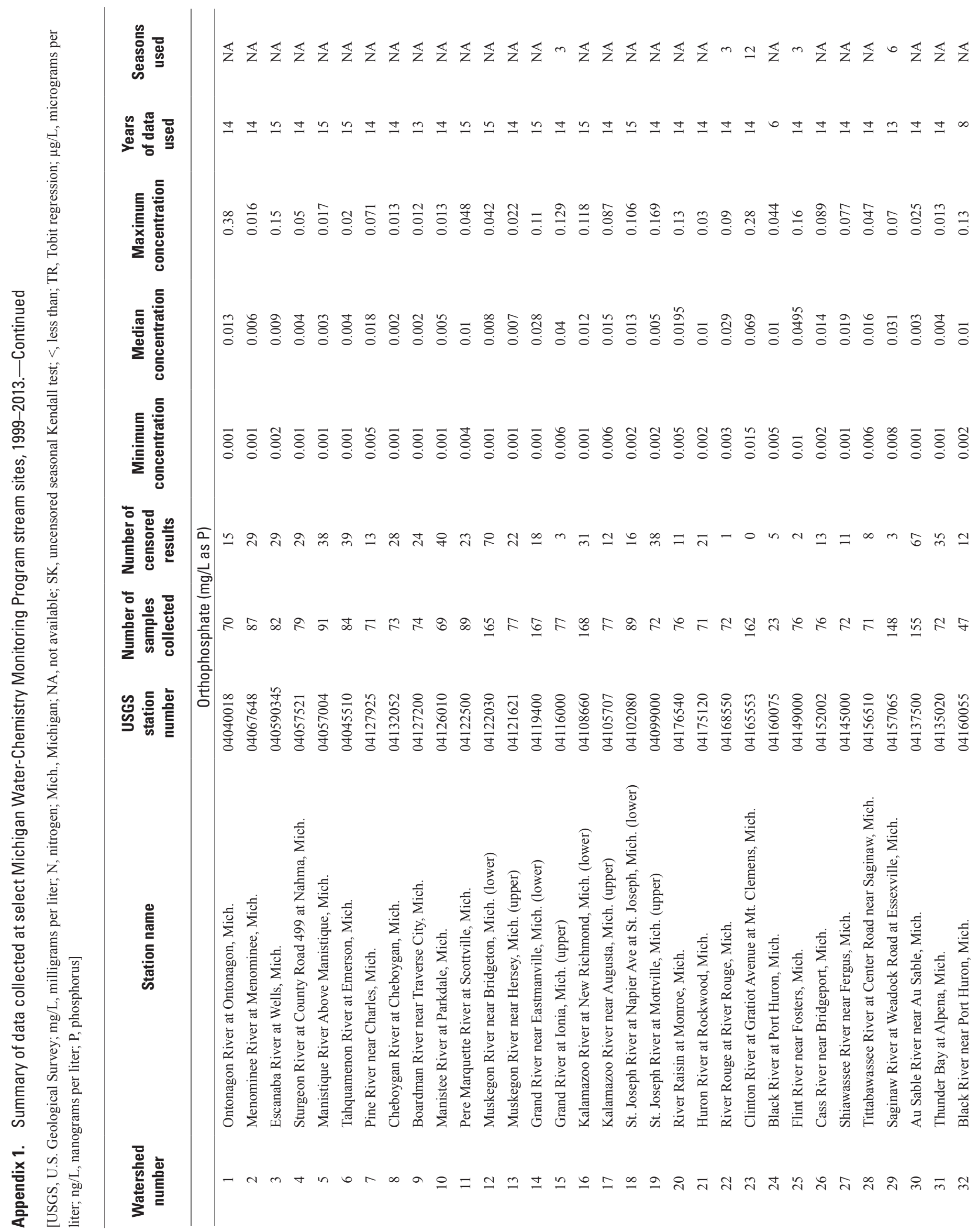




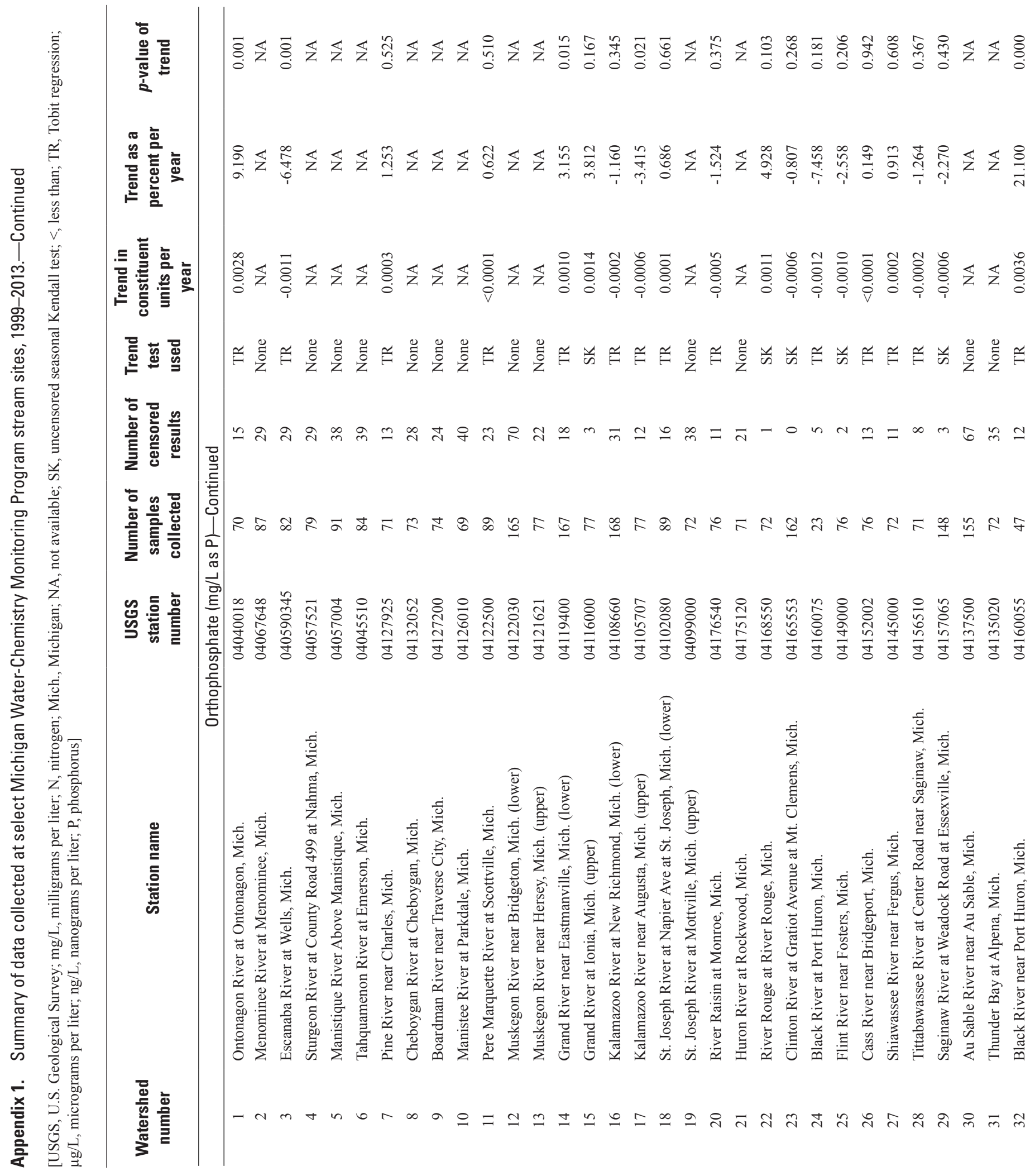




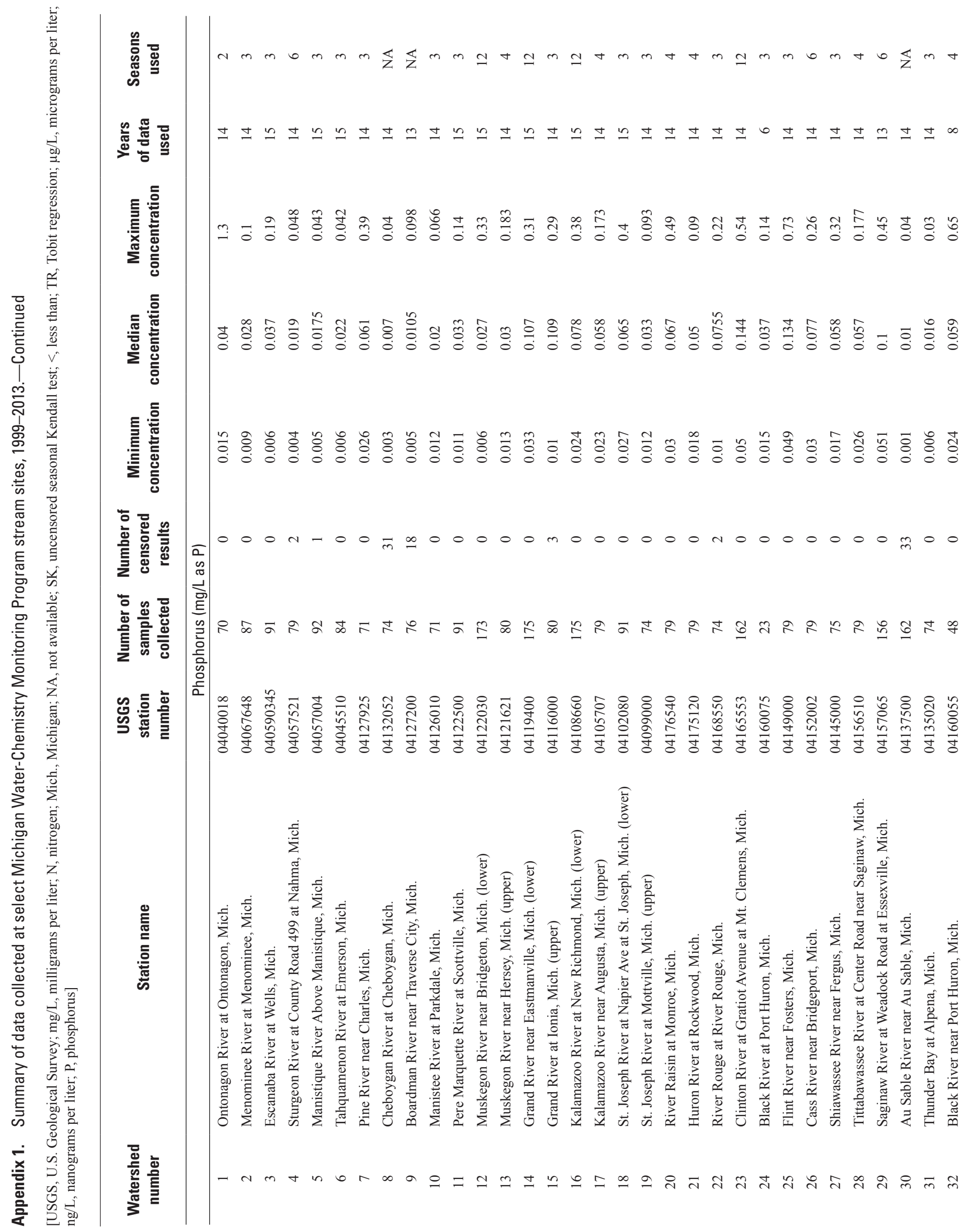




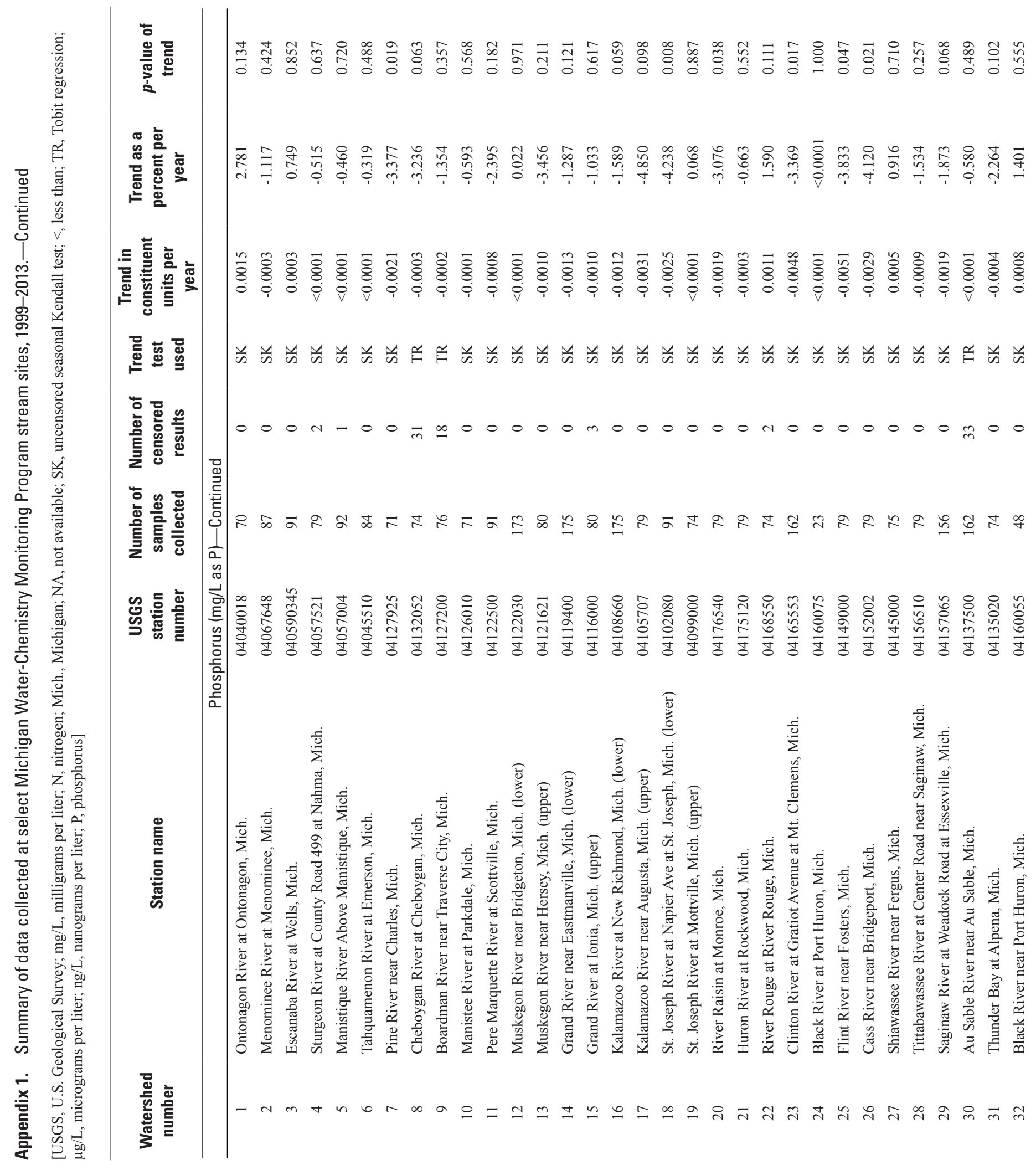




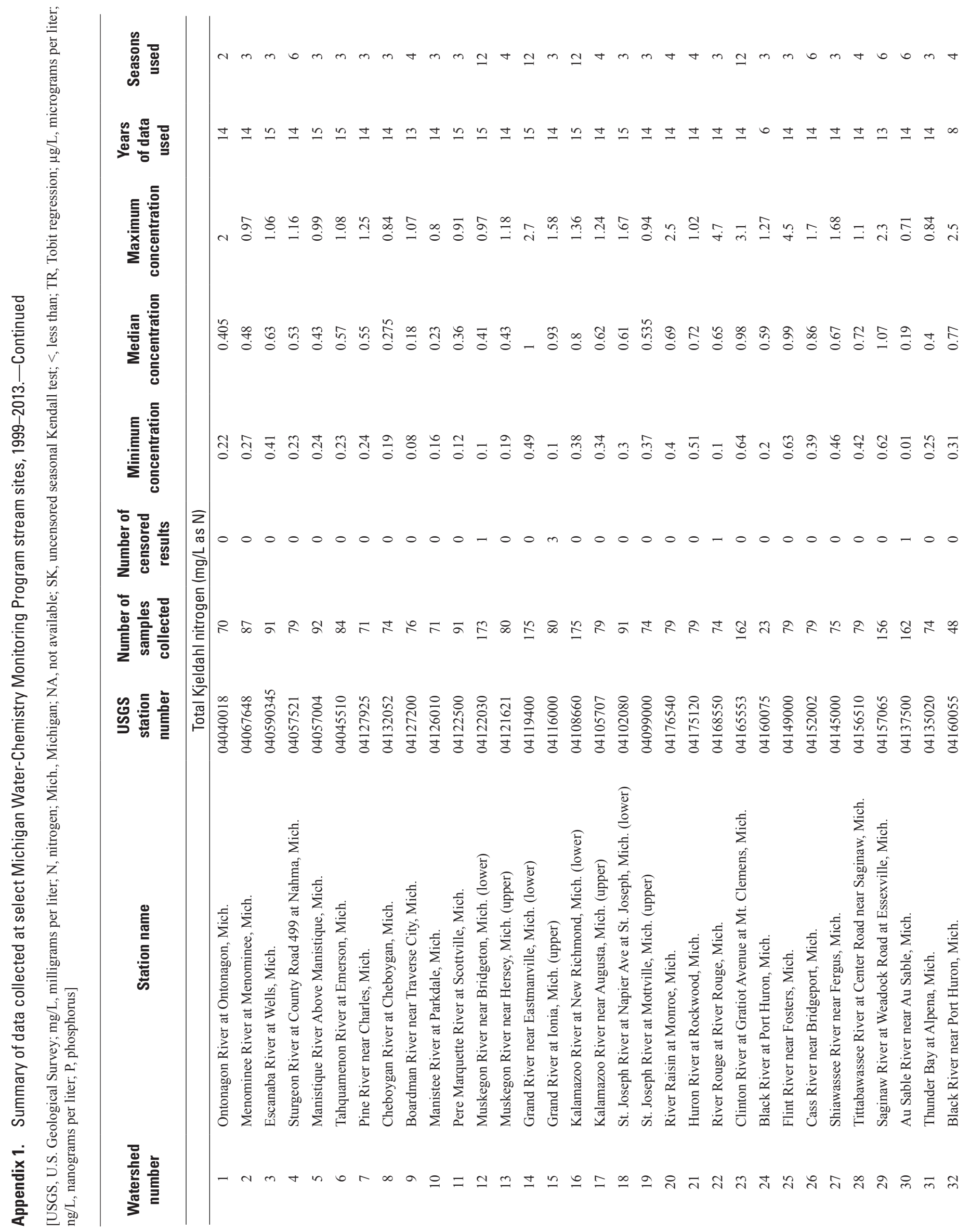




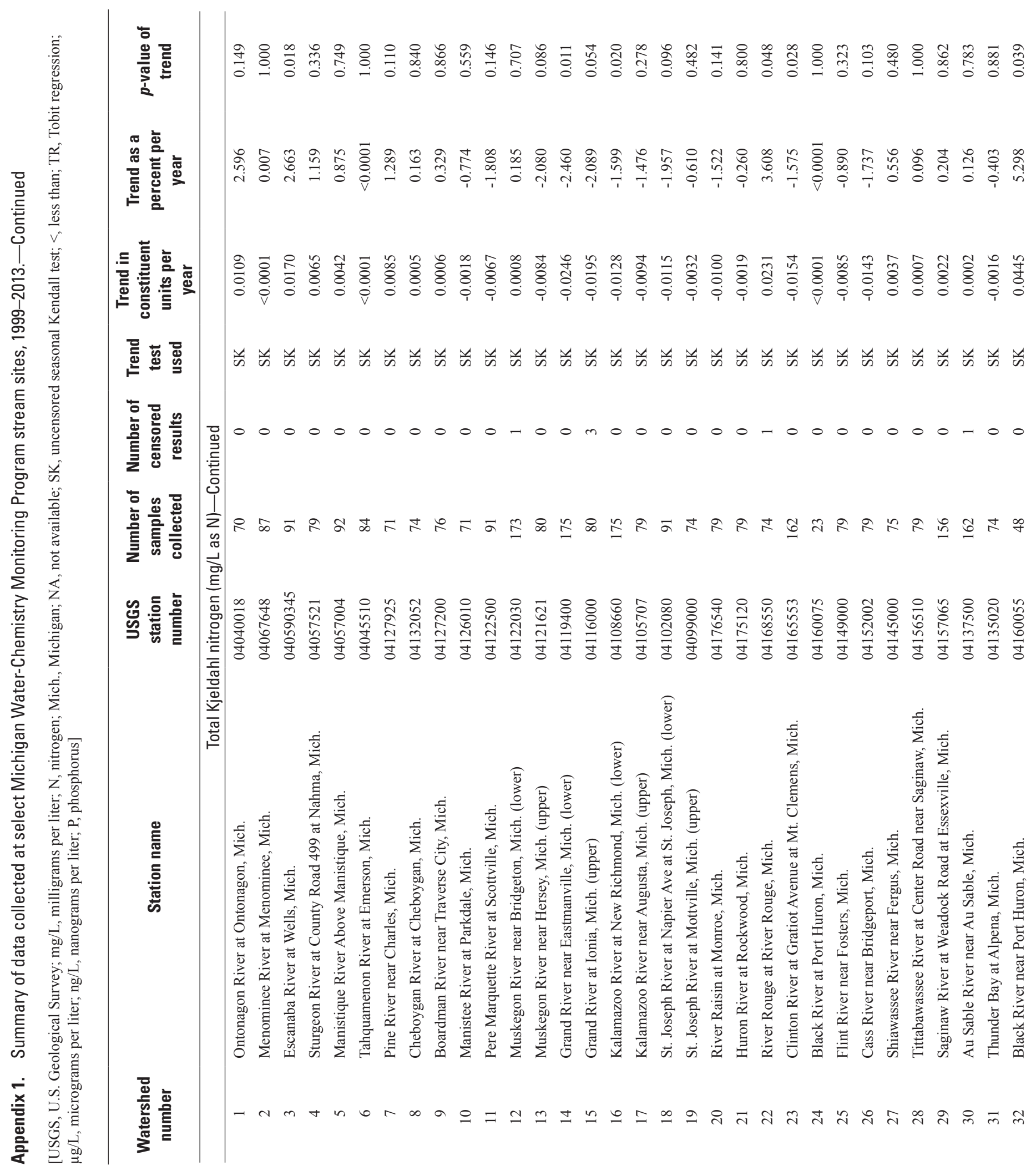




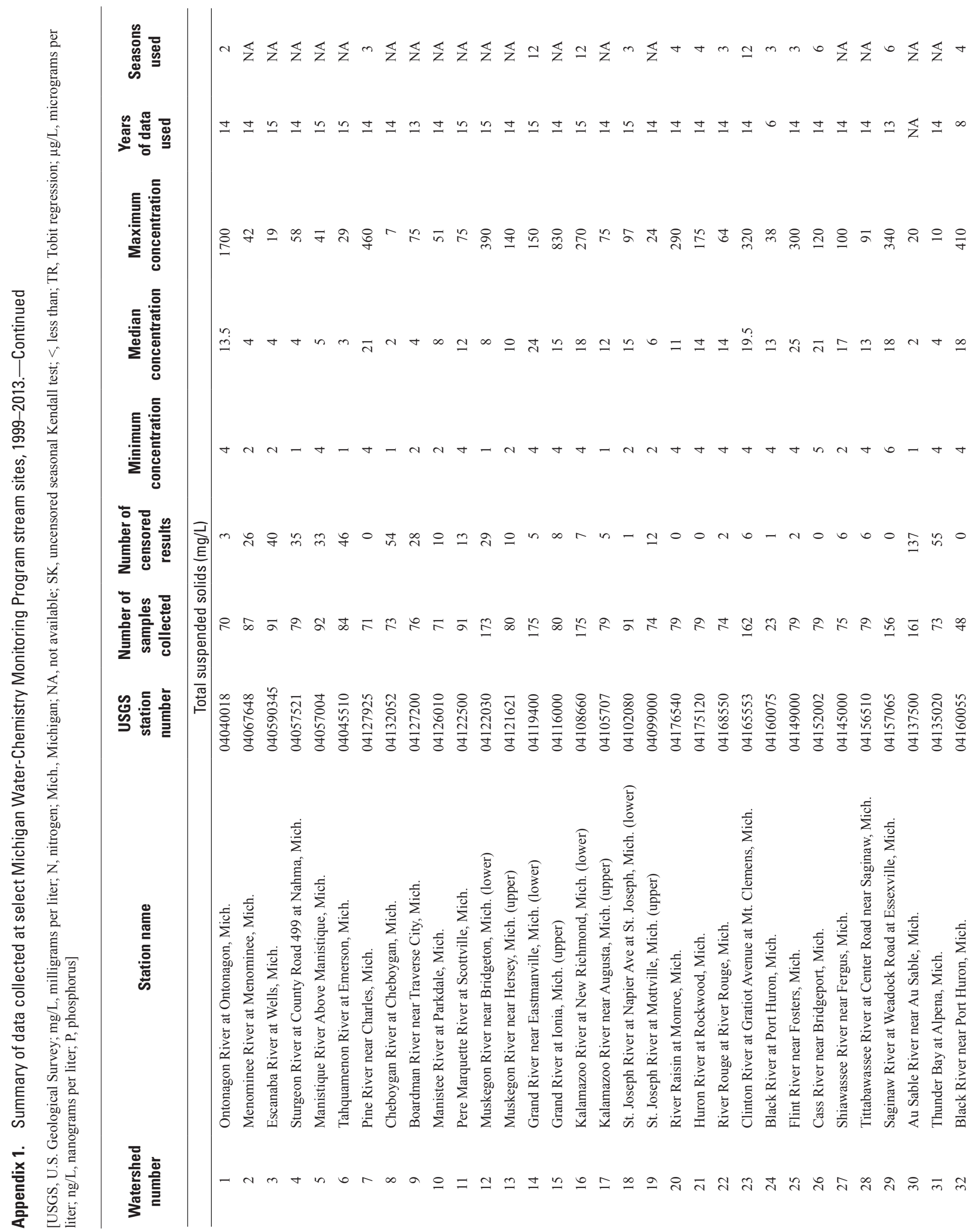




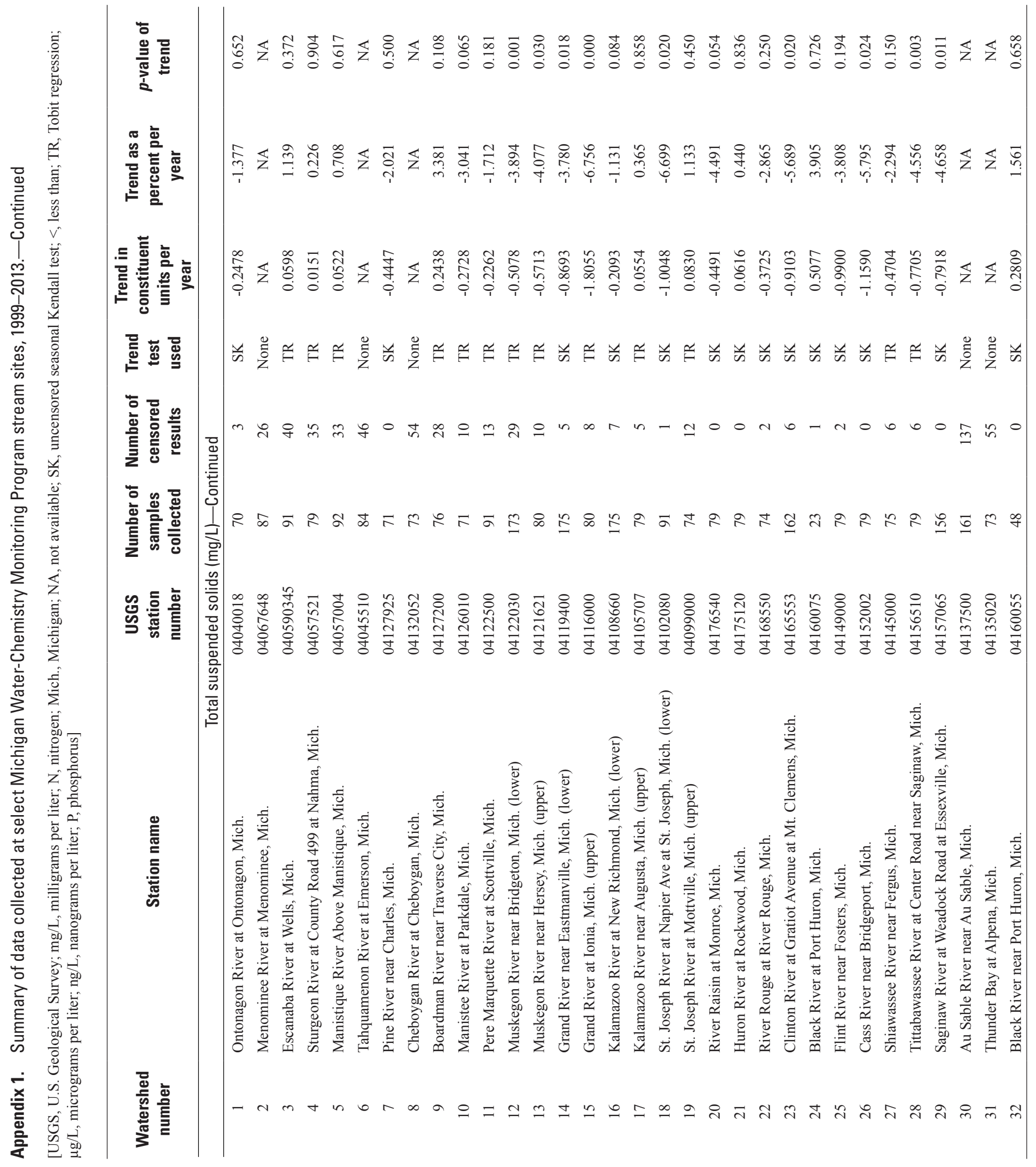




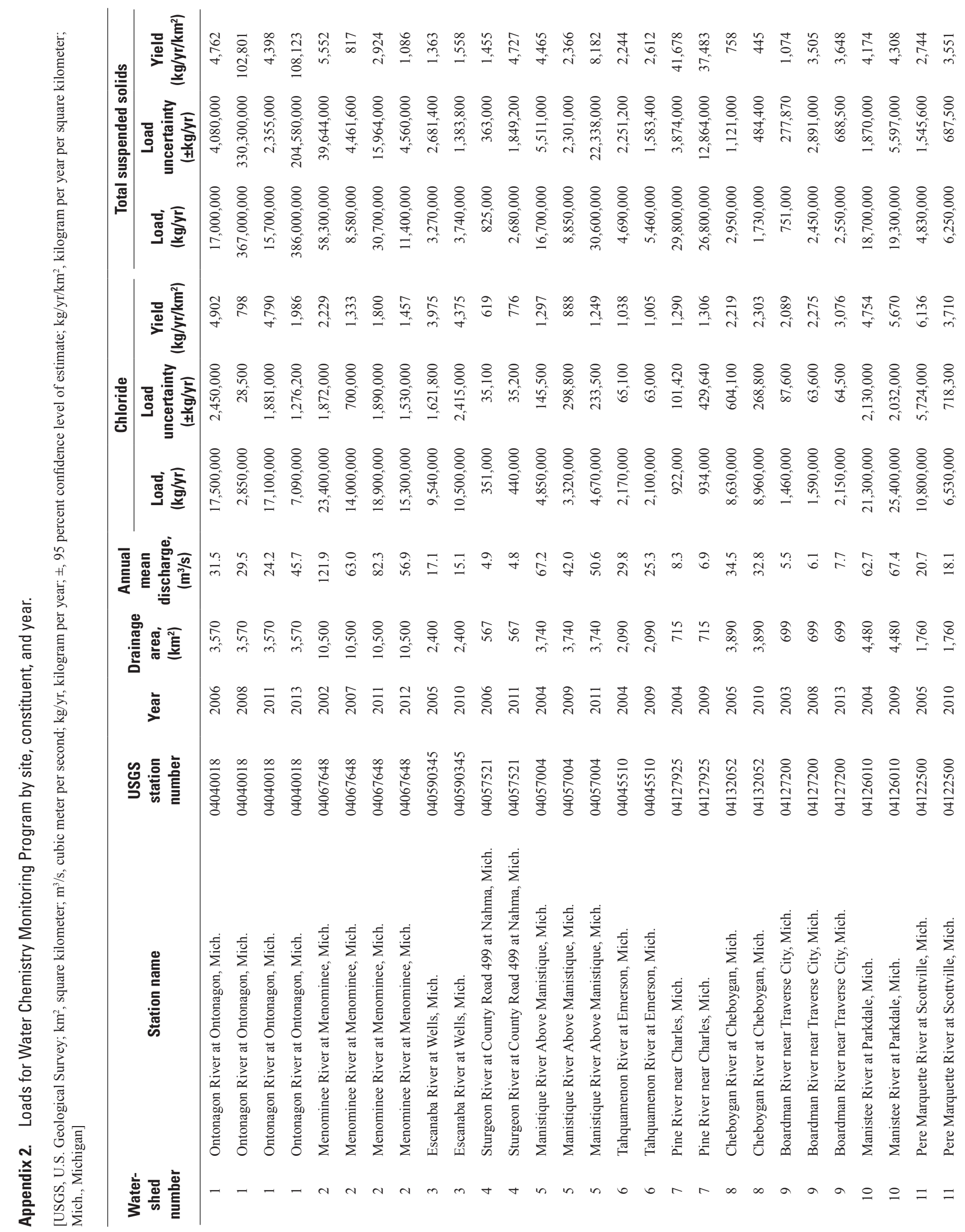




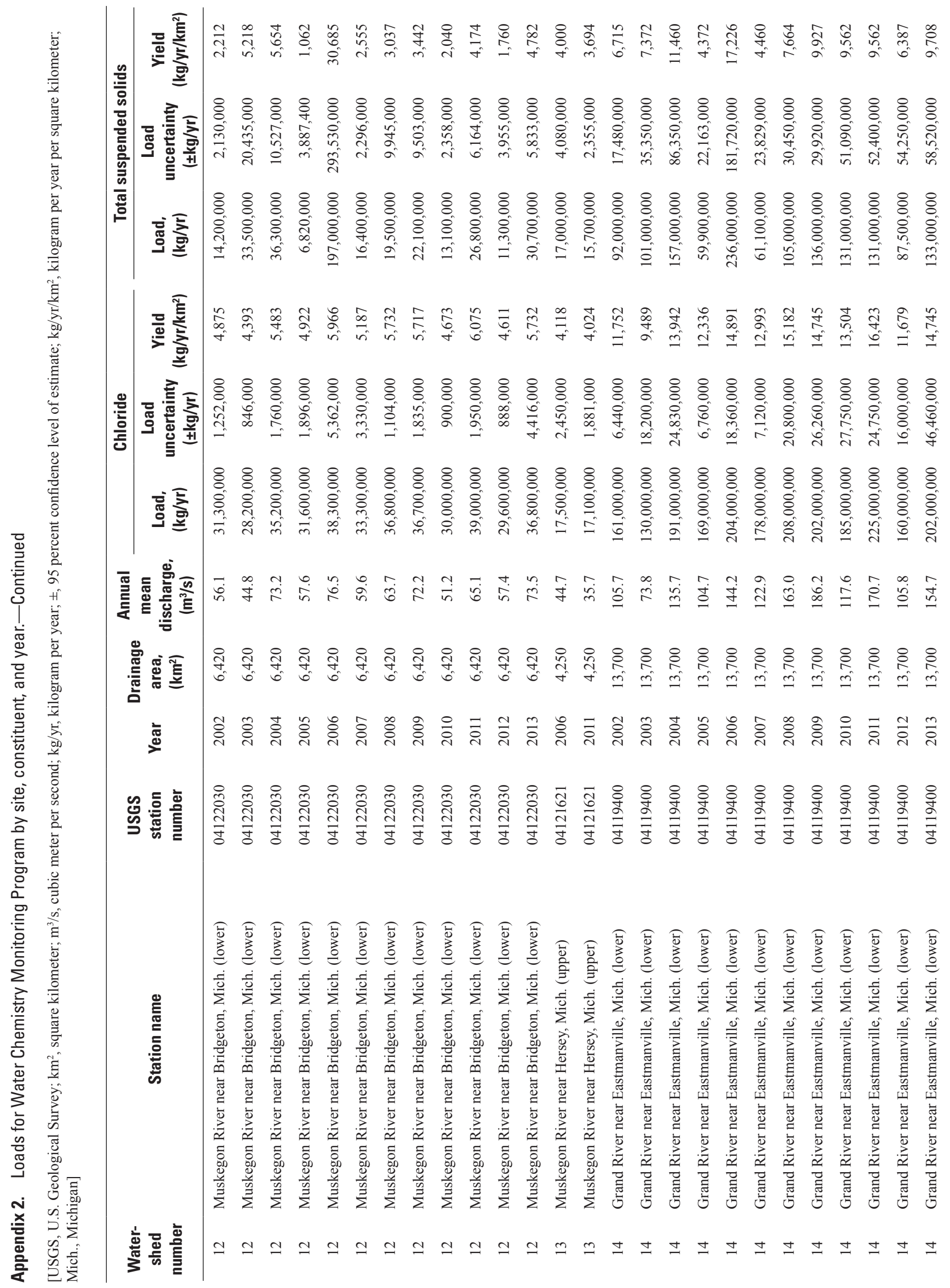




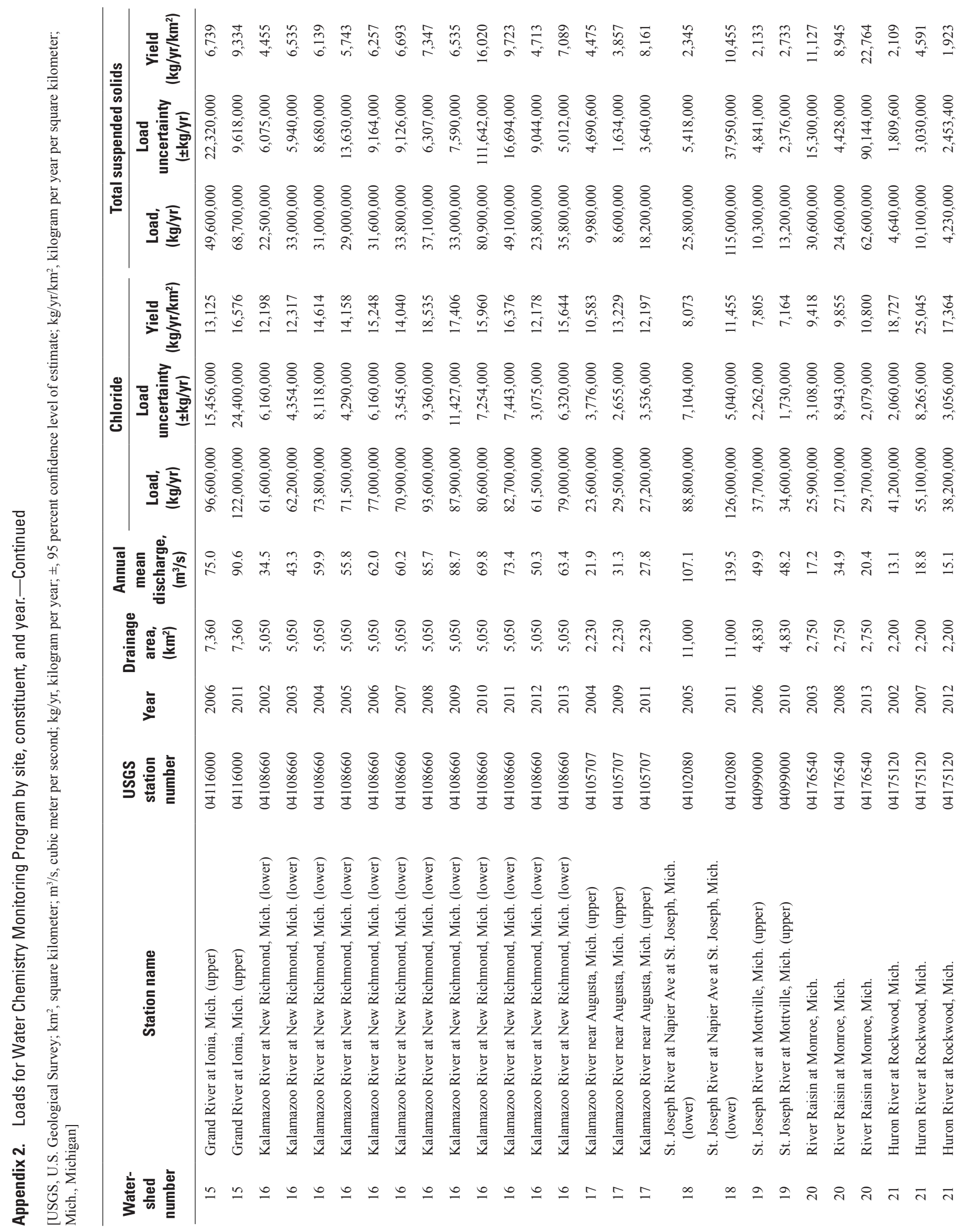




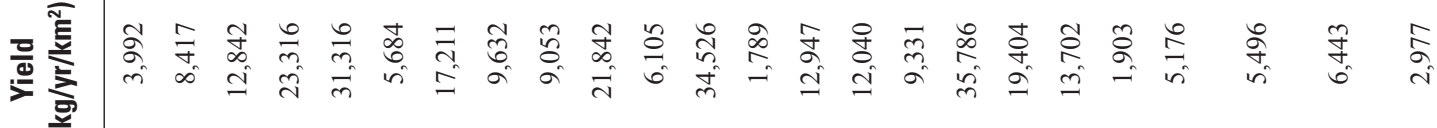

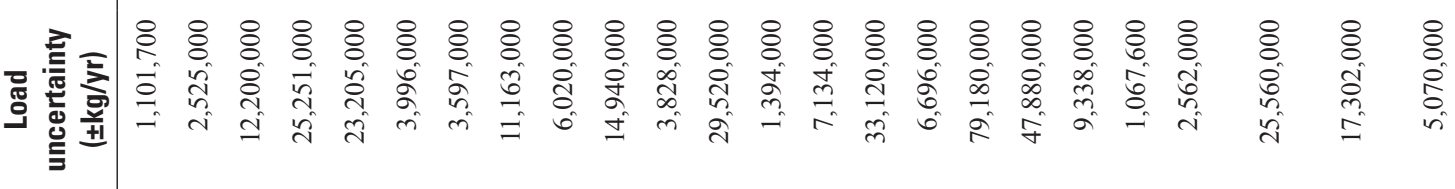

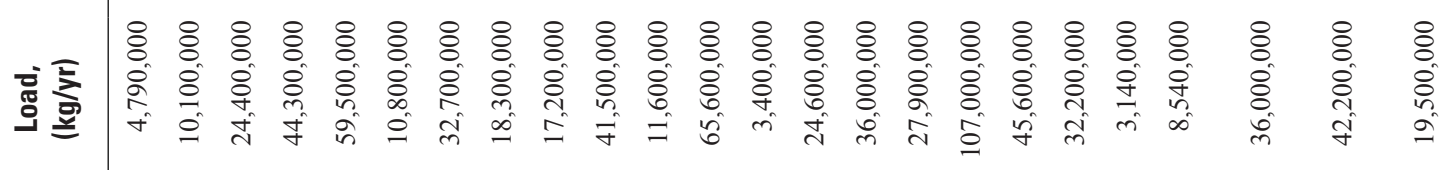

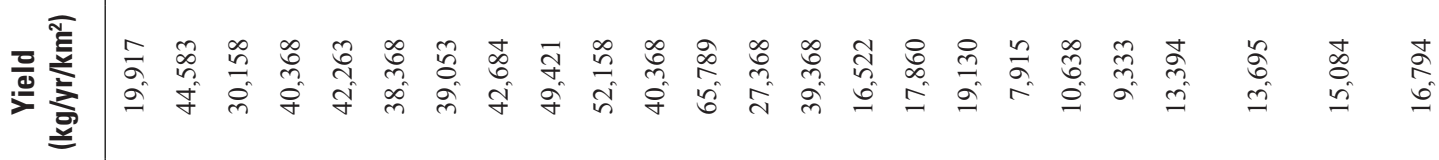

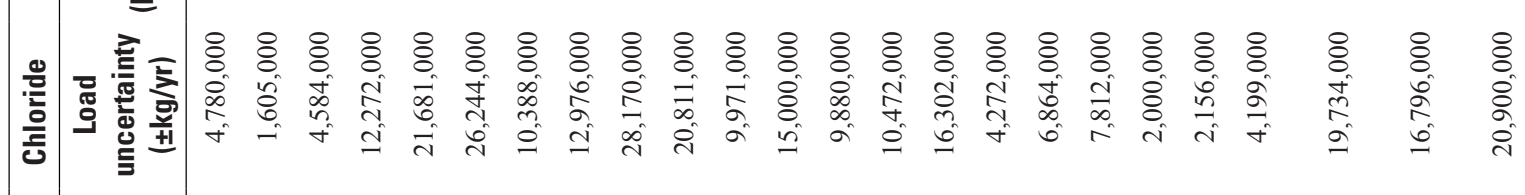

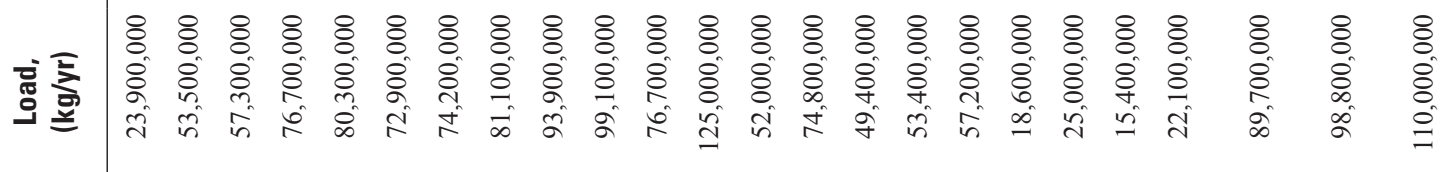

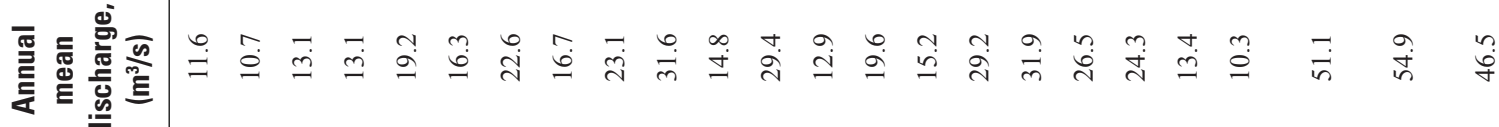

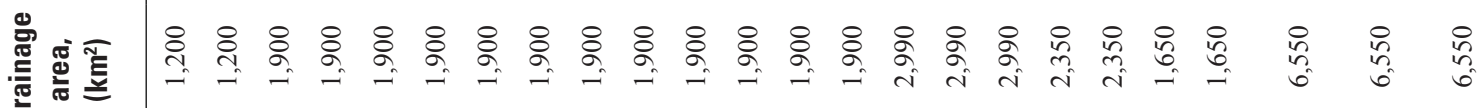

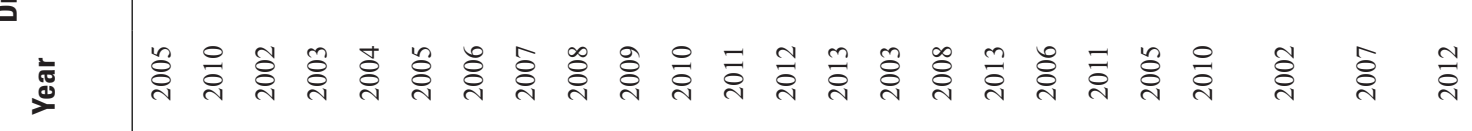

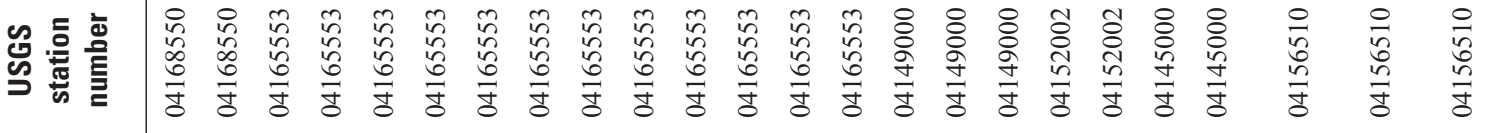

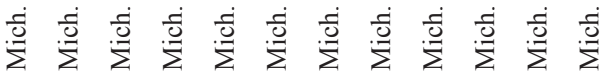

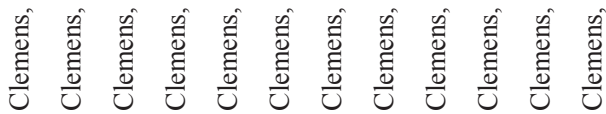

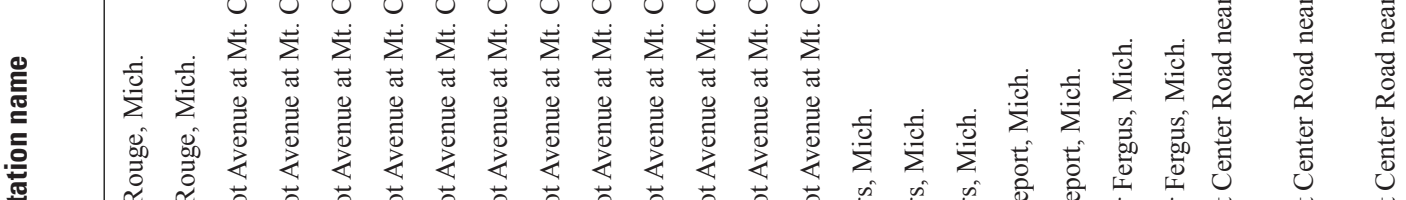

蛋

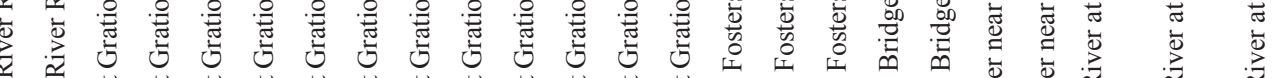

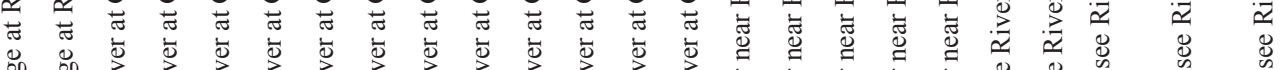

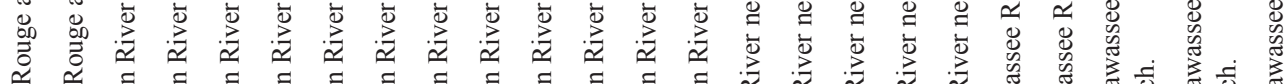

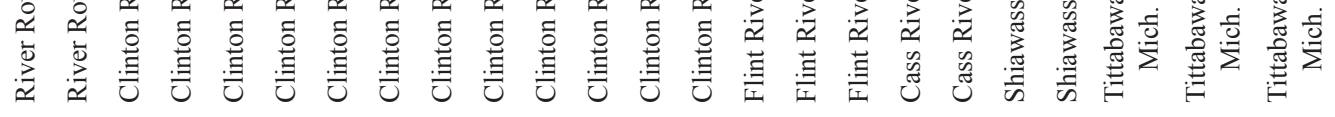

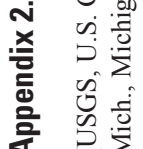




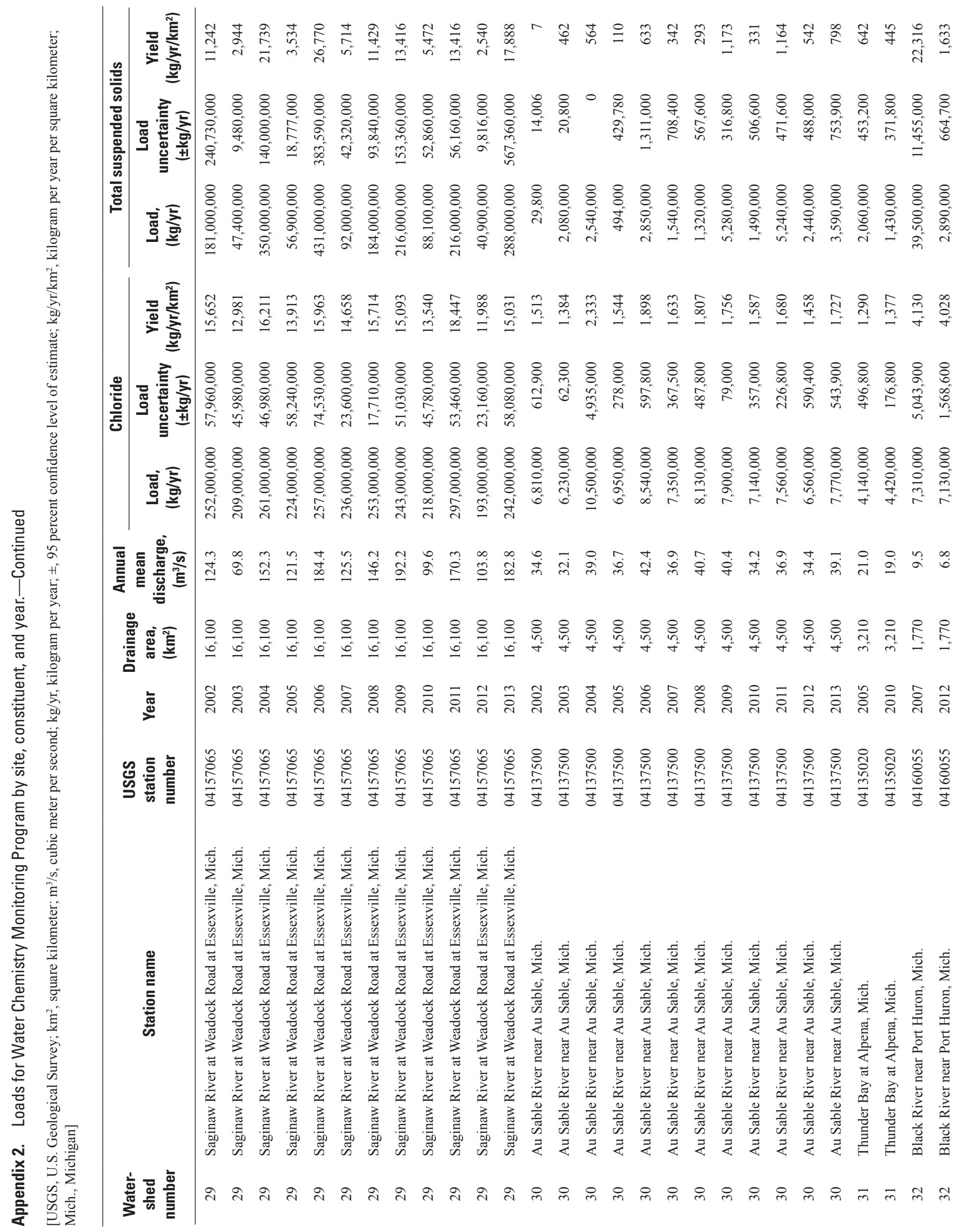




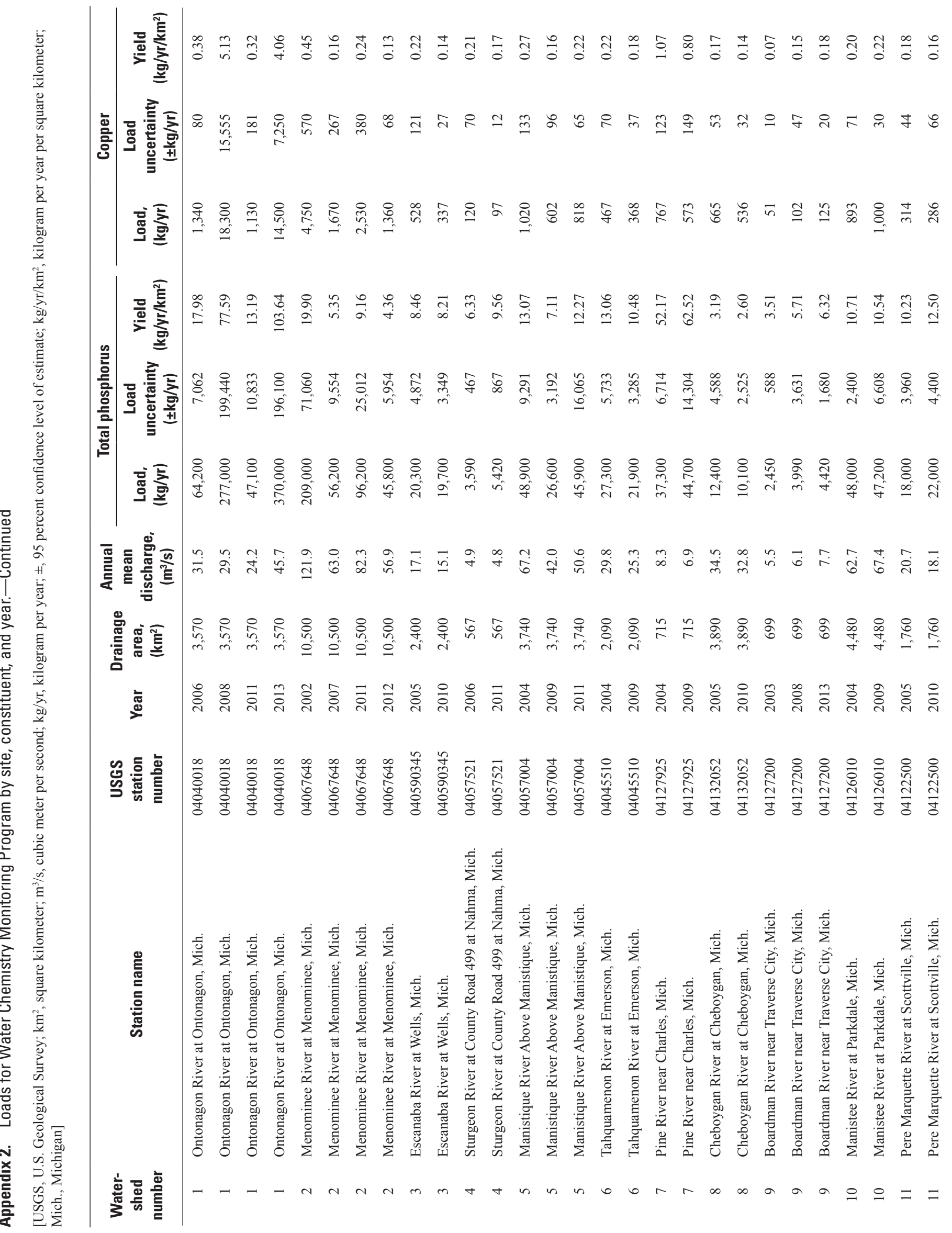




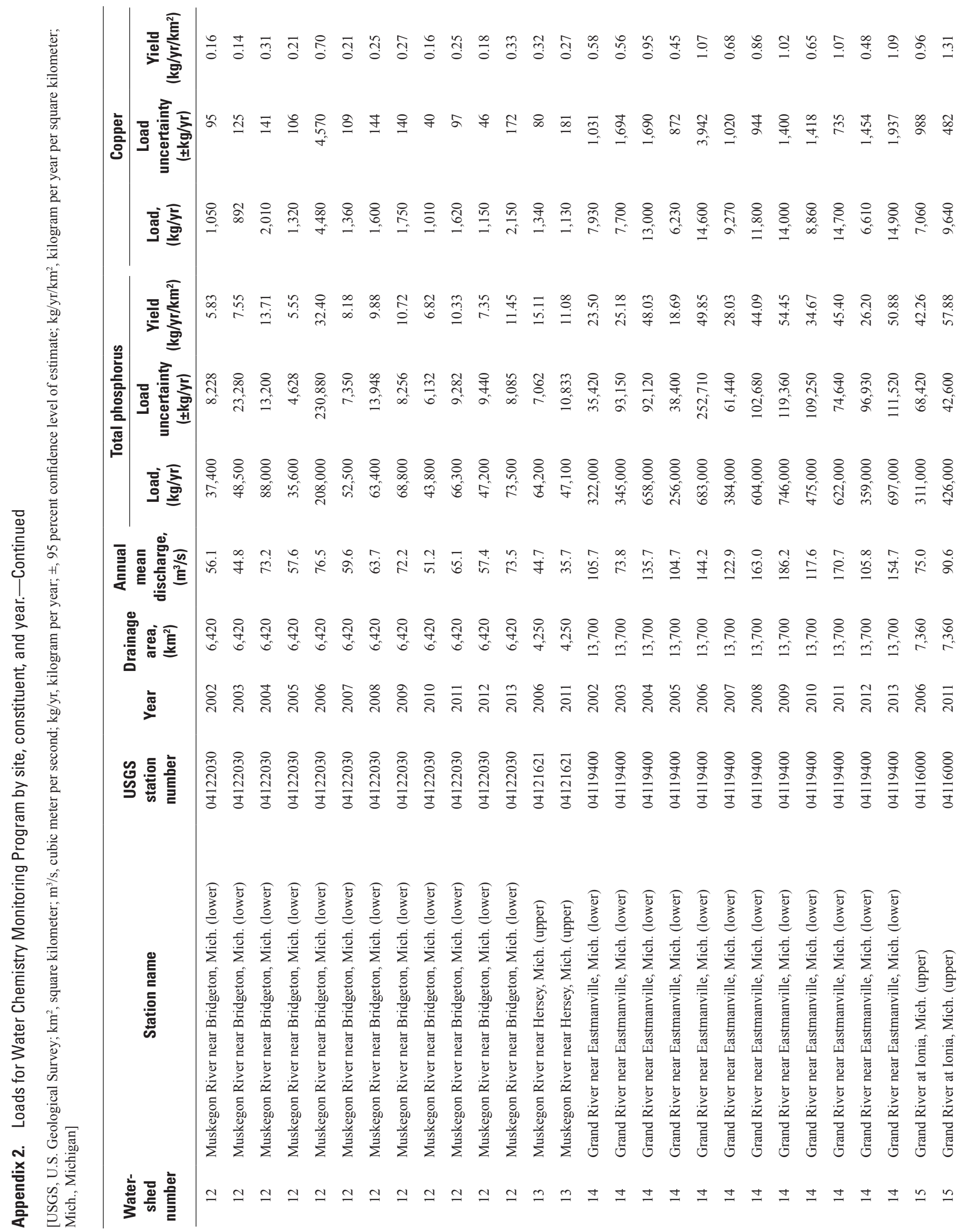




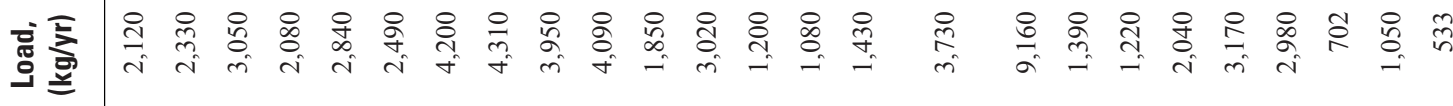

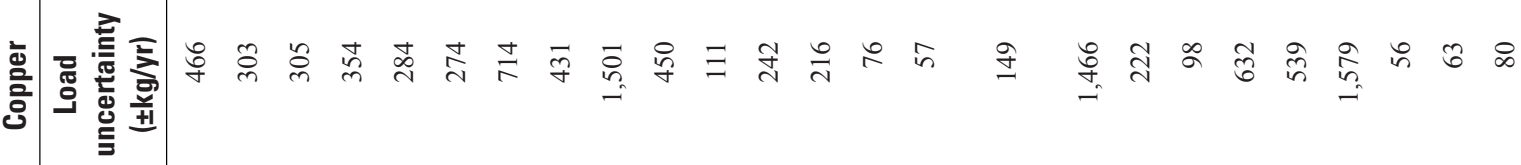

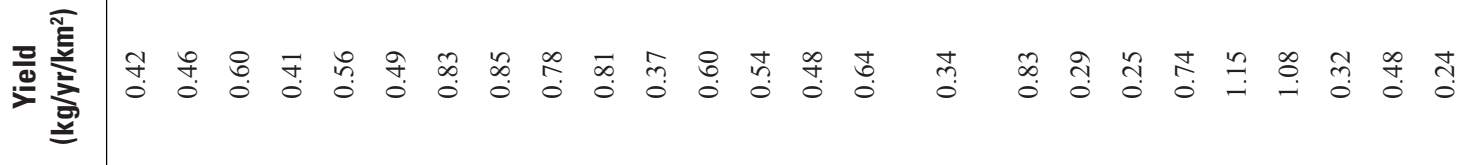

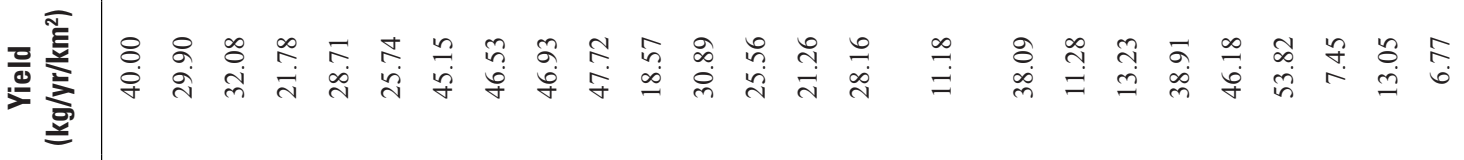

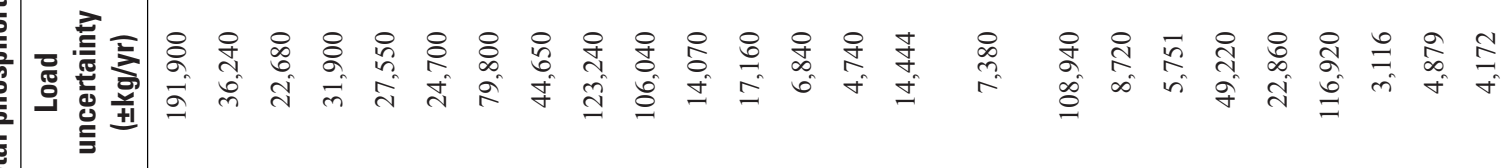

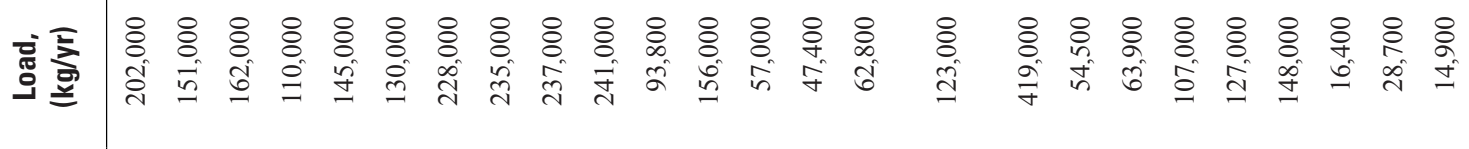

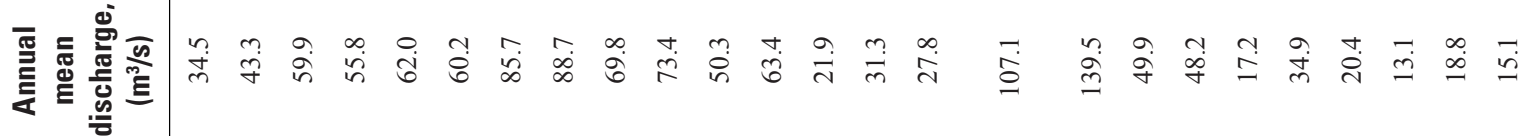

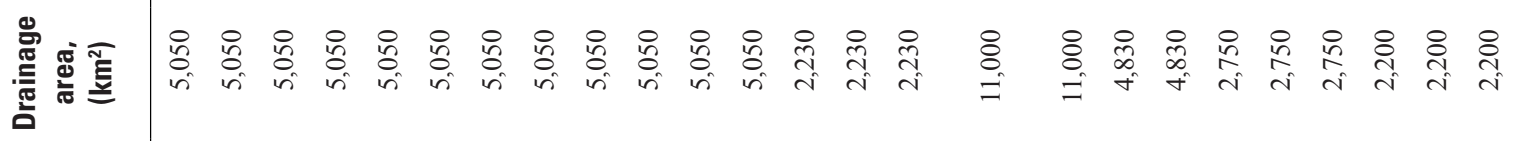

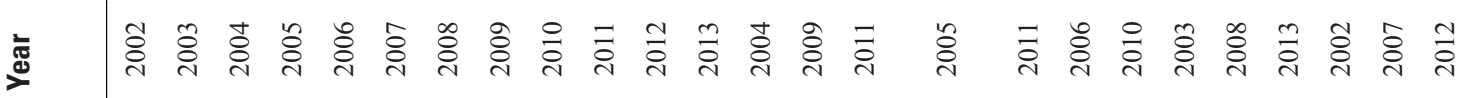

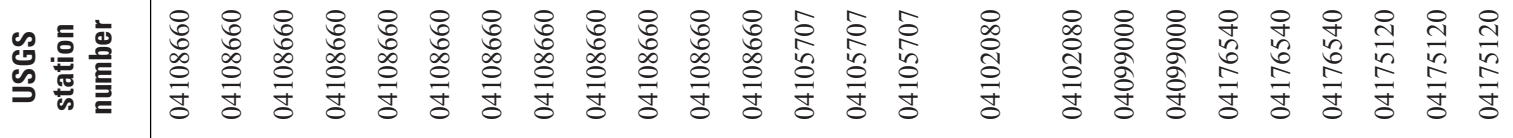

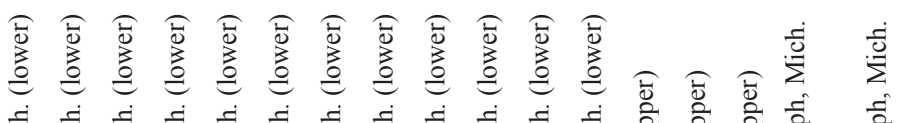

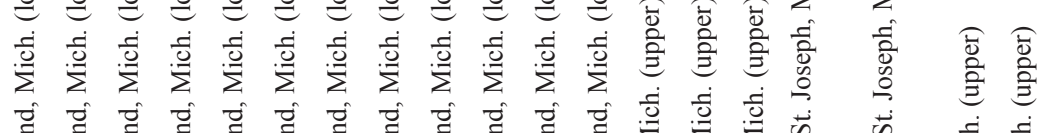

1

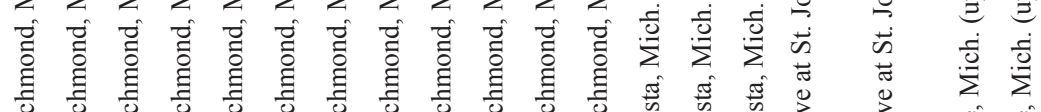

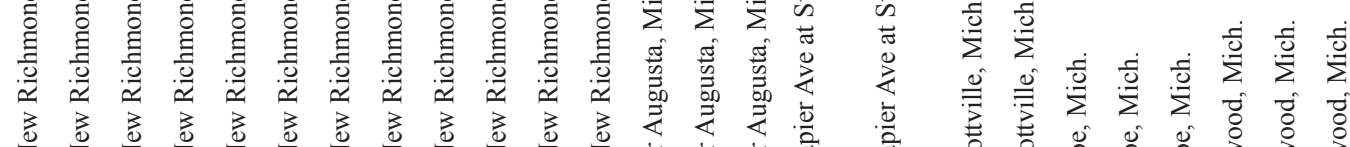

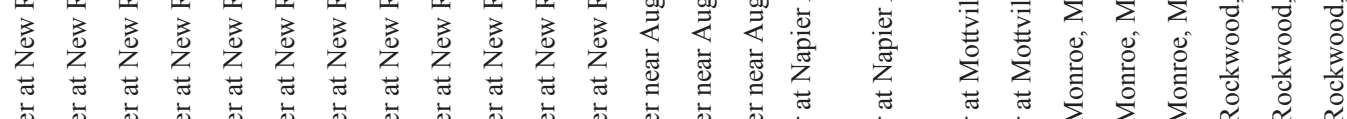

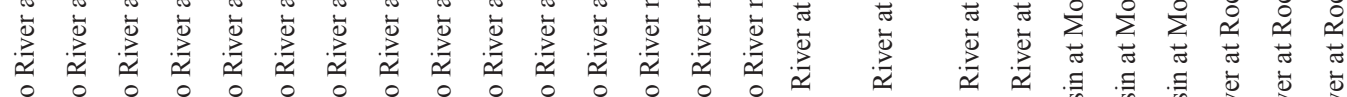

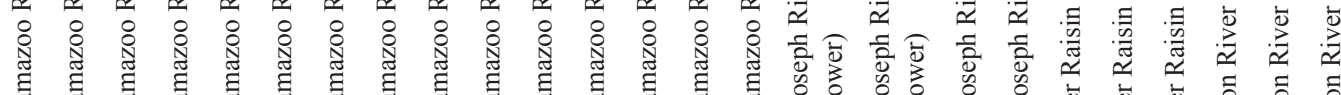

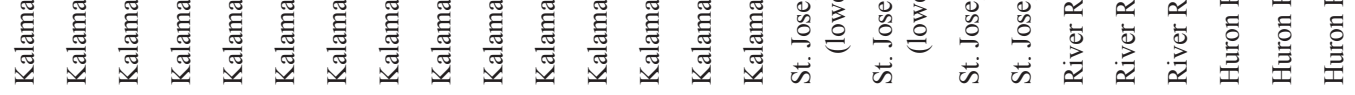

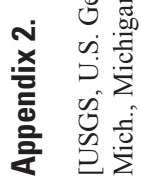

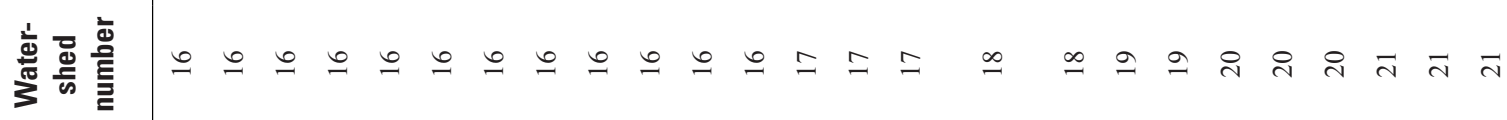




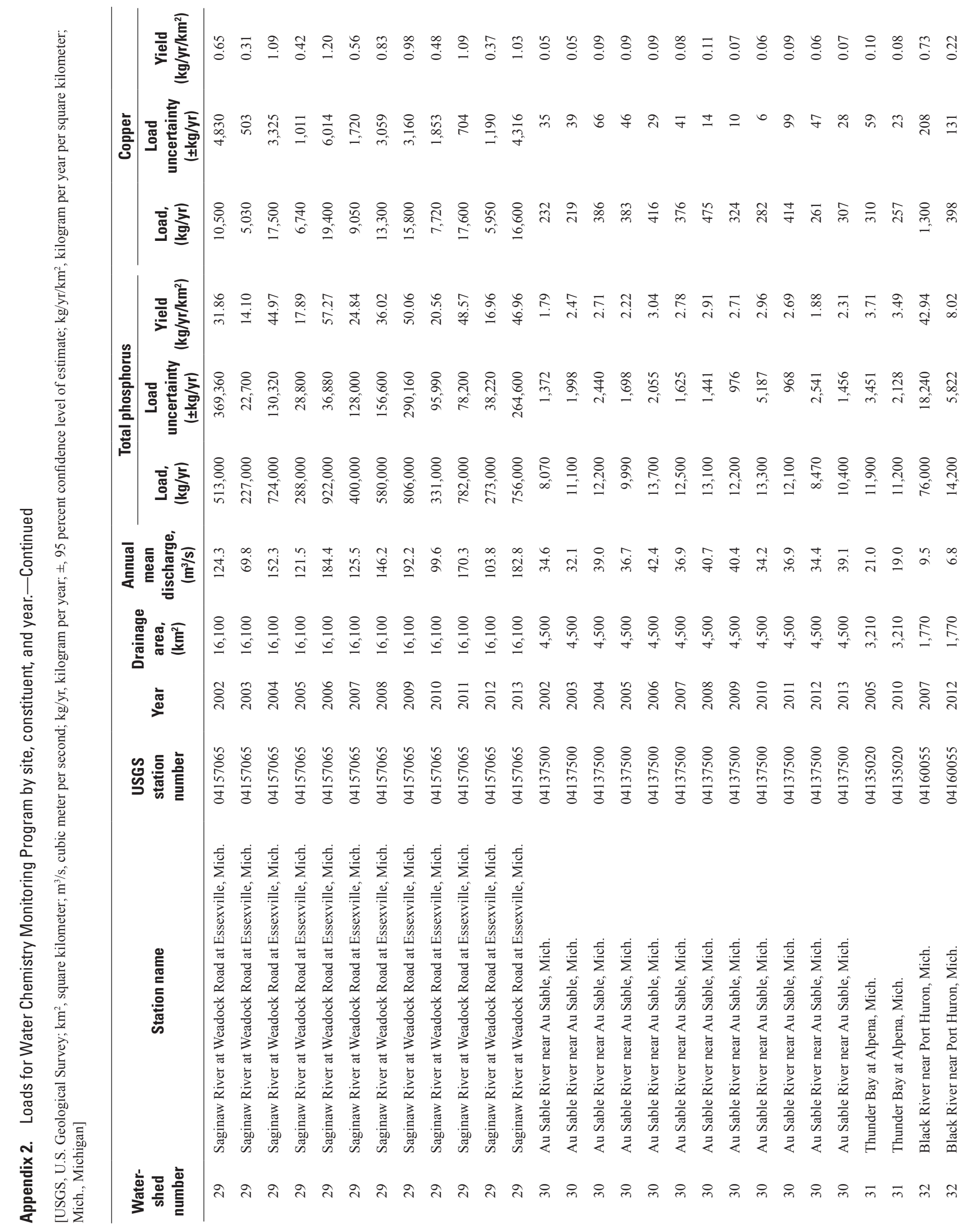




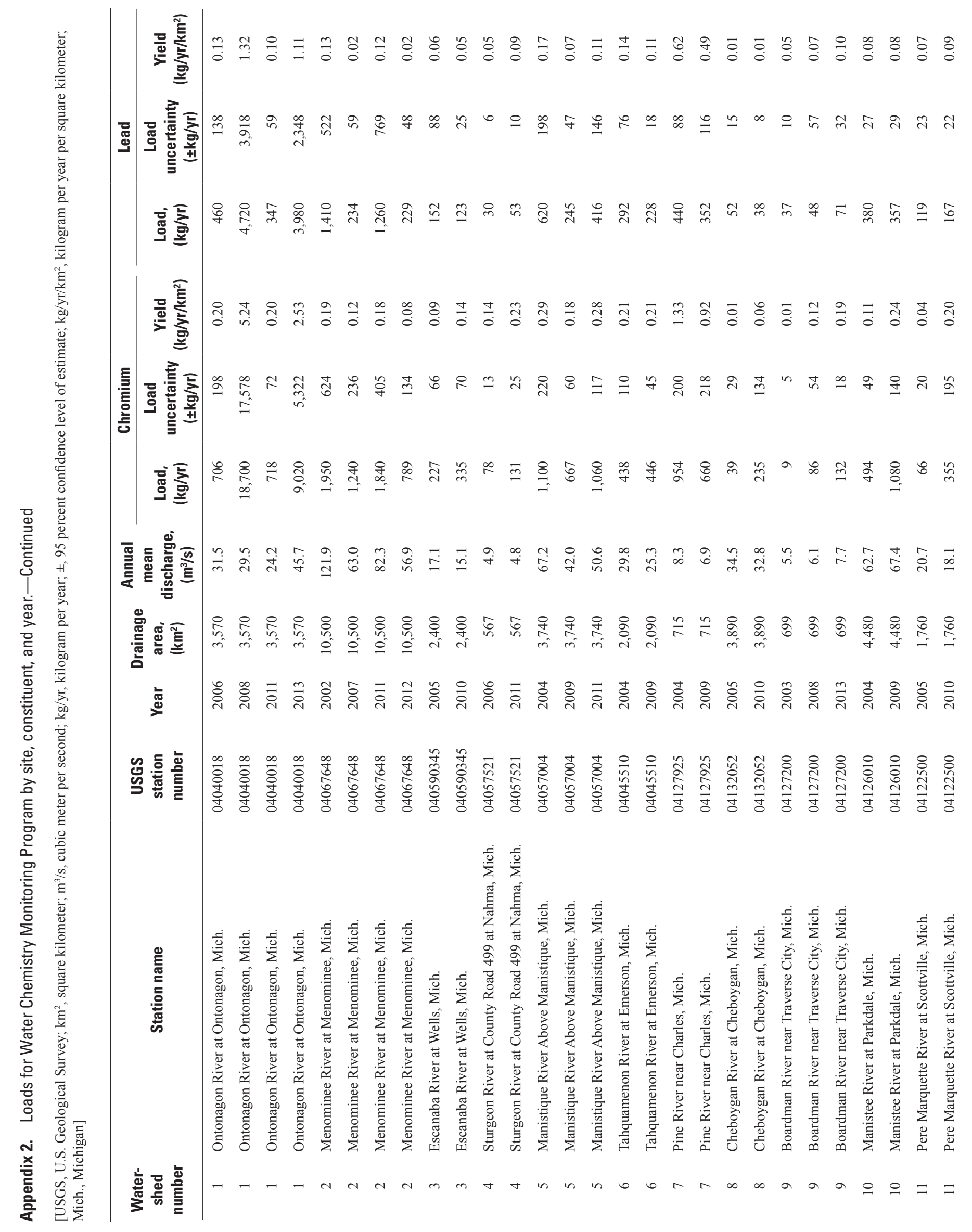




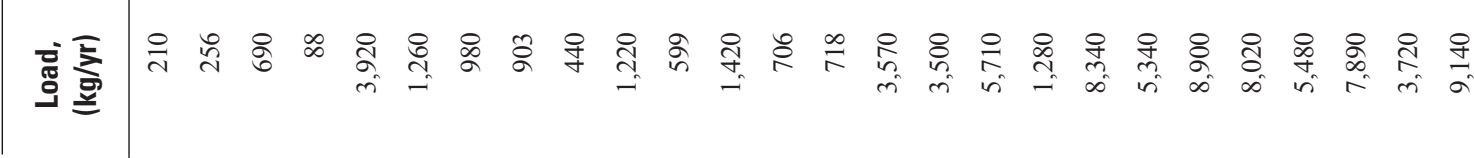

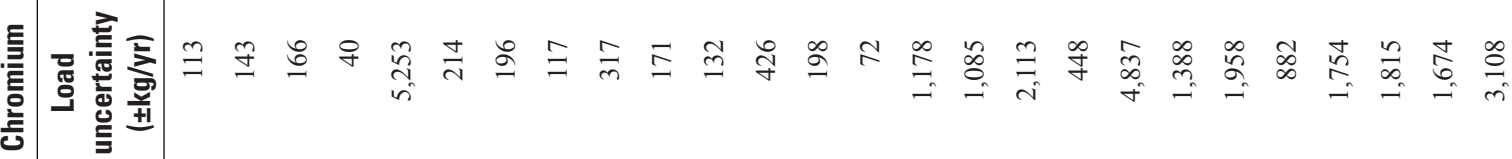

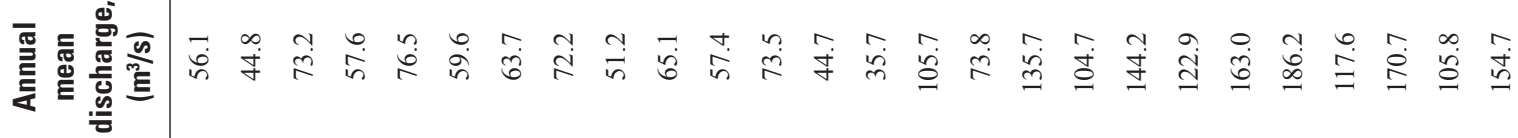

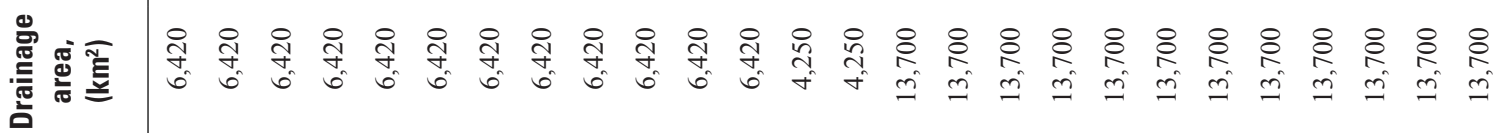

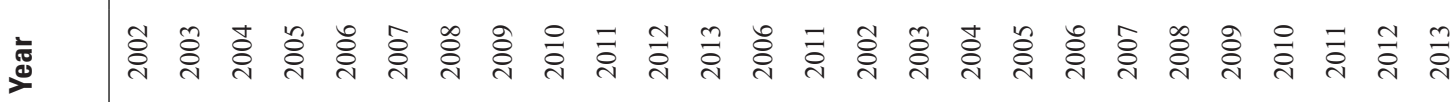

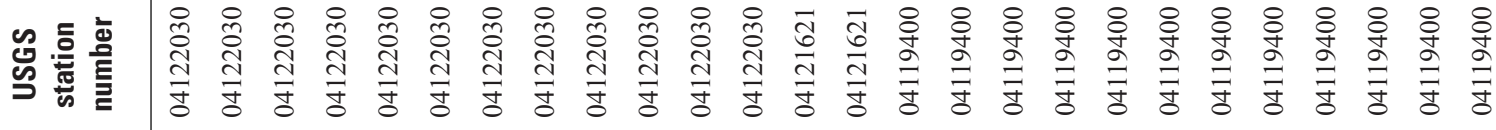

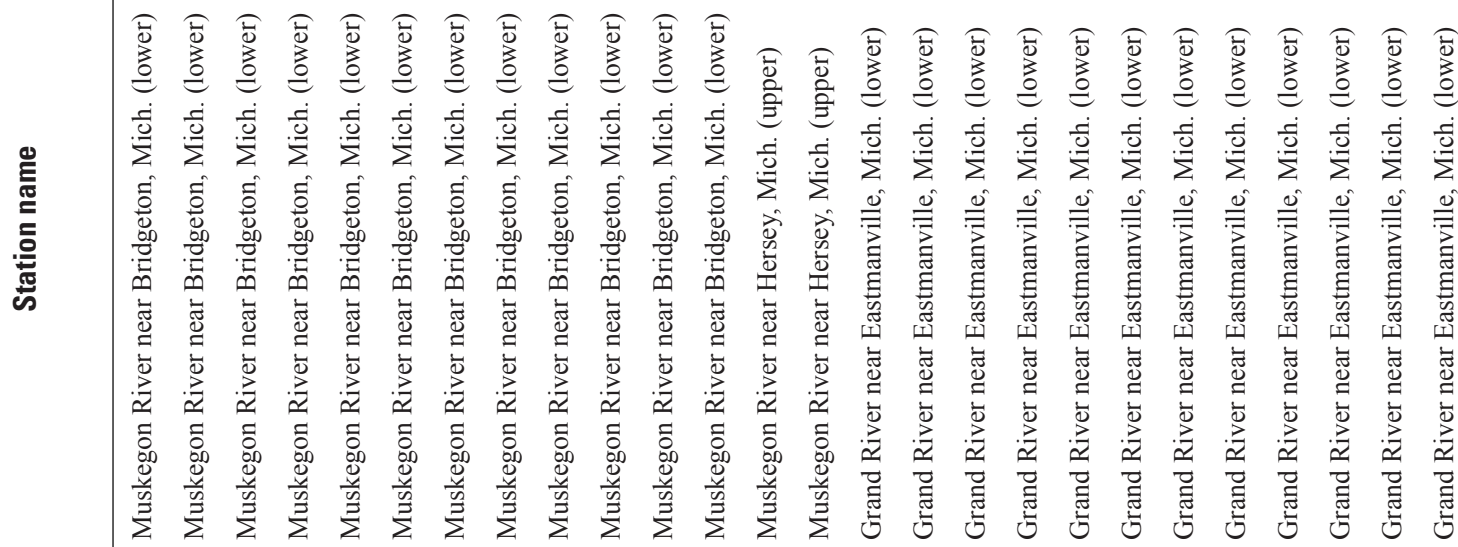

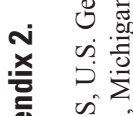




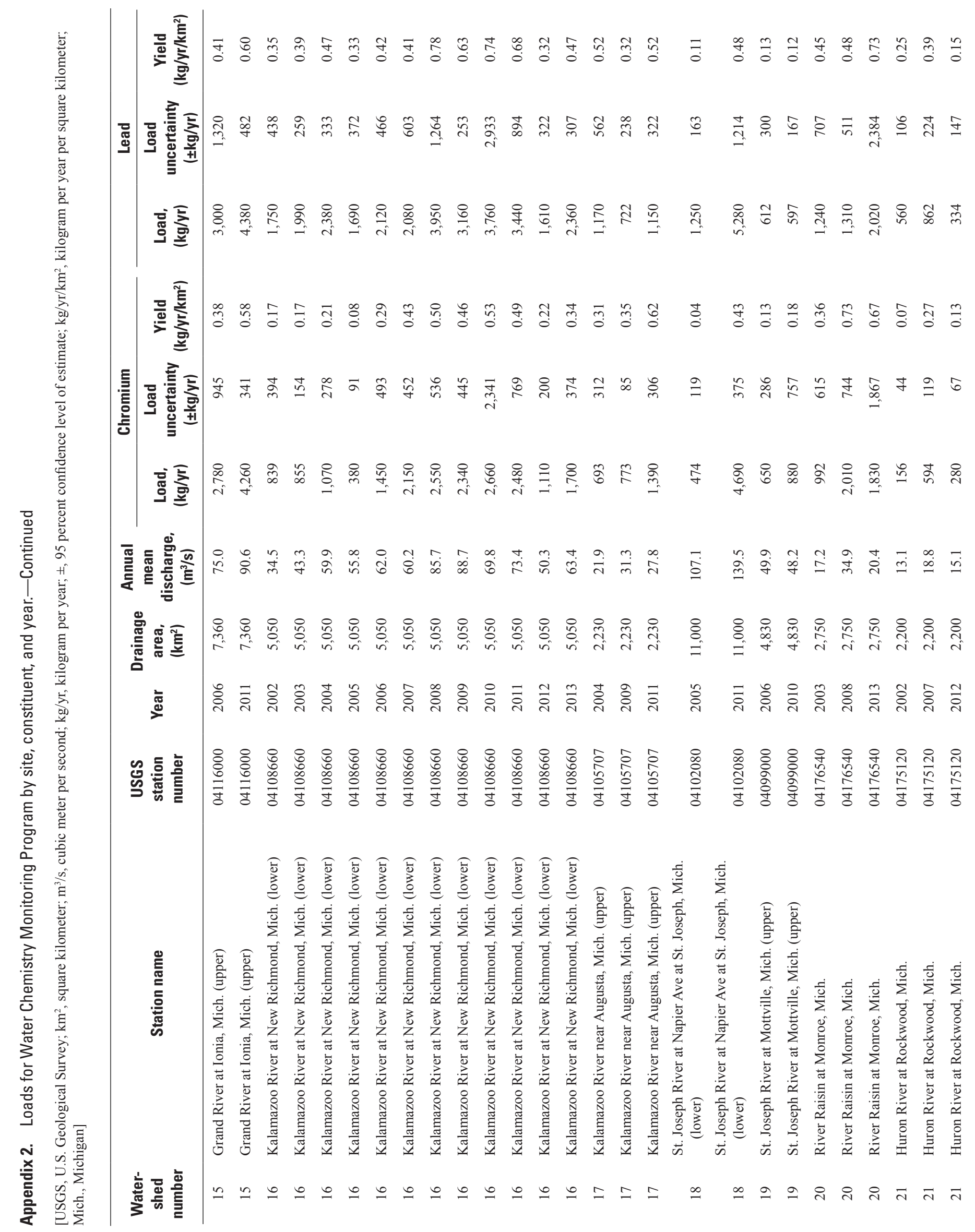




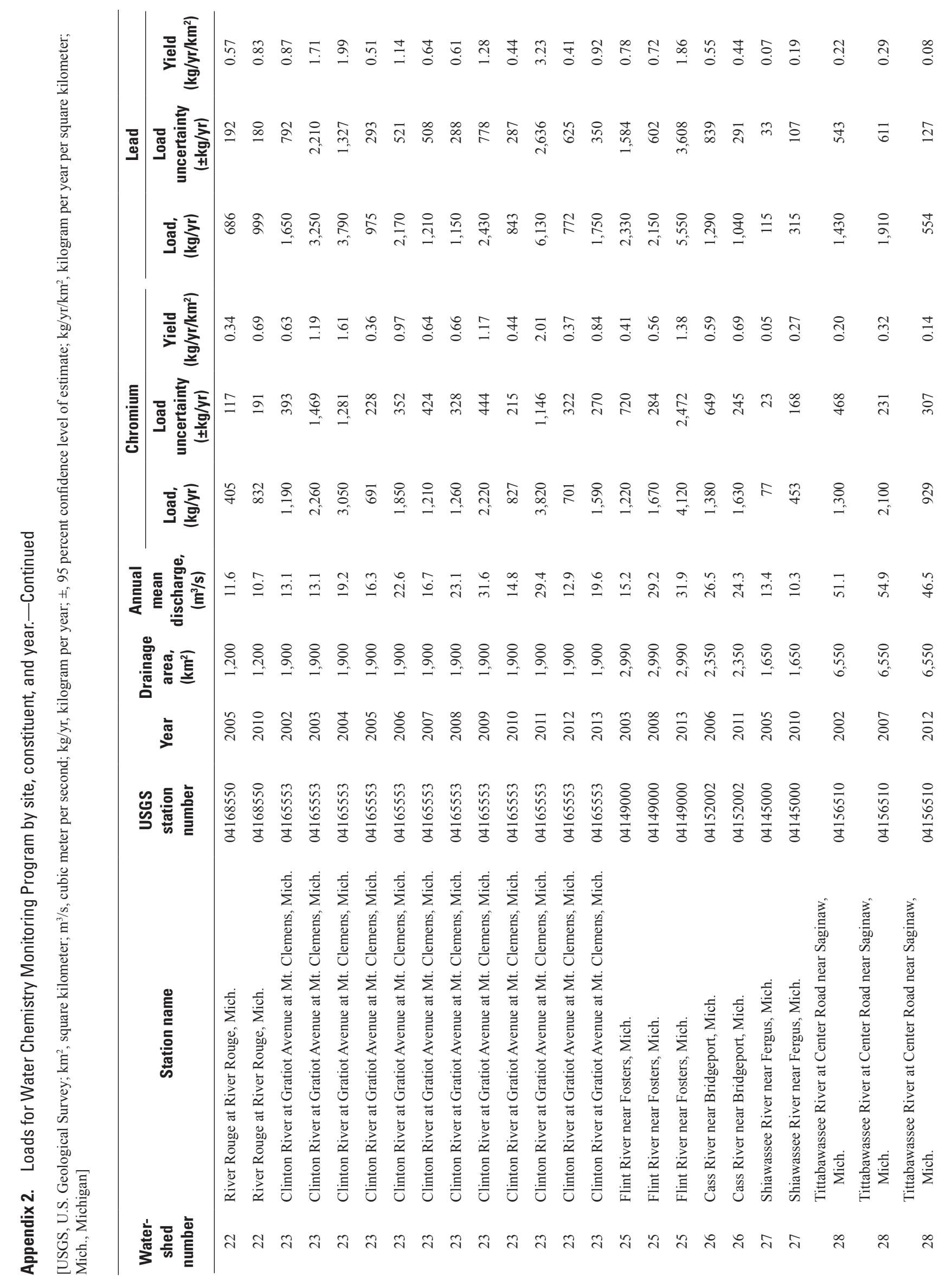




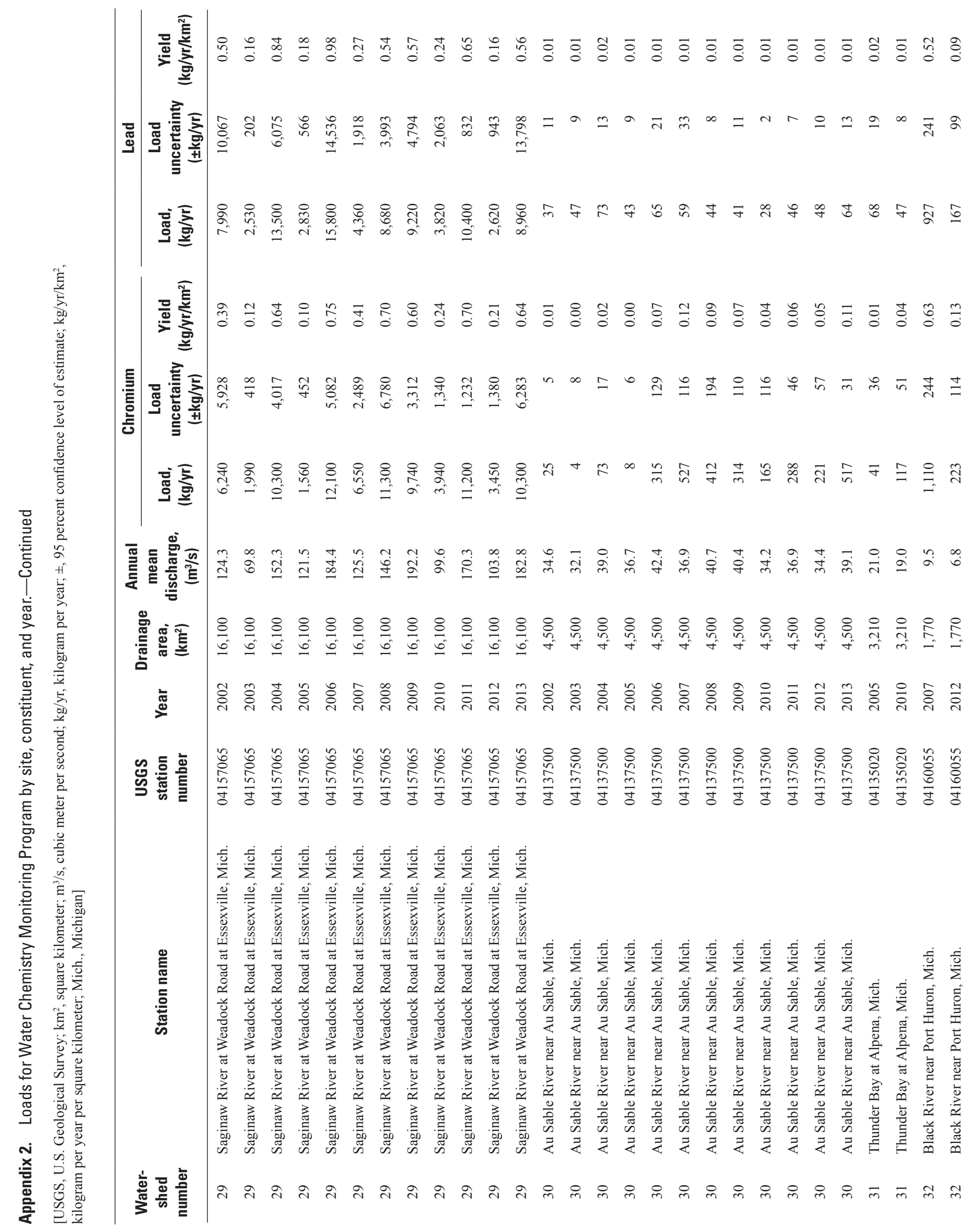




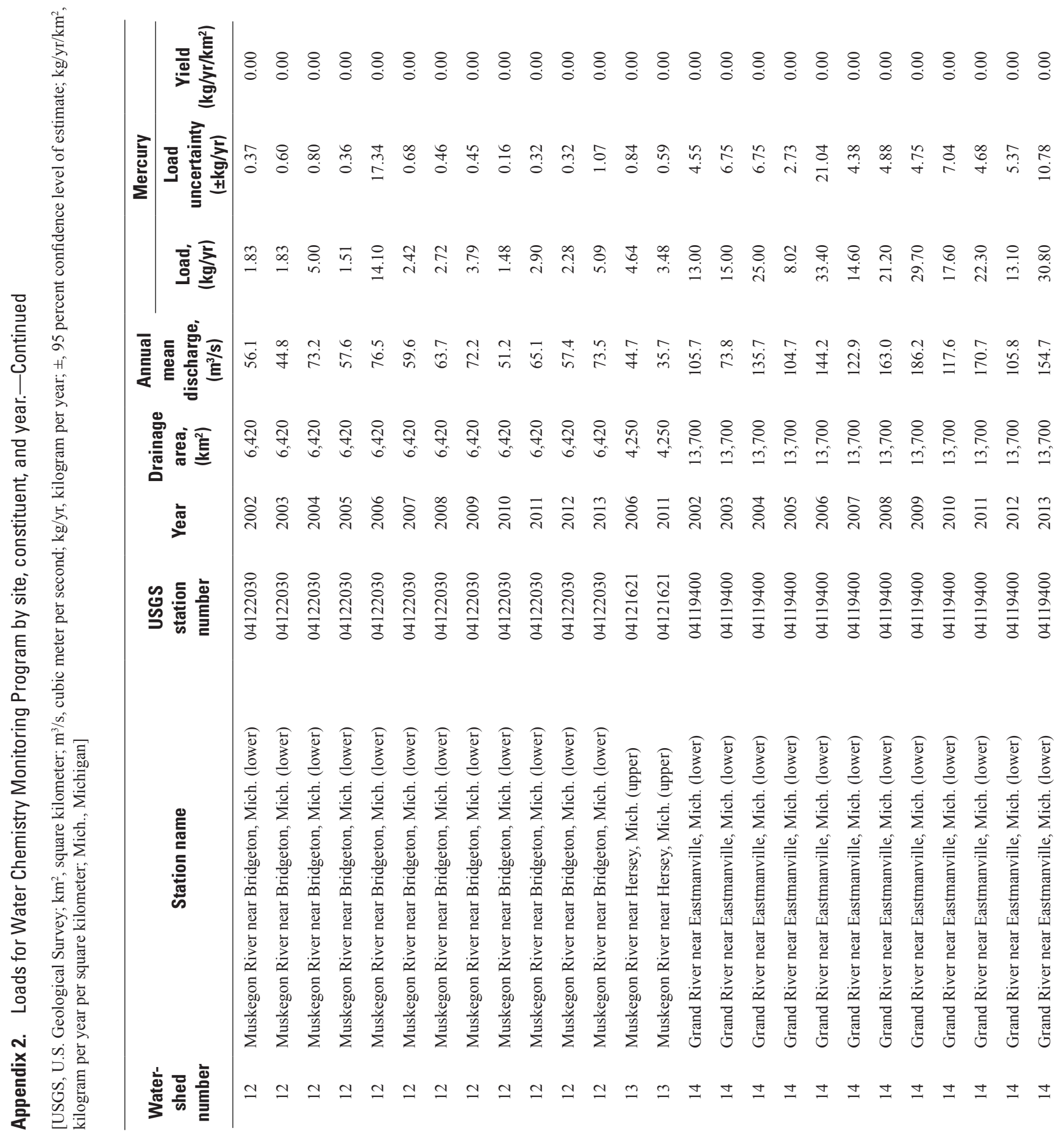


For additional information contact:

Director, Upper Midwest Water Science Center U.S. Geological Survey

6520 Mercantile Way

Suite 5

Lansing, MI 48911

(517) 887-1156

For additional information visit https://mi.water.usgs.gov/

Publishing support provided by the

Madison and Rolla Publishing Service Centers 



\section{$\frac{\mathbb{3}}{\mathbb{3}}$}

